\title{
SPATIAL DISTRIBUTION OF CORAL COMMUNITIES ON FRINGING REEFS AT TIOMAN ISLAND MARINE PARK, MALAYSIA
}

\author{
Khodzori Fikri Akmal ${ }^{a}$ and Saad Shahbudin ${ }^{\text {b* }}$
}

aBorneo Marine Research Institute, Universiti Malaysia Sabah, Sabah Port Bypass, 88400, Kota Kinabalu, Sabah, Malaysia ${ }^{b}$ Department of Marine Science, Kulliyyah of Science, International Islamic University Malaysia, Jalan Sultan Ahmad Shah, 25200, Kuantan, Pahang, Malaysia

${ }^{*}$ Corresponding author. Email: ocean@iium.edu.my

Article history

Received: 10 March 2021;

accepted 25 November 2021

\section{Keywords:}

Diversity; abundance;

scleractinian coral; Marine

Park; Peninsular Malaysia

\begin{abstract}
Monitoring coral health status is important for effective reef ecosystem management. The present study aimed to determine the coral condition and distribution at twenty sites around Tioman Island Marine Park (TIMP), Malaysia. The Coral Video Transect (CVT) method was used to survey coral, and the Coral Point Count with Excel extension (CPCe) software was used to analyse images for identification and coral coverage measurement. The findings indicate that TIMP reefs had a mean live coral cover of $48.0 \% \pm 0.7$, suggesting they were in 'fair' coral condition. A total of 254 species, spanning 61 genera and 15 families of scleractinian coral were identified across all reef sites. Following the recent taxonomic classification, coral surveys and past studies revealed 355 species from 67 genera and 15 families of scleractinian coral with additional 30 new species records for TIMP, and 15 for the east coast of Peninsular Malaysia. Overall, 29 identified scleractinian species are considered rare, 86 vulnerable, and 3 are endangered. Current data also recorded 77 genera from 24 families of hard and soft corals with Acropora, Montipora and Porites predominantly found in reef assemblages. Overall, it can be concluded that the extensive coastal development and widespread tourism activities may have influenced the variations in coral condition and distribution in this Marine Park.
\end{abstract}

\section{INTRODUCTION}

Malaysia's coral reefs cover approximately $4,000 \mathrm{~km}^{2}$, with more than $75 \%$ reef areas found along the coast of Sabah (Burke et al. 2012). In Peninsular Malaysia, coral reefs are found at several localities, including off the west coast, south coast and east coast areas. The east coast area of Peninsular Malaysia encompasses higher hard coral diversity, compared to the south coast, with 398 and 245 species identified, respectively (Affendi and Rosman 2012). Meanwhile, the west coast of Peninsular Malaysia showed the lowest coral diversity area with only 56 species identified (Affendi and Rosman 2012). The data compiled to date gives a species count of 480 hard corals in Peninsular Malaysia (Affendi and Rosman 2012). This figure represents approximately $80 \%$ of the total number of hard coral species identified in the Coral Triangle area (Veron et al. 2015).

Tioman Island Marine Park (TIMP), situated on the east coast of Peninsular Malaysia has formed the basis of a valuable Malaysian tourism industry, due to its high coral diversity (Shahbudin et al. 2017; Akmal et al. 2019). It comprises nine large islands (Chebeh, Seri Buat, Sembilang, Tioman, Tulai, Labas, Tokong Bahara, Gut and Sepoi Islands) and five small islands (Renggis, Tumok, Soyak, Tasu and Raja Islands), with approximately $69 \mathrm{~km}^{2}$ of fringing reef areas (DMPM 2011).
These areas are fully protected under the Fisheries Act 1985, with no fishing activities being permitted within two nautical miles of the Marine Park area. TIMP is also recognized as the most popular tourist destination for diving and snorkelling activities (Saad et al. 2015). Over 4.5 million tourists are estimated to have visited TIMP between 2000 and 2019, with an annual average of more than 200 thousand tourists (DMPM 2019). In addition to diverse coral species, good accommodation and well-equipped tourist facilities are promoting the inflow of local and foreign tourists (Hanim et al. 2010; Omar et al. 2015). Currently, a total of 72 coastal resorts have been developed and the majority are located along the west coast zone of Tioman Island (RCM 2018).

However, extensive coastal development and tourism activities have been reported to contribute to the low coverage of live corals at some reef sites in the west coast zone of Tioman Island (Toda et al. 2007; Shahbudin et al. 2017; Akmal et al. 2019). Additionally, a high number of tourists visiting TIMP has been linked to the excess of untreated sewage disposed directly from hotels and resorts into the reefs (RCM 2018). This is further compounded by effluent discharges from local houses into the river system, as has been recorded at the Lalang River on Tioman Island (Zakariah et al. 2007). Apart from that, the severity of the bleaching event in 2010 has been observed to cause partial mortality of ap- 
proximately $50 \%$ of live coral cover at several reef sites in the isolated zone of TIMP (Tan and Heron 2011).

Numerous studies have determined the coral condition around TIMP (e.g. Harborne et al. 2000; Affendi et al. 2005, 2007; Toda et al. 2007; Khodzori et al. 2015; Shahbudin et al. 2017; Akmal et al. 2019; Lau et al. 2019). However, few published studies determined the diversity and distribution patterns of hard and soft corals around TIMP (e.g. Saad and Khodzori 2017; Shahbudin et al. 2017; Akmal et al. 2019). Additionally, data collected from the previous studies was inadequate to represent the study area of TIMP due to a limited number of survey reef sites (e.g. Harborne et al. 2000; Affendi et al. 2005, 2007). In fact, reef sites in the east coast zone of TIMP remain undocumented, and the information on the conservation status of coral species, either rare, endangered, or vulnerable, is yet to be comprehensively determined.

Therefore, this study aimed to update the list of scleractinian hard corals, including rare, vulnerable, and endangered species. The following update of the species list is further combined with the previous datasets published by Harborne et al. (2000), Affendi et al. (2005) and Affendi et al. (2007). Based on comprehensive coral surveys at 20 reef sites around TIMP, this study also provides updated data on coral condition as well as the distribution patterns of hard and soft corals using the Coral Video Transect (CVT) method. The findings of this study would be beneficial to the section of Marine Park Malaysia, Department of Fisheries (DOF) and universities in updating the status of coral condition for the protection of reefs around TIMP. The data presented in this study can also be used to update geographical information on coral diversity and distribution in tropical reef ecosystems.

\section{MATERIALS AND METHODS}

\section{Study area}

Tioman Island, in the South China Sea $\left(02^{\circ} 48^{\prime} 52.1^{\prime \prime} \mathrm{N}\right.$ and $\left.104^{\circ} 10^{\prime} 29.3^{\prime \prime} \mathrm{E}\right)$, is the largest island on the east coast of Peninsular Malaysia, covering approximately $21 \mathrm{~km}$ in length and $12 \mathrm{~km}$ in width (Ng. et al. 1999). The island's coast is 58\% rocky headlands and cliffs, and $42 \%$ sandy beach (DMPM 2011). It is estimated about 3,200 villagers reside in nine villages, with three on the northwest coast (Salang, Air Batang and Tekek villages), four on the southeast coast (Paya, Genting, Lanting and Nipah villages), Mukut village on the south coast, and Juara village on the east coast of Tioman Island (Omar et al. 2015). Tekek is the capital village of Tioman which serves as the administrative centre of the island, providing many infrastructures and facilities including an airport, bank, marina, jetty complex, and several retail stores.
In this study, twenty reef sites were surveyed, including the east coast, west coast and isolated zones of TIMP, which exhibit different environmental settings, coastal developments and human activities that might establish a gradient of human impacts, allowing comparisons in coral condition and distribution (Figure 1). Six reef sites were surveyed in the east coast zone: Dalam Bay (TE1), Dungun Bay (TE2), Ruit Bay (TE3), Juara Bay (TE4), Benuang Bay (TE5) and Sanggit Bay (TE6). All reef sites are less visited by snorkelers and divers since they are directly facing the South China Sea and frequently exposed to strong winds and current actions. No coastal development takes place nearby to the reef sites, except at TE4. TE4 is in front of Juara Village, which is surrounded by resorts and residential sites. Meanwhile, six reef sites were surveyed in the west coast zone: Salang Bay (TW1), Soyak Bay (TW2), Renggis Island (TW3), Tomok Island (TW4), Genting Bay (TW5) and Nipah Bay (TW6). All reef sites are surrounded by a high density of resorts, chalets and residential areas. They are also known as tourist hotspots for recreational diving and snorkelling activities. In the isolated zone, spanning the north and south-west of Tioman Island (Figure 1), eight reef sites were surveyed: Gado Bay (TI1), Bayan Bay (TI2), Bakau Bay (TI3), Malang Rock (TI4), Labas Island (TI5), Chebeh Island (TI6), Tokong Rock (TI7) and Bahara Rock (TI8). There are no coastal developments near to the isolated zone reef sites. However, they are heavily used for snorkelling and deep diving activities.

\section{Coral survey method}

The Coral Video Transect (CVT) method was used with a $100 \mathrm{~m}$ transect line, with $4 \times 20 \mathrm{~m}$ segments at $5 \mathrm{~m}$ intervals, to survey coral at each of the 20 reef sites around TIMP (Liew et al. 2012; Safuan et al. 2015). An underwater camera (Olympus TG-4 in a ratio of 16:4 and $1980 \times 1080$ high definition (HD) resolution) protected with a waterproof casing (Olympus PT-053) was used to record coral images along the transect lines. The height of the camera from the substrates was approximately $50 \mathrm{~cm}$, fixed by following a reference bar and held at a perpendicular angle to the substrate. The camera was run along a transect line at a speed of 4 minutes per segment to record clear and sharp images. Additional still images of close-up coral corallites were captured to aid in the identification process. The scleractinian hard coral species were identified using the books of Corals of the World (Veron 2000) and the website of World Register of Marine Species (WoRMS).

\section{Video processing and data analysis}

The four videos recorded along each $100 \mathrm{~m}$ transect line $(n=20)$ were converted to 160 images (40 images per each $20 \mathrm{~m}$ transect segment). All images were analyzed using a Coral Point Count with Excel extension 


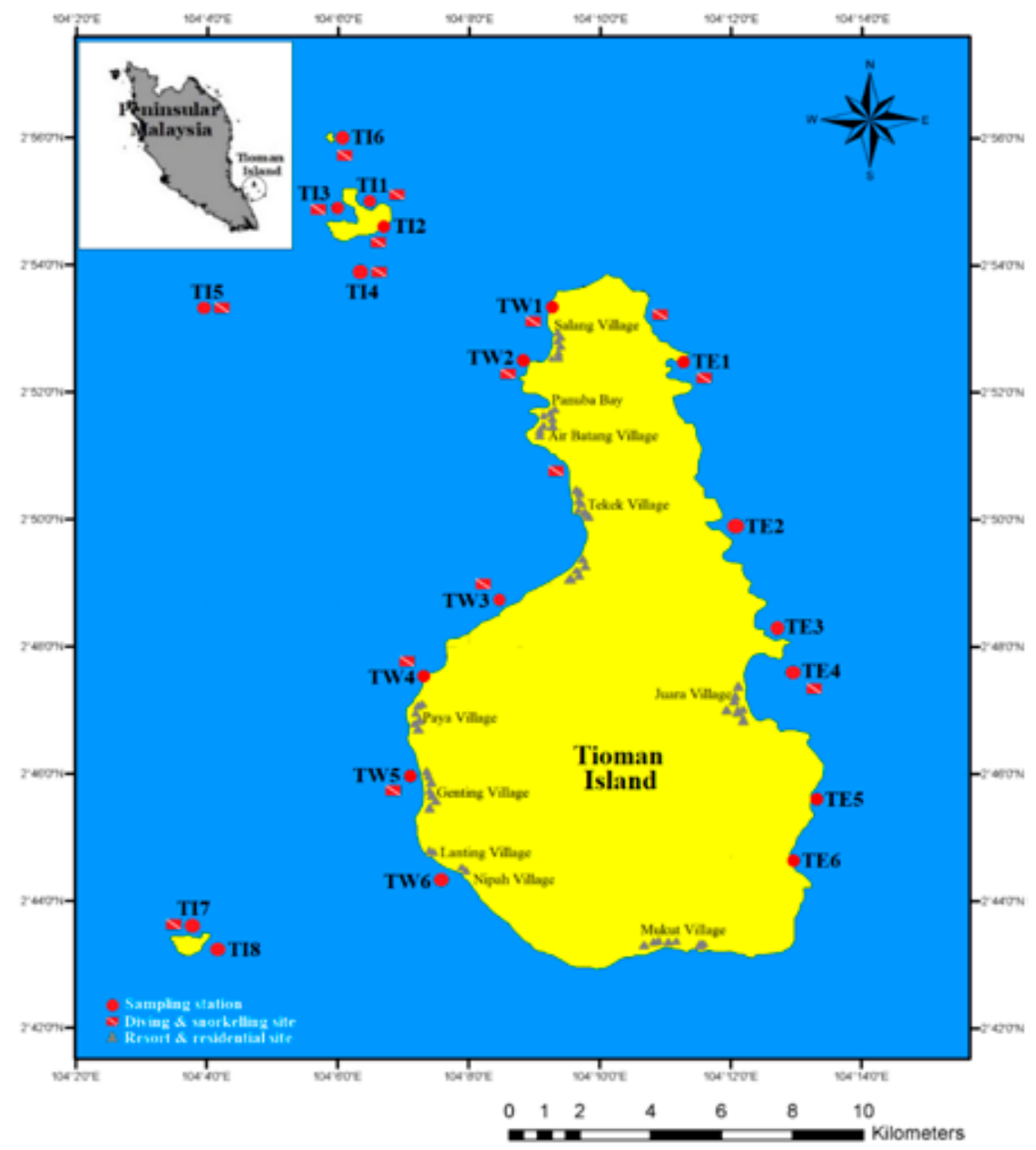

Figure 1. Locations of 20 reef sites around Tioman Island Marine Park.

(CPCe) software version 4.1 developed by Kohler and Gill (2006), with 50 uniform points per image. Data were summarized into three major categories: live corals (hard and soft corals), dead corals, and other (algae, other invertebrates, and abiotic elements). The coral condition was classified based on the mean percentage of live coral cover, following Chou et al. 1994, as either excellent $(>75 \%$ of live corals), good $(51 \%-75 \%$ of live corals $)$, fair $(26 \%-50 \%$ of live corals $)$ or poor $(<25 \%$ of live corals). A rating scale, from one to five crosses $(+)$, was used to represent the relative abundance of each coral genus, where $+=$ one or covering $<1 \%$ of coral colonies; $++=$ uncommon covering $1-5 \%$ of coral colonies; $+++=$ common covering $6-10 \%$ of coral colonies; $++++=$ abundant covering $11-20 \%$ of coral colonies; and $+++++=$ dominant covering $>20 \%$ of coral colonies, as used by Fabricius and McCorry (2006).

\section{Statistical analysis}

Kolmogorov-Smirnov (Lilliefors 1967) and ShapiroWilk (Shapiro and Francia 1972) tests indicated normally distributed data. Therefore, the difference in the mean percentage cover of benthic categories among reef sites and zones was tested using One-way Analysis of Variance (ANOVA) followed by Post-hoc Tukey HSD tests. The cluster analysis of coral taxa was performed to determine the group of similarities for all reef sites, using normalized data with $\log (\mathrm{x}+1)$ transform function and Bray Curtis method (Bray and Curtis 1957). A non-metric multidimensional scale (nMDS) plot was then used to illustrate the group of similarities for all reef sites from data interactions derived by the cluster analysis. Additionally, the similarity percentage (SIMPER) analysis was used to determine the mean similarity within all taxonomic coral compositions between different groups, as illustrated from the nMDS plot. All analyses were conducted using PAST software ver. 3 (Hammer et al. 2001).

\section{RESULTS}

Mean percentage cover of live corals and coral condition

The mean percentage of live coral cover varied significantly among the 20 reef sites $\left(\mathrm{F}_{19,60}=6.75, p=0.001\right)$, as did the percentage of other invertebrates $\left(\mathrm{F}_{19,60}=\right.$ 
4.47, $p=0.002$ ). The Post-hoc test indicated that the mean percentage cover of live coral, which ranged from approximately $25.0 \%$ at TE4 to $73.0 \%$ at TI6, was significantly higher at reef sites in the east coast zone (e.g. TE1, TE3, TE5 and TE6) and some reef sites in the west coast (TW2 and TW3) and isolated (TI1, TI4 and TI6) zones (Table 1). Meanwhile, the mean percentage cover of other invertebrates ranged from approximately $6.2 \%$ at TW 2 to $41.2 \%$ at TW6 and was significantly higher at TW6 compared to TE1, TW1, TW2, TW3, TW5, TI1, TI2, TI6, TI7 and TI8. No significant difference was observed for the dead coral cover among reef sites $\left(\mathrm{F}_{19,60}=14.08, p=0.577\right)$, though the highest was recorded at TI7 $(57.6 \% \pm 4.3)$, followed by TE4 $(52.5 \% \pm 2.8)$ and TW5 $(52.4 \% \pm 4.4)$.

The mean percentage of live coral cover $\left(\mathrm{F}_{2,9}=10.85\right.$, $p=0.004)$ and dead coral $\left(\mathrm{F}_{2,9}=16.37, p=0.001\right)$ differed significantly among the three categorized zones. The Post-hoc test indicated that the mean percentage of live coral cover on the east coast $(51.4 \% \pm 0.8)$ and isolated zone $(49.0 \% \pm 1.9)$ was significantly higher compared to the west coast $(43.3 \% \pm 0.6)$ zones. The mean percentage cover of dead coral was significantly higher in the west coast $(38.9 \% \pm 1.1)$ compared to the isolated $(34.7 \% \pm 5.0)$ and east coast $(27.3 \% \pm$ $1.0)$ zones. There was no significant difference in the mean percentage cover of other invertebrates among the zones $\left(\mathrm{F}_{2,9}=2.10, p=0.178\right)$, though the east coast zone had the highest cover at $21.6 \% \pm 0.6$. Overall, the results showed that TIMP reefs were categorized as being in 'fair' coral condition with the live coral cover of $48.0 \% \pm 0.7$. Most reef sites in the east coast zone were categorized as being in 'good' coral condition, while the west coast zone was in 'fair' coral condition. In the isolated zone, the reef sites varied between 'fair' to 'good' coral condition.

\section{Checklist of scleractinian hard coral species}

Based on recent taxonomic classification of the Scleractinia, the TIMP coral surveys recorded 254 scleractinian coral species from 61 genera and 15 families (including 6 species and 4 genera of Incertae sedis) (Supplementary Table 1). TE5 had the highest number of scleractinian corals with 155 species, followed by TE1 (138 species) and TE3 (129 species). These reef sites also harboured a higher number of scleractinian species compared to other reef sites (TE2, TE2 and TE6) in the east coast zone. In the west coast zone, TW1 had the highest number

Table 1. Mean percentage cover $(\% \pm \mathrm{SE})$ of three benthic categories and coral condition at 20 reef sites and 3 zones around TIMP.

\begin{tabular}{|c|c|c|c|c|c|c|}
\hline No. & & Reef sites & Live coral (\%) & Dead coral $(\%)$ & Other invertebrates $(\%)$ & Coral condition \\
\hline & \multicolumn{6}{|c|}{ East coast zone } \\
\hline 1 & TE1 & Dalam Bay & $56.0 \pm 3.2^{\mathrm{a}}$ & $28.4 \pm 2.4$ & $15.6 \pm 2.1^{\mathrm{b}}$ & Good \\
\hline 2 & TE2 & Dungun Bay & $53.7 \pm 2.0$ & $18.7 \pm 2.6$ & $27.7 \pm 1.6$ & Good \\
\hline 3 & TE3 & Ruit Bay & $57.9 \pm 3.0^{\mathrm{a}}$ & $22.0 \pm 1.2$ & $20.1 \pm 1.9$ & Good \\
\hline 4 & TE4 & Juara Bay & $25.0 \pm 8.2^{b}$ & $52.5 \pm 2.8$ & $23.4 \pm 4.9$ & Fair \\
\hline 5 & TE5 & Benuang Bay & $56.9 \pm 3.0^{\mathrm{a}}$ & $28.1 \pm 2.4$ & $16.8 \pm 4.1$ & Good \\
\hline \multirow[t]{3}{*}{6} & TE6 & Sanggit Bay & $59.8 \pm 1.6^{\mathrm{a}}$ & $14.3 \pm 1.0$ & $25.9 \pm 2.4$ & Good \\
\hline & \multicolumn{2}{|c|}{ Mean \pm SE } & $51.4 \pm 0.8^{\mathrm{a}}$ & $27.3 \pm 1.0^{\mathrm{b}}$ & $21.6 \pm 0.6$ & Good \\
\hline & \multicolumn{6}{|c|}{ West coast zone } \\
\hline 7 & TW1 & Salang Bay & $40.5 \pm 1.4$ & $46.4 \pm 2.6$ & $13.1 \pm 2.0^{\mathrm{b}}$ & Fair \\
\hline 8 & TW2 & Soyak Island & $66.0 \pm 2.2^{\mathrm{a}}$ & $27.8 \pm 1.4$ & $6.2 \pm 1.5^{\mathrm{b}}$ & Good \\
\hline 9 & TW3 & Renggis Island & $45.6 \pm 3.4^{\mathrm{a}}$ & $40.3 \pm 4.9$ & $14.2 \pm 1.9^{\mathrm{b}}$ & Fair \\
\hline 10 & TW4 & Tomok Island & $31.0 \pm 8.7$ & $45.9 \pm 3.2$ & $23.1 \pm 10.4$ & Fair \\
\hline 11 & TW5 & Genting Bay & $38.3 \pm 4.4$ & $52.4 \pm 4.4$ & $9.4 \pm 2.4^{b}$ & Fair \\
\hline \multirow[t]{3}{*}{12} & TW6 & Nipah Bay & $38.3 \pm 9.1$ & $20.5 \pm 2.2$ & $41.2 \pm 9.3^{\mathrm{a}}$ & Fair \\
\hline & \multicolumn{2}{|c|}{ Mean \pm SE } & $43.3 \pm 0.6^{\mathrm{b}}$ & $38.9 \pm 1.1^{\mathrm{a}}$ & $17.9 \pm 1.7$ & Fair \\
\hline & \multicolumn{6}{|c|}{ Isolated zone } \\
\hline 13 & TI1 & Gado Bay & $59.7 \pm 4.1^{\mathrm{a}}$ & $31.5 \pm 4.1$ & $8.8 \pm 1.2^{b}$ & Good \\
\hline 14 & TI2 & Bayan Bay & $49.5 \pm 8.1$ & $43.2 \pm 6.5$ & $7.3 \pm 1.7^{b}$ & Fair \\
\hline 15 & TI3 & Bakau Bay & $27.6 \pm 3.6^{b}$ & $41.4 \pm 4.4$ & $30.9 \pm 7.4$ & Fair \\
\hline 16 & TI4 & Malang Rock & $55.0 \pm 6.6^{\mathrm{a}}$ & $24.2 \pm 4.1$ & $20.8 \pm 8.9$ & Good \\
\hline 17 & TI5 & Labas Island & $42.4 \pm 3.8$ & $21.8 \pm 0.8$ & $35.9 \pm 4.3$ & Fair \\
\hline 18 & TI6 & Chebeh Island & $73.0 \pm 2.6^{\mathrm{a}}$ & $14.6 \pm 2.5$ & $12.4 \pm 2.2^{b}$ & Good \\
\hline 19 & TI7 & Tokong Rock & $34.9 \pm 6.2$ & $57.6 \pm 4.3$ & $7.5 \pm 2.0^{\mathrm{b}}$ & Fair \\
\hline \multirow[t]{3}{*}{20} & TI8 & Bahara Rock & $48.0 \pm 0.7$ & $33.9 \pm 1.4$ & $13.9 \pm 2.3^{\mathrm{b}}$ & Fair \\
\hline & \multicolumn{2}{|c|}{ Mean \pm SE } & $49.0 \pm 1.9^{\mathrm{a}}$ & $34.7 \pm 5.0^{\mathrm{b}}$ & $17.2 \pm 2.2$ & Fair \\
\hline & \multicolumn{2}{|c|}{ Tioman island } & $48.0 \pm 0.7$ & $33.4 \pm 1.4$ & $18.7 \pm 3.7$ & Fair \\
\hline
\end{tabular}

Note: Superscripts a and b indicate significant level $(p<0.05)$ based on Post-hoc Tukey HSD test. 
of scleractinian corals with 122 species. In the isolated zone, TI2 (112 species) and TI1 (111 species) had the highest number of scleractinian species compared to other reef sites (TI3, TI4, TI5, TI6, TI7 and TI8). A low number of scleractinian species was recorded at TI7 (33 species) and TW6 (35 species), located in the isolated and west coast zones, respectively. Among the 254 recorded scleractinian species, 19 species were considered the most common and recorded at most reef sites $(\mathrm{n} \geq 17)$ while 94 species were the least common and were recorded at a few sites $(\mathrm{n} \leq 3)$. Previous scleractinian coral species lists for TIMP presented by Harborne et al. (2000) recorded 157 scleractinian species at seven reef sites (Batu Malang, Tlk. Juara, Pulau Gut, Pulau Tokong Bahara, Pulau Seri Buat, Tlk. Kadar at Pulau Tulai and Pulau Renggis). The additional coral surveys done by Affendi et al. (2005) at Tlk. Tekek and by Affendi et al. (2007) at several reef sites from Kg. Paya to Kg. Genting recorded 204 species and 248 species, respectively. Therefore, in comparison to all studies above, the present checklist revealed a total of 355 species from 67 genera and 15 families (including 8 species from 5 genera of Incertae sedis) of the scleractinian hard corals in TIMP (Table 2). There were 30 new scleractinian species records for Tioman Island, of which 15 were also new records for the east coast of Peninsular Malaysia. The surveys also documented 29 rare coral species, 86 vulnerable and three endangered (Supplementary Table 2).

\section{Mean percentage cover, diversity and distribution} patterns of coral

A total of 77 coral genera from 24 families were recorded in TIMP. Out of these 77 genera, 61 were identified as scleractinian hard corals, three were non-scleractinian hard corals and 13 were soft corals (Table 2). Family Acroporidae had the highest mean percentage of coral cover at $35.0 \% \pm 3.7$, followed by Merulinidae $(20.9 \% \pm$ $0.4)$, Poritidae $(12.7 \% \pm 6.0)$, Alcyoniidae $(5.7 \% \pm 0.6)$, Euphylliidae $(5.40 \% \pm 0.97)$, Pocilloporidae $(4.77 \%$ $\pm 2.29)$, Fungiidae (4.27 \pm 0.18$)$ and Lobophylliidae (3.52 \pm 0.47$)$. Coral cover for other families was $<5 \%$. In terms of the coral genera, Acropora had the highest mean percentage of coral cover with $21.0 \% \pm 2.3$, followed by Porites $(12.3 \% \pm 2.3)$, Montipora $(9.3 \% \pm$ 2.0), Goniastrea $(5.4 \% \pm 1.0)$, Pocillopora $(4.7 \% \pm 1.5)$, Platygyra (4.6\% \pm 0.7$)$, Galaxea $(3.7 \% \pm 0.7)$, Isopora $(4.0 \% \pm 2.3)$, Dipsastraea $(3.3 \% \pm 0.6)$, Lobophyllia $(3.1 \% \pm 0.5)$, Favites $(3.0 \% \pm 0.6)$ and Sinularia $(3.0 \%$ \pm 0.6 ), while other genera cover was $<3 \%$.

The number of crosses (+) in Table 2 represents the relative abundance of coral genera based on the range of the mean percentage cover of an individual coral genus. Genera Acropora, Montipora, Galaxea, Lobophyllia,
Dipsastraea, Goniastrea, Platygyra, Pocillopora and Porites were recorded at all reef sites. Among these genera, Acropora, Montipora and Porites were abundant to dominant at most reef sites in the study area. The genera Isopora and Pocillopora were dominant at TW5 and TW6, respectively. Other genera, such as Pavona, Galaxea, Fungia, Goniastrea, Platygyra and Nepthea, were abundant at some reef sites in the east coast and isolated zones, while genera Galaxea, Lobophyllia, Dipsastraea, Favites, Goniastrea, Platygyra and Sinularia were common at most reef sites in the east coast zone. There are 22 coral genera classified as the least common, namely Alveopora, Coeloseris, Leptoseris, Stylocoeniella, Danafungia, Heliofungia, Lobactis, Podabacia, Homophyllia, Oxypora, Pectinia, Scapophyllia, Trachyphyllia, Pseudosiderastrea, Physogyra, Distichipora, Klyxum, Scleronephthya, Dichotella, Clavularia, Xenia and Acanthogorgia, and they can be found at three or less reef sites $(\mathrm{n} \leq 3)$ in TIMP. Among these 22 genera, 8 genera from Homophyllia, Oxypora, Scapophyllia, Trachyphyllia, Pseudosiderastrea, Distichipora, Xenia and Acanthogorgia were classified as rare, as they were found in low abundance at only one reef site.

\section{Coral genera composition in reef assemblages}

The results of the cluster and nMDS plot revealed six groups (G1-G6) represented by five different dominant coral genera (Figure 2). SIMPER analysis (Figure 3) indicated that genus Acropora was the most dominant in G1, G2, G4 and G5, with the mean percentage of coral cover ranging from $15.2 \% \pm 1.5$ to $40.5 \% \pm 5.8$. Meanwhile, Porites $(34.0 \% \pm 9.2)$ and Isopora $(42.9 \%$ \pm 8.9 ) were the most dominant coral genera in G3 and G6, respectively. Other genera, such as Fungia $(10.8 \% \pm$ $3.5)$, Pocillopora $(32.1 \% \pm 11.1)$ and Montipora $(16.4 \%$ \pm 2.9 ), were recorded as the second most dominant corals in G1, G4 and G5, respectively. SIMPER analysis also showed that several hard coral genera (Platygyra, Goniastrea, Lobophyllia, Pavona and Dipsastraea) and soft coral genera (Nepthea and Sinularia) were among the most dominant within the six different groups.

The cluster and nMDS plot also indicated that all reef sites in the east coast (TE1-TE6), two reef sites in the isolated (TI1 and TI2) and TW1 in the west coast zones were in G2, which was dominated by genera Acropora, Porites, Montipora, Platygyra and Sinularia. In comparison, most reef sites in the isolated (TI4, TI6, TI7 and TI8) and two reef sites in the west coast (TW2 and TW3) zones were in G5, dominated by genera Acropora, Montipora, Porites, Pavona and Pocillopora. Other reef sites in the west coast and isolated zones were found to be scattered in G3 (TI5 and TW4), G4 (TW6) and G6 (TW5), dominated by the genera Porites, Acropora and Isopora, respectively. Within G1, the genera 
Table 2. Diversity and distribution patterns of coral genera at 20 reef sites in TIMP.

\begin{tabular}{|c|c|c|c|c|c|c|c|c|c|c|c|c|c|c|c|c|c|c|c|c|c|c|}
\hline \multirow[b]{2}{*}{ No. } & \multirow[b]{2}{*}{ Corals } & \multicolumn{6}{|c|}{ East coast zone } & \multicolumn{6}{|c|}{ West coast zone } & \multicolumn{8}{|c|}{ Isolated zone } & \multirow{2}{*}{$\begin{array}{c}\text { Mean } \\
(\mathbf{\%})\end{array}$} \\
\hline & & $\begin{array}{c}\mathrm{TE} \\
1\end{array}$ & $\begin{array}{c}\text { TE } \\
2\end{array}$ & \begin{tabular}{|c} 
TE \\
3
\end{tabular} & \begin{tabular}{|c|}
$\mathrm{TE}$ \\
4
\end{tabular} & $\begin{array}{c}\mathrm{TE} \\
5\end{array}$ & $\begin{array}{c}\mathrm{TE} \\
6\end{array}$ & $\begin{array}{c}\mathrm{TW} \\
1\end{array}$ & $\begin{array}{c}\text { TW } \\
2\end{array}$ & $\begin{array}{c}\mathrm{TW} \\
3\end{array}$ & $\begin{array}{c}\mathrm{TW} \\
4\end{array}$ & $\begin{array}{c}\text { TW } \\
5\end{array}$ & $\begin{array}{c}\text { TW } \\
6\end{array}$ & $\begin{array}{c}\text { TI } \\
1\end{array}$ & \begin{tabular}{|c|} 
TI \\
2
\end{tabular} & $\begin{array}{c}\text { TI } \\
3\end{array}$ & $\begin{array}{c}\text { TI } \\
4\end{array}$ & $\begin{array}{c}\text { TI } \\
5\end{array}$ & $\begin{array}{c}\text { TI } \\
6\end{array}$ & \begin{tabular}{|c|} 
TI \\
7
\end{tabular} & $\begin{array}{c}\text { TI } \\
8\end{array}$ & \\
\hline & \multicolumn{22}{|c|}{ SCLERACTINIAN HARD CORALS } \\
\hline & \multicolumn{21}{|l|}{ Acroporidae } & 5.03 \\
\hline 1 & Acropora & $\begin{array}{c}++ \\
+++\end{array}$ & $\begin{array}{l}++ \\
++\end{array}$ & $\begin{array}{c}++ \\
+++\end{array}$ & $\begin{array}{l}++ \\
++\end{array}$ & \begin{tabular}{l|}
++ \\
++
\end{tabular} & $\begin{array}{l}++ \\
++\end{array}$ & $\begin{array}{l}++ \\
++\end{array}$ & $\begin{array}{c}+++ \\
+++\end{array}$ & $\begin{array}{c}++ \\
+++\end{array}$ & +++ & $\begin{array}{c}+++ \\
+++\end{array}$ & \begin{tabular}{|c|}
+++ \\
+++
\end{tabular} & \begin{tabular}{|l|}
++ \\
++
\end{tabular} & $\begin{array}{l}++ \\
++\end{array}$ & $\begin{array}{l}++ \\
++\end{array}$ & $\begin{array}{c}++ \\
+++\end{array}$ & +++ & $\begin{array}{l}++ \\
++\end{array}$ & \begin{tabular}{|c|}
++ \\
+++ \\
+
\end{tabular} & $\begin{array}{c}+++ \\
+++\end{array}$ & 1.02 \\
\hline 2 & Alveopora & + & - & - & - & + & - & - & - & - & - & - & - & - & - & - & - & - & - & - & - & 0.05 \\
\hline 3 & Anacropora & - & - & - & - & + & - & + & - & - & - & - & - & + & ++ & - & - & - & - & - & - & .15 \\
\hline 4 & Astreo, & + & + & + & ++ & + & + & ++ & + & + & + & - & - & - & ++ & + & + & - & - & - & - & .45 \\
\hline 5 & Isopora & - & - & - & + & + & + & + & + & +++ & $\begin{array}{l}++ \\
++\end{array}$ & $\begin{array}{c}++ \\
+++\end{array}$ & +++ & - & + & ++ & - & - & - & - & - & $t .03$ \\
\hline \multirow[t]{2}{*}{6} & Montipora & +++ & +++ & +++ & ++ & +++ & $\begin{array}{l}++ \\
++\end{array}$ & ++ & $\begin{array}{l}++ \\
++\end{array}$ & ++ & ++ & ++ & +++ & +++ & +++ & ++ & ++ & ++ & $\begin{array}{l}++ \\
++\end{array}$ & $\begin{array}{c}++ \\
+++ \\
+\end{array}$ & $\begin{array}{l}++ \\
++\end{array}$ & .33 \\
\hline & \multicolumn{21}{|l|}{ Agariciidae } & 2.58 \\
\hline 1 & Coeloseris & - & - & - & - & + & + & - & - & - & - & - & - & + & - & - & - & - & - & - & - & 0.02 \\
\hline 8 & Gardinerose & + & - & - & - & + & + & - & - & + & - & - & - & + & + & + & - & + & - & - & - & .05 \\
\hline 9 & Leptc & - & - & - & - & + & - & - & - & - & - & - & - & - & - & - & - & + & - & - & - & .02 \\
\hline 10 & Pavona & + & + & ++ & ++ & + & ++ & + & ++ & ++ & ++ & + & - & + & + & ++ & $\begin{array}{l}++ \\
++\end{array}$ & ++ & +++ & + & + & 2.49 \\
\hline & Astroc & & & & & & & & & & & & & & & & & & & & & .04 \\
\hline 11 & Stylocoeniella & - & - & - & + & + & - & - & - & - & - & - & - & - & - & - & - & - & - & - & - & 0.04 \\
\hline & Coscir & & & & & & & & & & & & & & & & & & & & & 0.06 \\
\hline 12 & Cosci & - & + & - & - & - & - & - & + & - & - & + & - & - & - & - & - & + & - & - & - & .06 \\
\hline & Dendr & & & & & & & & & & & & & & & & & & & & & 0.20 \\
\hline 13 & Turbinaria & - & + & - & + & + & + & + & + & + & - & - & - & - & + & + & + & ++ & & - & - & 0.20 \\
\hline & Diplo & & & & & & & & & & & & & & & & & & & & & 0.75 \\
\hline 14 & Diploastrea & + & + & + & ++ & ++ & ++ & + & + & - & + & - & - & ++ & + & - & - & + & - & - & + & 0.75 \\
\hline & Euphylliidae & & & & & & & & & & & & & & & & & & & & & 5.40 \\
\hline 15 & Euph & + & + & + & + & + & ++ & + & - & + & + & 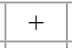 & - & + & - & + & + & + & - & ++ & ++ & .77 \\
\hline 16 & Galaxea & +++ & ++ & +++ & +++ & +++ & +++ & ++ & ++ & ++ & ++ & + & + & +++ & ++ & ++ & + & ++ & ++ & \begin{tabular}{|l|}
++ \\
++
\end{tabular} & + & 3.74 \\
\hline 17 & Pachyseris & ++ & + & + & ++ & ++ & ++ & + & + & + & + & + & + & + & ++ & + & + & ++ & + & - & + & 0.89 \\
\hline & Fungiidae & & & & & & & & & & & & & & & & & & & & & 4.27 \\
\hline 18 & Ctenactis & - & + & - & - & + & + & + & - & + & + & + & - & + & + & + & ++ & - & - & - & + & .24 \\
\hline 19 & Cycloseris & - & - & - & - & + & - & + & - & - & - & - & - & - & - & + & + & - & - & - & - & 08 \\
\hline 20 & Danafung & - & - & - & - & - & - & - & - & - & - & - & - & - & - & + & - & - & - & - & + & .06 \\
\hline 21 & Fungia & + & + & + & + & ++ & ++ & + & ++ & ++ & +++ & ++ & ++ & + & + & $\begin{array}{l}++ \\
++\end{array}$ & ++ & - & ++ & ++ & ++ & 1.90 \\
\hline 22 & Heliofi & - & - & - & - & - & - & - & - & - & - & - & - & - & - & - & - & - & + & + & + & .07 \\
\hline 23 & Herpolitha & - & - & + & - & - & - & - & + & + & - & + & - & - & + & + & + & + & - & - & - & .08 \\
\hline 24 & Lithophyllon & + & + & + & - & + & + & + & + & ++ & ++ & ++ & - & + & ++ & ++ & ++ & - & + & + & + & .81 \\
\hline 25 & Lobact & - & - & + & - & - & - & - & - & + & - & - & - & - & - & - & - & - & - & - & - & 01 \\
\hline 26 & Pleuractis & + & - & - & - & + & + & + & - & ++ & - & + & - & + & + & ++ & ++ & - & - & ++ & ++ & .64 \\
\hline 27 & Podabacia & + & - & - & - & - & - & - & + & - & - & - & - & - & - & - & - & - & - & - & - & .01 \\
\hline 28 & Polyphyllia & + & - & + & - & + & + & + & + & + & - & + & - & + & + & + & + & + & - & - & - & 10 \\
\hline 29 & Sandalolitha & + & + & + & + & + & + & + & - & + & - & + & + & - & + & ++ & + & + & - & - & - & 28 \\
\hline & Lobophylliidae & & & & & & & & & & & & & & & & & & & & & .52 \\
\hline 30 & Acanthastrea & ++ & ++ & ++ & + & + & + & + & - & + & + & - & + & + & + & + & - & + & + & - & - & .47 \\
\hline 31 & Echinophyllia & + & + & + & + & + & + & + & - & - & - & + & + & + & + & - & - & - & - & - & + & .11 \\
\hline 32 & Homophyllia* & - & - & - & - & - & - & - & - & - & - & - & - & - & - & - & - & + & - & - & - & .01 \\
\hline 33 & Lobophyllia & +++ & +++ & ++ & +++ & ++ & +++ & ++ & ++ & + & ++ & ++ & ++ & +++ & ++ & ++ & ++ & ++ & + & + & ++ & 3.04 \\
\hline 34 & Micromussa & + & + & + & - & + & - & - & - & - & - & - & - & - & - & - & - & - & - & - & - & 0.01 \\
\hline 35 & Oxypora* & - & - & - & - & + & - & - & - & - & - & - & - & - & - & - & - & - & - & - & - & 0.00 \\
\hline & Merulinidae & & & & & & & & & & & & & & & & & & & & & 20.86 \\
\hline 36 & Astrea & + & + & + & - & + & - & + & + & - & + & - & - & + & + & + & - & ++ & - & + & + & 0.35 \\
\hline 37 & Coelastrea & ++ & ++ & ++ & + & ++ & ++ & + & + & + & + & - & ++ & ++ & ++ & ++ & - & ++ & - & - & - & 0.86 \\
\hline 38 & Cyphastrea & ++ & ++ & ++ & ++ & ++ & ++ & + & ++ & - & + & - & - & ++ & ++ & ++ & + & ++ & - & - & ++ & 1.26 \\
\hline 39 & Dipsastraea & +++ & +++ & ++ & ++ & +++ & +++ & ++ & ++ & + & ++ & ++ & ++ & +++ & +++ & ++ & + & ++ & + & + & + & 3.30 \\
\hline 40 & Echinopo & + & + & + & - & + & ++ & + & - & +++ & + & - & - & + & + & + & + & + & +++ & - & - & 0.75 \\
\hline 41 & Favites & +++ & +++ & +++ & ++ & +++ & ++ & ++ & ++ & + & ++ & + & + & +++ & +++ & ++ & ++ & ++ & + & - & ++ & 3.01 \\
\hline 42 & Goniastrea & +++ & +++ & $\begin{array}{l}++ \\
++\end{array}$ & +++ & ++ & ++ & $\begin{array}{l}+++ \\
++\end{array}$ & ++ & ++ & +++ & +++ & ++ & +++ & $\begin{array}{l}++ \\
++\end{array}$ & ++ & ++ & ++ & ++ & + & + & 5.35 \\
\hline
\end{tabular}




\begin{tabular}{|c|c|c|c|c|c|c|c|c|c|c|c|c|c|c|c|c|c|c|c|c|c|c|}
\hline \multirow[b]{2}{*}{ No. } & \multirow[b]{2}{*}{ Corals } & \multicolumn{6}{|c|}{ East coast zone } & \multicolumn{6}{|c|}{ West coast zone } & \multicolumn{8}{|c|}{ Isolated zone } & \multirow{2}{*}{$\begin{array}{c}\text { Mean } \\
(\mathbf{\%})\end{array}$} \\
\hline & & $\begin{array}{c}\text { TE } \\
1\end{array}$ & $\begin{array}{c}\text { TE } \\
2\end{array}$ & $\begin{array}{l}\text { TE } \\
3\end{array}$ & \begin{tabular}{|c|}
$\mathrm{TE}$ \\
4
\end{tabular} & $\begin{array}{c}\mathrm{TE} \\
5\end{array}$ & $\begin{array}{c}\text { TE } \\
6\end{array}$ & $\begin{array}{c}\text { TW } \\
1\end{array}$ & $\begin{array}{c}\text { TW } \\
2\end{array}$ & $\begin{array}{c}\text { TW } \\
3\end{array}$ & $\begin{array}{c}\text { TW } \\
4\end{array}$ & $\begin{array}{c}\text { TW } \\
5\end{array}$ & $\begin{array}{c}\text { TW } \\
6\end{array}$ & $\begin{array}{c}\text { TI } \\
1\end{array}$ & $\begin{array}{l}\text { TI } \\
2\end{array}$ & $\begin{array}{c}\text { TI } \\
3\end{array}$ & \begin{tabular}{|c|}
$\mathrm{TI}$ \\
4
\end{tabular} & $\begin{array}{c}\text { TI } \\
5\end{array}$ & \begin{tabular}{|c|} 
TI \\
6
\end{tabular} & $\begin{array}{c}\text { TI } \\
7\end{array}$ & $\begin{array}{c}\text { TI } \\
8\end{array}$ & \\
\hline 43 & Hydnophora & + & + & + & ++ & + & ++ & + & + & + & + & + & - & ++ & + & + & - & + & + & + & ++ & .65 \\
\hline 44 & Leptoria & + & + & + & + & + & + & + & + & - & - & - & - & + & - & - & - & - & + & - & - & .10 \\
\hline 45 & Merulina & + & + & + & + & + & + & + & + & + & - & + & - & ++ & + & - & + & - & + & - & - & 0.31 \\
\hline 46 & Oulophyllia & + & + & + & - & + & + & - & + & - & - & - & - & - & - & - & - & + & + & - & ++ & 19 \\
\hline 47 & Paragol & + & ++ & + & - & + & + & - & - & - & - & - & - & + & + & - & - & - & - & - & - & .15 \\
\hline 48 & Pectinia & - & + & - & - & - & - & - & - & - & - & - & - & - & + & - & - & - & - & - & - & .01 \\
\hline 49 & Platygyra & +++ & +++ & +++ & +++ & +++ & $\begin{array}{l}++ \\
++\end{array}$ & ++ & ++ & ++ & ++ & + & ++ & +++ & +++ & ++ & +++ & $\begin{array}{c}++ \\
++\end{array}$ & ++ & + & ++ & 4.56 \\
\hline 50 & Scapophyllia* & + & - & - & - & - & - & - & - & - & - & - & - & - & - & - & - & - & - & - & - & 0.01 \\
\hline \multirow[t]{2}{*}{51} & Trachyphyllia* & - & - & - & - & - & + & - & - & - & - & - & - & - & - & - & - & - & - & - & - & 0.00 \\
\hline & \multicolumn{21}{|l|}{ Pocilloporidae } & 77 \\
\hline 52 & Pocillopora & ++ & ++ & ++ & ++ & ++ & ++ & ++ & ++ & ++ & + & ++ & $\begin{array}{c}++ \\
+++\end{array}$ & ++ & ++ & +++ & ++ & ++ & +++ & ++ & +++ & 4.68 \\
\hline \multirow[t]{2}{*}{53} & Stylophora & - & - & - & - & - & - & - & - & + & - & + & - & - & - & + & + & - & - & - & - & 0.09 \\
\hline & \multicolumn{21}{|l|}{ Poritidae } & 12.73 \\
\hline 54 & Goniopora & - & + & + & - & + & + & - & - & + & - & + & - & + & + & + & - & - & - & ++ & ++ & 0.39 \\
\hline 55 & Porites & +++ & ++ & ++ & $\begin{array}{l}++ \\
++ \\
+\end{array}$ & +++ & +++ & $\begin{array}{l}++ \\
++\end{array}$ & $\begin{array}{l}++ \\
++\end{array}$ & $\begin{array}{c}++ \\
+++ \\
++\end{array}$ & $\begin{array}{c}++ \\
+++\end{array} \mid$ & +++ & + & $\begin{array}{l}++ \\
++\end{array}$ & $\begin{array}{l}++ \\
++\end{array}$ & +++ & $\begin{array}{l}++ \\
++\end{array}$ & $\begin{array}{c}++ \\
+++\end{array}$ & +++ & ++ & ++ & 12.34 \\
\hline & Psamm & & & & & & & & & & & & & & & & & & & & & 0.77 \\
\hline 56 & Psammo & + & - & + & + & + & + & ++ & + & + & + & - & - & ++ & + & + & ++ & + & + & - & ++ & 0.74 \\
\hline & Sider & & & & & & & & & & & & & & & & & & & & & 0.00 \\
\hline 57 & Pseudo & - & - & + & - & - & - & - & - & - & - & - & - & - & - & - & - & - & - & - & - & 0.00 \\
\hline & Incert & & & & & & & & & & & & & & & & & & & & & .74 \\
\hline 58 & Lept & + & + & + & - & + & - & + & + & + & + & + & - & + & + & + & ++ & ++ & - & - & + & 51 \\
\hline 59 & $P$ & - & - & - & - & - & - & - & - & + & - & - & - & - & - & + & - & - & + & - & - & 03 \\
\hline 60 & Plero & - & - & - & + & + & + & + & + & + & - & - & + & + & - & + & + & + & + & + & + & .16 \\
\hline 61 & Plesia & - & - & + & - & + & - & + & - & - & - & - & - & - & - & - & - & + & + & - & + & 04 \\
\hline & NON & $\mathrm{ANH}$ & HARD & $\mathrm{CO}$ & ALS & & & & & & & & & & & & & & & & & \\
\hline & Helio & & & & & & & & & & & & & & & & & & & & & 0.81 \\
\hline 62 & Heliopora & + & - & + & - & ++ & + & +++ & + & + & + & + & - & + & + & + & ++ & - & - & - & - & 0.81 \\
\hline & Mill & & & & & & & & & & & & & & & & & & & & & 0.68 \\
\hline 63 & Millepora & + & + & ++ & ++ & - & + & - & + & + & - & - & + & - & + & + & - & + & ++ & - & - & 0.68 \\
\hline & Distichopor & & & & & & & & & & & & & & & & & & & & & 0.02 \\
\hline 64 & Distic & - & - & - & - & - & - & - & - & - & - & - & - & - & - & + & - & - & - & - & - & 02 \\
\hline & SOF & & & & & & & & & & & & & & & & & & & & & \\
\hline & Alcy & & & & & & & & & & & & & & & & & & & & & 5.66 \\
\hline 65 & Sinulc & + & +++ & ++ & +++ & +++ & ++ & +++ & + & + & ++ & 1 & + & +++ & ++ & + & - & ++ & ++ & + & - & 00 \\
\hline 66 & $S$ & ++ & ++ & + & + & + & ++ & ++ & + & - & + & 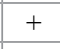 & - & + & - & +++ & + & + & - & + & - & 86 \\
\hline 67 & Lobop & ++ & +++ & ++ & ++ & ++ & ++ & ++ & + & + & + & + & - & +++ & + & + & + & - & + & - & - & .74 \\
\hline 68 & 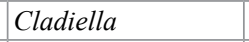 & + & - & + & - & + & - & - & - & - & + & - & - & + & - & + & - & - & - & - & - & .05 \\
\hline 69 & sum & - & - & - & - & - & - & - & - & - & - & - & - & + & - & - & + & - & - & - & - & 02 \\
\hline & Nephtheidae & & & & & & & & & & & & & & & & & & & & & 0.66 \\
\hline 70 & Nepthea & - & - & + & - & + & - & - & + & - & - & - & + & - & - & $\begin{array}{l}++ \\
++\end{array}$ & + & ++ & - & - & - & .64 \\
\hline 71 & Scleronephth & - & - & - & - & + & + & - & - & - & - & - & - & - & - & - & - & - & - & - & - & .01 \\
\hline & Ellisellidae & & & & & & & & & & & & & & & & & & & & & 0.35 \\
\hline 72 & Junce & . & - & - & - & ++ & + & ++ & - & - & - & - & - & - & - & - & - & + & - & - & + & 0.28 \\
\hline 73 & Dichotella & - & - & - & - & - & - & + & - & - & - & - & - & - & - & - & - & + & - & - & - & 0.07 \\
\hline & Clavulariida & & & & & & & & & & & & & & & & & & & & & 0.01 \\
\hline 74 & Clavularia & - & - & + & - & + & - & - & - & - & - & - & - & - & - & - & - & + & - & - & - & 0.01 \\
\hline & Xeniidae & & & & & & & & & & & & & & & & & & & & & 0.00 \\
\hline 75 & Xenia* & 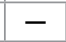 & - & - & - & - & + & - & - & - & - & - & - & - & - & - & - & - & - & - & - & 0.00 \\
\hline & Briareidae & & & & & & & & & & & & & & & & & & & & & 0.11 \\
\hline 76 & Briareum & + & - & - & - & - & - & - & - & - & + & - & - & - & - & - & - & - & + & + & + & 0.11 \\
\hline & Acanthoge & & & & & & & & & & & & & & & & & & & & & 0.01 \\
\hline 77 & Acantho & - & - & - & - & - & - & - & - & - & - & - & - & - & - & - & - & + & - & - & - & 0.01 \\
\hline & Total Genera & 46 & 40 & 46 & 33 & 57 & 47 & 44 & 38 & 40 & 33 & 32 & 21 & 42 & 42 & 46 & 35 & 41 & 30 & 22 & 33 & \\
\hline
\end{tabular}

Note: + : one or few covering $<1 \%$ of coral colonies; ++ : uncommon covering $1-5 \%$ of coral colonies; +++ : common covering $6-10 \%$ of coral colonies; ++++: abundant covering $11-20 \%$ of coral colonies; and +++++: dominant covering $>20 \%$ of coral colonies. Suffix $*$ indicates a rare coral genus. 

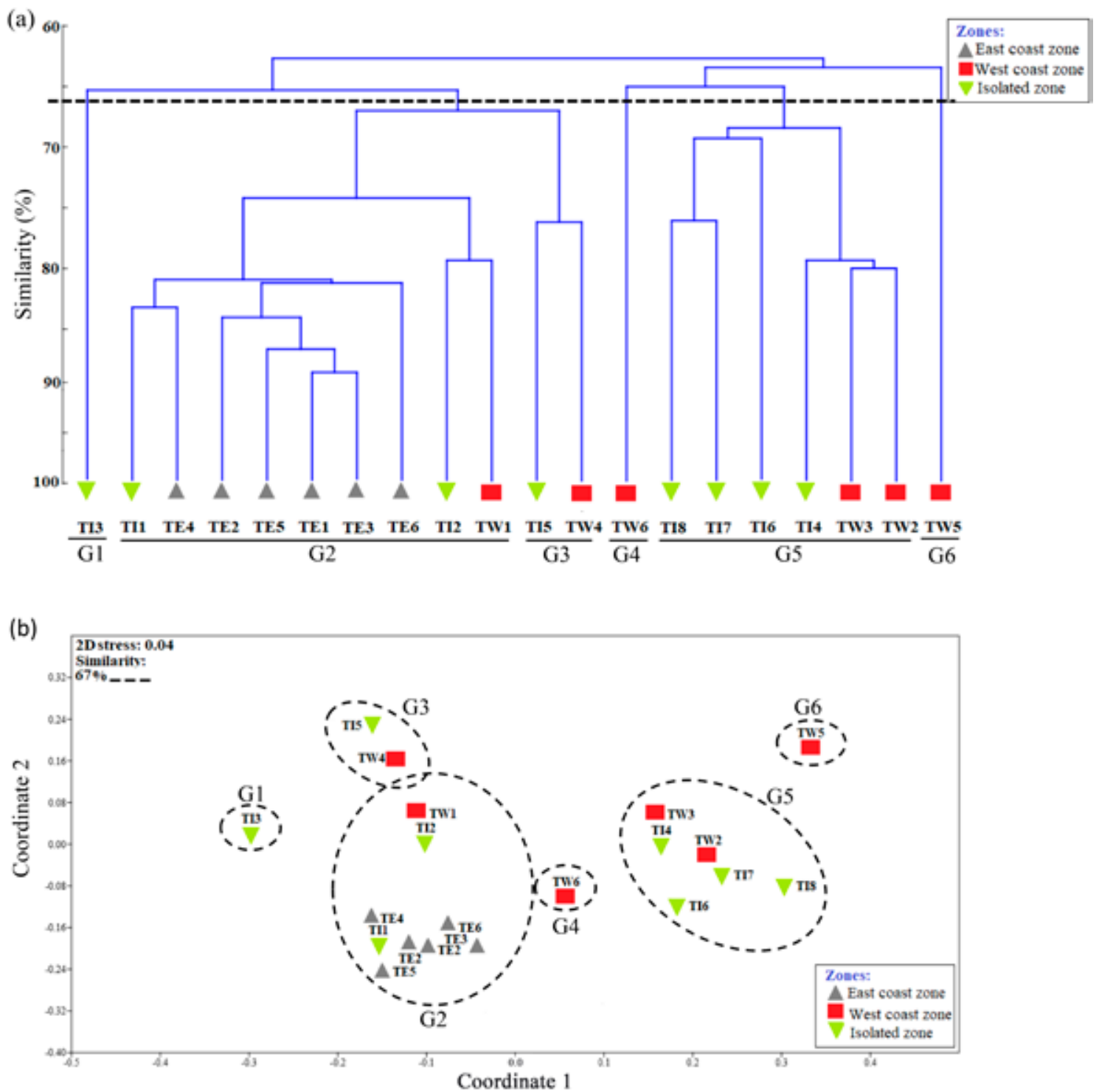

Figure 2. Dendrogram (a) and nMDS plot (b) clustered all reef sites within six groups (G1-G6) based on a $67 \%$ similarity threshold. All groups were separated based on the mean percentage cover of coral genera.

Acropora, Fungia, Nepthea, Pocillopora and Porites were dominant at TI3 located in the isolated zone of Tioman Island.

\section{DISCUSSION}

\section{Coral condition in Tioman Island Marine Park}

Coral reefs in TIMP may have been subjected to extensive coastal development and widespread tourist activities, with an increased number of tourists over the years (Shahbudin et al. 2017; Akmal et al. 2019). Earlier coral surveys indicated that reef sites in TIMP were in 'fair' to 'good' coral condition (Harborne et al. 2000; Toda et al. 2007; Shahbudin et al. 2017). Following the current surveys at 20 fringing reef sites, no remarkable change of the live coral cover was recorded. All reef sites were varied between 'fair' to 'good' coral condition but some of them had a relatively low live coral cover and closely approached the borderline of 'poor' coral condition $(<25 \%)$.

Among 20 surveyed reef sites, Juara Bay (TE4) and Bakau Bay (TI3) showed a lower live coral cover. A high dead coral cover, mainly from coral rubble, recorded at these reef sites indicated direct and indirect pressures from anthropogenic activities. A previous report had also a relatively low hard coral cover at TE4 and high dead coral cover at the survey site located nearby to TI3 (Harborne et al. 2000). These reef sites were impacted with high sedimentation and siltation loads (Harborne et al. 2000; Lee and Mohamed 2011). Throughout the surveys, many coral colonies and abiotic substrates, such as rocks and boulders, were also found to be covered with a layer of silt. Hence, the sedimentation problem together with deleterious effects of nutrient enrichment, which may be from 

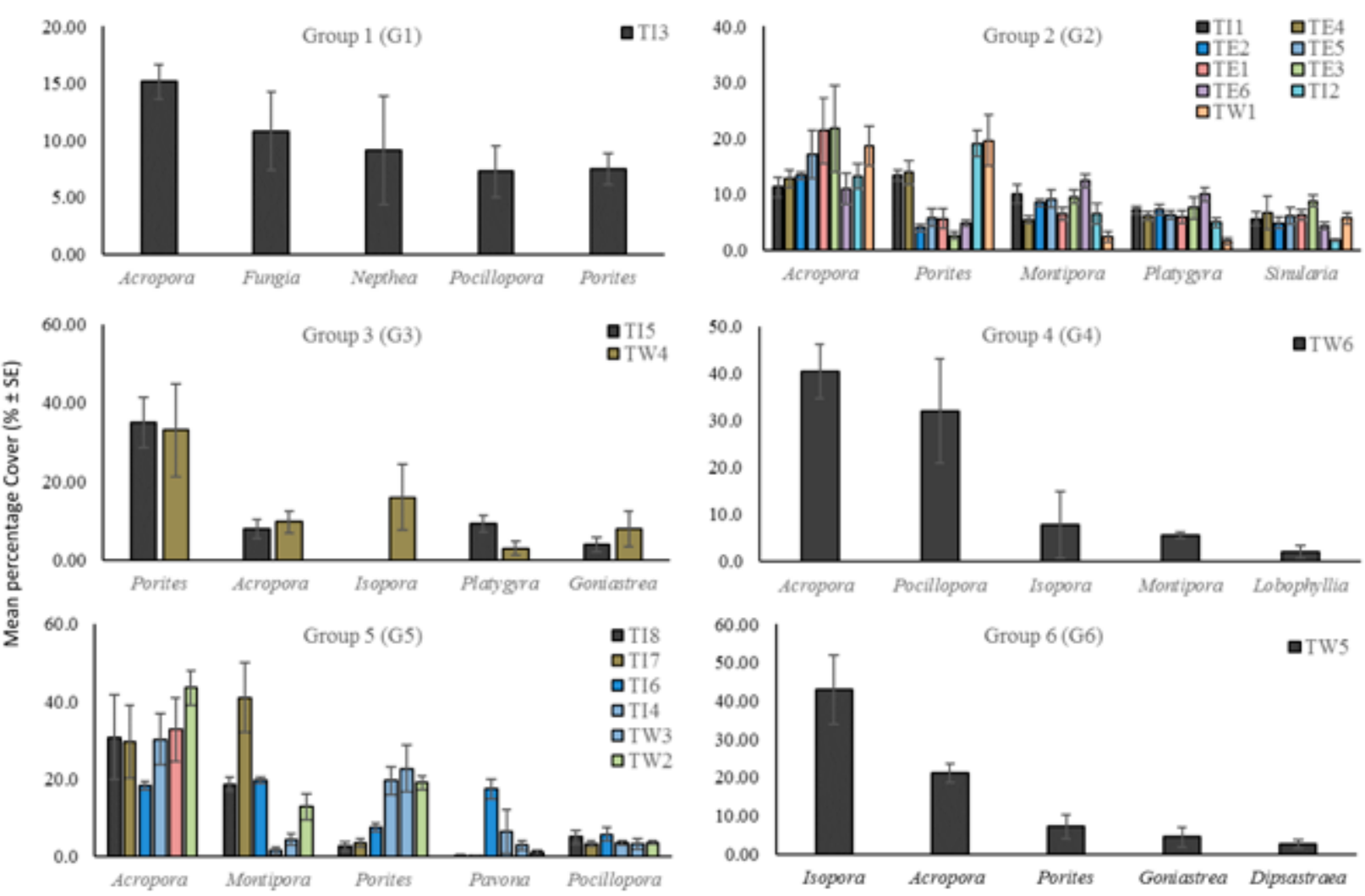

Figure 3. Six groups derived from cluster and nMDS plot. Each group consists of five different dominant coral genera derived from the SIMPER analysis and values are indicated based on their mean percentage cover $(\% \pm \mathrm{SE})$.

nearby resorts at TE4, might contribute to future 'poor' coral condition.

Of the three categorized reef zones around the island, the east coast exhibited the highest average live coral cover and was categorized as being in 'good' coral condition. The 'good' coral condition established in this zone may be due to minimal human impacts, with no local human settlements and less coastal development activities. Additionally, coral reefs in the east coast zone have less divers and snorkelers as they are directly facing the South China Sea and frequently exposed to strong currents and waves (Shahbudin et al. 2017). This is further supported by the minimal physical damage observed on coral colonies and breakage of coral fragments due to the trampling action along the survey transects. In fact, strong currents and waves especially during the northeast monsoon season may also have contributed to a higher soft coral cover recorded at TE1, TE2 and TE3. Soft corals are able to thrive on this exposed reef sites since they have a flexible structure that can tolerate the high current, wave and sediment actions (Fabricius and Alderslade 2001).

A high average live coral cover was also recorded in the isolated zone, with three reef sites (TI1, TI4, TI6) categorized as being in 'good' coral condition. However, most reef sites in the isolated zone were in 'fair' coral condition, and TI7, located in the south-west of Tioman Island, showed the highest mean percentage of dead corals with more than $50 \%$ covered by coral rubble fragments with filamentous algae. Some extensive coral rubble areas were also observed at TI7, suggesting reef destruction caused by boating activities in this area. Additionally, all reef sites located in the north-west of Tioman Island (TI1-TI6) are often visited by snorkelers and divers. For example, more than 10 snorkeling and diving boats were regularly observed during fieldworks. Some evidence of multiple breakages of coral fragments were seen at many reef sites in this isolated zone, suggested from direct fin contact by inexperienced divers. There were also signs of multifocal and diffused patterns of bleaching observed on the surface of coral colonies (obviously found on the surface of Porites spp.) at Labas Island (TI5) that may be linked to the significant impacts of the bleaching events.

The west coast zone showed the lowest average live coral cover, and all reef sites, except TW2, were categorized as being in 'fair' coral condition. The extensive coastal development is potentially the main influence on the coral condition at most reef sites surveyed. Many human settlements and resorts can be found along the coastal areas in the west coast of Tioman. By 2008, over 47 resorts have been developed across the Air Batang (20 resorts), Tekek (14 resorts) and Salang (13 resorts) villages (Omar et al. 2015). To date, a total of 72 resorts including small, medium and world standard classes (e.g. Berjaya, Japamala, Tunamaya and Melina Beach 
Resorts) have been developed in Tioman and are mostly concentrated in the west coast area (RCM 2018). Rapid growth and any unsustainable coastal development activities may threaten the health of coral reefs (Jordan et al. 2010; Akmal and Shahbudin 2020).

All reef sites in the west coast zone were observed to be a focal point for water-based recreational activities, such as snorkeling, diving and boating. The reefs along the west coast zone are considered the most favourable sites for snorkeling activity due to the shallow water fringing reef $(<2 \mathrm{~m}$ depth) area. As a result, the signs of abraded coral fragments, due to the trampling action by less experienced snorkelers and divers, were frequently observed at many reef sites within this zone. Inexperienced snorkelers and divers are frequently trampling, standing on and walking across the reef flat, and these have led to coral partial mortality due to the loosening and abrasion of coral fragments (Wielgus et al. 2004; Barker and Roberts 2004; Hannak et al. 2011; Webler and Jakubowski 2016; Giglio et al. 2020). These factors together with boating activity in shallow water areas might increase the re-suspension of bottom sediments. High suspended sediments covered on the surface of coral colonies cause coral mortality due to insufficient penetration of sunlight required for corals to undertake the photosynthesis process (Erftemeijer et al. 2012).

\section{Coral community structure in Tioman Island Marine Park}

Current survey efforts showed an increase in the total number of scleractinian coral species as compared with a previous study done by Akmal et al. (2019). When combined with the previous species lists published by Harborne et al. (2000), Affendi et al. (2005) and Affendi et al. (2007), the current checklist revealed a total of 355 species from 67 genera and 15 families (including 8 species from 5 genera of Incertae sedis) of the scleractinian coral in TIMP. This study also revealed 30 new scleractinian species records for TIMP, and 15 species for the east coast of Peninsular Malaysia, which supplements and updates the work done by Affendi and Rosman (2012). The current species list also identified 29 rare, 86 vulnerable and 3 endangered species in TIMP. When combined with the total number for non-scleractinian hard and soft corals, there was also a slight increase in genera diversity, as compared to a previous study conducted by Shahbudin et al. (2017). Unfortunately, a comparison of the soft coral diversity with other previous studies in Tioman Island could not be made due to a lack of available data. Hence, these updated coral species and genera lists, including all categorized threatened species, offer a baseline data and information to management personnel from the relevant authorities on the status of coral diversity in TIMP.
There was spatial variability in coral diversity among east coast, west coast and isolated zones. The east coast had a higher diversity of coral species and genera compared to other reef zones. The difference in coral diversity between reef zones could be related to variations in environmental conditions, such as habitat heterogeneity and wave exposure (Veron et al. 2009; Polónia et al. 2015). Field observations indicated that the reefs around the east coast consist of more structural habitats (crevices, spurs, grooves and overhangs) across the gentle reef slopes compared to the west coast and isolated (mainly dominated by rocky and sandy substratum) zones. Additionally, the reefs exposed to wind and currents in the east coast zone may limit a dense coverage of fast-growing Acropora and Montipora corals. Fast-growing corals are less resistant to breakage by relatively high wave energy (Madin and Connolly 2006; Denis et al. 2017). Hence, these environmental conditions may reflect the prevalence of various coral species within the reefs along the east coast zone, particularly from wave-resistant taxa, including Galaxea, Lobophyllia, Dipsastraea, Favites, Goniastrea, Platygyra and soft coral Sinularia.

The findings based on the distribution pattern of coral genera in Tioman Island showed that the genera Acropora, Montipora and Porites were classified as common to dominant at most reef sites surveyed. Genera Acropora (163 species) and Montipora ( 73 species), which encompassed more than $90 \%$ from the total number of Acroporidae family (259 species), are recognized to be naturally found distributed in the Indo-Pacific reefs (Veron 2000). These genera with various growth forms are also known as fast-growing corals with lateral growth rates of 5-20 cm per year (Done et al. 1991; Done 1999). They are rapidly outgrown and become more dominant under optimal conditions (considerable wave, current and sediment actions), compared to slow-growing coral, like massive Porites, with radial growth rates of $1-2 \mathrm{~cm}$ per year (Done et al. 1991; Done 1999). However, massive Porites colonies can withstand in harsh environmental conditions, such as high energy forces from wave and current actions due to their greater skeleton density compared to more fragile branching Acropora and foliose Montipora colonies (Madin and Connolly 2006; Halid et al. 2016). Moreover, Porites colonies have a higher tolerance towards fluctuation of suspended sediment concentrations compared to Acropora and Montipora colonies (Hong and Sasekumar 1981; Jones et al. 2015; Denis et al. 2017). Hence, it is suggested that the dominance of Acropora, Montipora and Porites within Tioman reefs could be linked with their ability to cope with any environmental conditions, such as currents, wave actions and sedimentation loads.

Coral genera, such as Isopora and Pocillopora, were dominant at some reef sites in the west coast zone. 
Meanwhile, genera Pavona, Galaxea, Fungia, Goniastrea, Platygyra and soft coral Nepthea were classified as abundant at some reef sites in the isolated zone. It can be observed that the branching Isopora and Pocillopora corals were found to dominate the sheltered area across the upper reef slope in the west coast zone. Meanwhile, massive Pavona, Galaxea, Goniastrea and Platygyra corals were found to dominate the fore reef area in the isolated zone, which is frequently exposed to strong wind during the northeast monsoon season. The difference in environmental gradients, such as wind and wave exposure, are probably the main factor influencing the variation in coral genera dominance across the reef zones (Cleary et al. 2006; Hoeksema 2012; Halid et al. 2016; Kamarumtham et al. 2016). Other factors, such as morphological structures and adaptive capacities, also play important roles in increasing coral survival and growth (Muko et al. 2000; Zawada et al. 2019). For example, massive and submassive corals (Pavona, Galaxea, Goniastrea, Platygyra) can tolerate current and wave actions through their hemispherical shape (Madin and Connolly 2006). They are also able to remove the accumulated sediment on surface through their own cleaning mechanisms such as mucus secretion and ciliary action (Hong and Sasekumar 1981). The tentacular action by free-living Fungia and massive Galaxea also enable them to repel suspended sediments and thrive in a high sediment load area (Erftemeijer et al. 2012; Junjie et al. 2014). Soft corals such as Sinularia and Nepthea are able to resist wave and currents due to their flexible skeleton structure (Fabricius and Alderslade 2001). Hence, all of these contribute as defensive mechanisms in coral survivorship at Tioman Island.

\section{CONCLUSION}

This study updated the current 'fair' condition, high diversity, and good complexity of live corals within reef sites in TIMP. Genera Acropora, Montipora and Porites were dominant across the reef sites in the study area. Most reef sites in the east coast zone have 'good' coral condition and consist of high coral diversity, potentially due to the low rates of human activities. The intensive tourism activities along with the cumulative impacts on adjacent coastal development might contribute to 'fair' coral condition and lower coral diversity at most reef sites in the west coast and isolated zones.

\section{ACKNOWLEDGEMENTS}

This research was fully funded from E-Science Grant (SF16-002-0071) under the Ministry of Energy, Science, Technology, Environment \& Climate Change
(MESTECC). The authors wish to express their gratitude to all laboratory teams from Kulliyyah of Science (KOS) and Institute of Oceanography and Maritime Studies (INOCEM), International Islamic University Malaysia (IIUM) for logistic, equipment and technical assistances. Appreciation also goes to the section of Marine Park Malaysia for providing a permit (No. JTLM 630-7 Jld. $8-49)$ to conduct scientific research in the protected marine area of Tioman Island.

\section{REFERENCES}

Affendi, Y. A., and F. R. Rosman. 2012. Current knowledge on sclerectinian coral diversity of Peninsular Malaysia. In Malaysia's marine biodiversity: inventory and current status, edited by Kamarruddin, I., Mohamed, C. A. R., Rozaimi, M. J., Kee Alfian, A. A., Fitra, A. Z., and Lee J.N., 21-31. Department of Marine Park Malaysia, Putrajaya.

Affendi, Y. A., B. H. Tajuddin, Y. L. Lee, A. A. Kee Alfian, and Y. Yusri. 2005. Scleractinian coral diversity of Kg. Tekek, Pulau Tioman Marine Park. In Proceedings of $2^{\text {nd }}$ Regional Symposium on Environment and Natural Resources, Kuala Lumpur, 20-31.

Affendi, Y. A., B. H. Tajuddin, Y. Yusof, A. A. Kee Alfian, N. L. Wong, J. L. S. Ooi, and M. N. Nayan. 2007. The marine biological resources survey of the proposed area for Pulau Tioman airport Pahang Darul Makmur. Universiti Malaya Maritime Research Centre (UMMaritime) University Malaya, Kuala Lumpur. Technical report submitted to the Marine Park Department, Ministry of Natural Resources \& Environment, Putrajaya, Malaysia, $226 \mathrm{pp}$.

Akmal, K. F., and S. Shahbudin. 2020. Baseline assessment of coral health and disease in Tioman Island Marine Park, Malaysia. Community Ecology 21: 285-301.

Akmal, K. F., S. Shahbudin, M. H. M. Faiz, and Y. M. Hamizan. 2019. Diversity and abundance of scleractinian corals in the east coast of Peninsular Malaysia: a case study of Redang and Tioman Islands. Ocean Science Journal 54: 435-456.

Barker, N. H., and C. M. Roberts. 2004. Scuba diver behaviour and the management of diving impacts on coral reefs. Biological conservation 120: 481-489.

Bray, J. R., and J. T. Curtis. 1957. An ordination of the upland forest communities of southern Wisconsin. Ecological Monographs 27: 325-349.

Burke, L., K. Reytar, M. D. Spalding, and A. Perry. 2012. Reefs at Risk Revisited in the Coral Triangle. Washington, DC: World Resources Institute, $72 \mathrm{pp}$.

Chou, L. M., C. R. Wilkinson, W. R. Y. Licuanan, P. Alino, A. C. Cheshire, M. G. K. Loo, S. Tangjaitrong, S. Sudara, A. R. Ridzwan, and Soekarno. 1994. Status of coral reefs in the ASEAN region. In Proceedings Third 
ASEAN-Australia Symposium on Living Coastal Resources, Chulalongkorn University, Bangkok, 1-10.

Cleary, D. F., R. Suharsono, and B. W. Hoeksema. 2006. Coral diversity across a disturbance gradient in the Pulau Seribu reef complex off Jakarta, Indonesia. Biodiversity and Conservation 15: 3653-3674.

Denis, V., L. Ribas-Deulofeu, N. Sturaro, C. Y. Kuo, and C. A. Chen. 2017. A functional approach to the structural complexity of coral assemblages based on colony morphological features. Scientific Reports 7: 1-11.

Department of Marine Park Malaysia. 2011. Handbook of the Living Marine Resources of Malaysia Marine Park. Ministry of Natural Resources and Environment, Putrajaya, Malaysia, 23 pp.

Department of Marine Park Malaysia. 2019. Total number of visitors in marine parks from year 2000 to year 2019. Web service available online at: http://marinepark.dof.gov.

Done, T. J. 1999. Coral community adaptability to environmental change at the scales of regions, reefs and reef zones. American zoologist 39: 66-79.

Done, T. J., P. K. Dayton, A. E. Dayton, and R. Steger. 1991. Regional and local variability in recovery of shallow coral communities: Moorea, French Polynesia and central Great Barrier Reef. Coral Reefs 9: 183-192.

Erftemeijer, P. L., B. Riegl, B. W. Hoeksema, and P. A. Todd. 2012. Environmental impacts of dredging and other sediment disturbances on corals: a review. Marine Pollution Bulletin 64: 1737-1765.

Fabricius, K., and P. Alderslade. 2001. Soft corals and sea fans: a comprehensive guide to the tropical shallow water genera of the central-west Pacific, the Indian Ocean and the Red Sea. Australian Institute of Marine Science 5: 154-157.

Fabricius, K. E., and D. McCorry. 2006. Changes in octocoral communities and benthic cover along a water quality gradient in the reefs of Hong Kong. Marine Pollution Bulletin 52: 22-33.

Giglio, V. J., O. J. Luiz, and C. E. Ferreira. 2020. Ecological impacts and management strategies for recreational diving: A review. Journal of Environmental Management 256: 109949.

Halid, N. H., Z. Ahmad, K. Kamarumtham, S. Saad, M. F. Khodzori, M. F. M. Hanafiah, and M. H. Yusof. 2016. The effect of current on coral growth form in selected areas of Tioman Island, Pahang. Transactions on Science and Technology 3: 393-4002.

Hammer, Ø., D. A. Harper, and P. D. Ryan. 2001. PAST: Paleontological statistics software package for education and data analysis. Palaeontologia electronica 4 (1): 9.

Hanim, N., M. Salleh, and O. Redzuan. 2010. Importance satisfaction analysis for Tioman Island Marine Park. Munich Personal RePEc Archive (MPRA Paper): 22679.
Hannak, J. S., S. Kompatscher, M. Stachowitsch, and J. Herler. 2011. Snorkelling and trampling in shallow-water fringing reefs: Risk assessment and proposed management strategy. Journal of Environmental Management 92: 2723-2733.

Harborne, A., D. Fenner, A. Barnes, M. Beger, S. Harding, and T. Roxburgh. 2000. Status report on the coral reefs of the east coast of Peninsula Malaysia. London, UK: Coral Cay Conservation Ltd.

Hoeksema, B. W. 2012. Evolutionary trends in onshoreoffshore distribution patterns of mushroom coral species (Scleractinia: Fungiidae). Contributions to Zoology 81: 199-221.

Hong, G. A., and A. Sasekumar. 1981. The community structure of the Fringing Coral Reef, Cape Rachado Malaya. Atoll Research Bulletin 16 (244).

Jones, R., G. F. Ricardo, and A. P. Negri. 2015. Effects of sediments on the reproductive cycle of corals. Marine Pollution Bulletin 100: 13-33.

Jordan, L. K. B., K. W. Banks, L. E. Fisher, B. K. Walker, and D. S. Gilliam. 2010. Elevated sedimentation on coral reefs adjacent to a beach nourishment project. Marine Pollution Bulletin 60: 261-271.

Junjie, R. K., N. K. Browne, P. L. Erftemeijer, and P. A. Todd. 2014. Impacts of sediments on coral energetics: partitioning the effects of turbidity and settling particles. PloS One 9.

Kamarumtham, K., Z. Ahmad, N. H. Halid, S. Saad, M. F. Khodzori, M. H. Yusof, and M. F. M. Hanafiah. 2016. Diversity and distribution of coral lifeforms in Tioman Island. Transactions on Science and Technology 3: 367-373.

Khodzori, M. F. A., S. Saad, N. F. H. Nordin, M. F. Salleh, M. H. Rani, M. H. Yusof, and N. M. Noor. 2015. Diversity and distribution of Euphyllidae corals in Tioman Island: emphasis on the genetic variation of Euphyllia cristata. Jurnal Teknologi 77 (24): 17-22.

Khodzori, F. A., S. Saad, and N. Mohammadnoor. 2019. Coral community structure in Payar Island Marine Park, Malaysia. Journal of Sustainability Science and Management 14: 29-39.

Khodzori, F. A., S. Saad, N. N. Mansor, N. A. N. M. Nasir, N. N. A. Khalid, and F. Z. Rawi. 2021. Pathogenic Vibrio spp. identified for white syndrome coral disease inTioman Island Marine Park, Malaysia. Malaysian Journal of Microbiology 17: 69-79.

Kohler, K. E., and S. M. Gill. 2006. Coral Point Count with Excel extensions (CPCe): A visual basic program for the determination of coral and substrate coverage using random point count methodology. Computers \& Geosciences 32: 1259-1269.

Lau, C. M., K. Alfian, A. Adzis, Y. A. Affendi, J. Hyde, A. Chelliah, Y. S. Leong, Y. L. Low, M. Yusop, P. Asma, and V. T. Leong. 2019. Tracing coral reefs: a citizen science approach in mapping coral reefs to enhance 
marine park management strategies. Frontiers in $\mathrm{Ma}$ rine Science 6: 539.

Lee, J. N., and C. A. R. Mohamed. 2011. Accumulation of settling particles in some coral reef areas of Peninsular Malaysia. Sains Malaysiana 40: 549-554.

Liew, H. C., Y. S. Hii, Z. Bachok, K. Ibrahim, S. Wagiman, A. A. Chan, and A. Said. 2012. A guide to collecting digital videos for coral reef surveys and monitoring purposes. Putrajaya: Department of Marine Parks Malaysia.

Lilliefors, H. W. 1967. On the Kolmogorov-Smirnov test for normality with mean and variance unknown. Journal of the American statistical Association 62: 399-402.

Madin, J. S., and S. R. Connolly. 2006. Ecological consequences of major hydrodynamic disturbances on coral reefs. Nature 444: 477-480.

Muko, S., K. Kawasaki, K. Sakai, F. Takasu, and N. Shigesada. 2000. Morphological plasticity in the coral Porites sillimaniani and its adaptive significance. Bulletin of Marine Science 66: 225-239.

Ng, P. K. L., H. S. Yong, and N. S. Sodhi. 1999. Biodiversity research on Pulau Tioman, Peninsular Malaysia: A historical perspective. The Raffles Bulletin of Zoology 6: 5-10.

Omar, S. I., A. G. Othman, B. Mohamed, and A. Bahauddin. 2015. Coastal resort life cycle: An overview of Tioman Island, Malaysia. Tourism Planning \& Development 12: 266-280.

Polónia, A. R. M., D. F. R. Cleary, N. J. de Voogd, W. Renema, B. W. Hoeksema, A. Martins, and N. C. M. Gomes. 2015. Habitat and water quality variables as predictors of community composition in an Indonesian coral reef: a multi-taxon study in the Spermonde Archipelago. Science of the Total Environment 537: 139-151.

Reef Check Malaysia. 2018. Status of Coral Reefs in Malaysia 2017. Reef Check Malaysia Survey Report, Reef Check Malaysia.

Saad, S., and F. A. Khodzori. 2017. Species diversity and abundance of Euphylliidae (Cnidaria: Anthozoa: Scleractinia) corals in Tioman, Redang and Payar Islands, Peninsular Malaysia. Borneo Journal of Marine Science and Aquaculture 1: 51-56.

Saad, S., Z. Ahmad, M. H. Rani, M. F. A. Khodzori, M. H. Yusof, N. M. Noor, and Y. Mukai. 2015. Assessing the potential of mangrove educotourism to marine protected area: a case of Tioman and Tulai Islands, Pahang, Malaysia. Natural Resources 6: 442.

Safuan, M., W. H. Boo, H. Y. Siang, L. H. Chark, and Z. Bachok. 2015. Optimization of coral video transect technique for coral reef survey: Comparison with intercept transect technique. Open Journal of Marine Science 5: 379.

Shahbudin, S., K. F. Akmal, S. Faris, M. N. Normawaty, and Y. Mukai. 2017. Current status of coral reefs in Tioman Island, Peninsular Malaysia. Turkish Journal of Zoology 41: 294-305.

Shapiro, S. S., and R. S. Francia. 1972. An approximate analysis of variance test for normality. Journal of the American Statistical Association 67: 215-216.

Tan, C. H., and S. F. Heron. 2011. First observed severe mass bleaching in Malaysia, Greater Coral Triangle. Galaxea. Journal of Coral Reef Studies 13: 27-28.

Toda, T., T. Okashita, T. Maekawa, B. A. A. K. Alfian, M. K. M. Rajuddin, R. Nakajima, W. Chen, K. T. Takahashi, B. H. R. Othman, and M. Terazaki. 2007. Community structures of coral reefs around Peninsular Malaysia. Journal of Oceanography 63: 113-123.

Veron, J. E. N. 2000. Corals of the World. Volumes 1-3. Australia: Australian Institute of Marine Science, Townsville.

Veron, J. E., L. M. Devantier, E. Turak, A. L. Green, S. Kininmonth, M. Stafford-Smith, and N. Peterson. 2009. Delineating the coral triangle. Galaxea, Journal of Coral Reef Studies 11: 91-100.

Veron, J., M. Stafford-Smith, L. DeVantier, and E. Turak. 2015. Overview of distribution patterns of zooxanthellate Scleractinia. Frontiers in Marine Science 1: 81.

Webler, T., and K. Jakubowski. 2016. Mitigating damaging behaviors of snorkelers to coral reefs in Puerto Rico through a pre-trip media-based intervention. Biological Conservation 197: 223-228.

Wielgus, J., N. E. Chadwick-Furman, and Z. Dubinsky. 2004. Coral cover and partial mortality on anthropogenically impacted coral reefs at Eilat, northern Red Sea. Marine Pollution Bulletin 48: 248-253.

Zakariah, Z. M., A. R. Ahmad, T. K. Hooi, M. N. Barison, and N. A. Yusoff. 2007. Coral reefs in the coastal waters of the south china sea-Malaysia. National report, Ministry of Natural Resources and Environment, Malaysia.

Zawada, K. J., J. S. Madin, A. H. Baird, T. C. Bridge, and M. Dornelas. 2019. Morphological traits can track coral reef responses to the Anthropocene. Functional Ecology 33: 962-975. 
Supplementary Table 1. The scleractinian coral species at 20 reef sites in TIMP. Species were identified following the current taxonomic revisions and descriptions. Symbol $\mathrm{x}$ indicates the species occurrence, while a indicates the most common species $(n \geq 17)$ and $b$ the least common species $(n \leq 3)$.

\begin{tabular}{|c|c|c|c|c|c|c|c|c|c|c|c|c|c|c|c|c|c|c|c|c|c|}
\hline \multirow{2}{*}{ No. } & \multirow{2}{*}{ Scleractinian coral species } & \multicolumn{6}{|c|}{ East coast zone (TE) } & \multicolumn{6}{|c|}{ West coast zone (TW) } & \multicolumn{8}{|c|}{ Isolated zone (TI) } \\
\hline & & 1 & 2 & 3 & 4 & 5 & 6 & 1 & 2 & 3 & 4 & 5 & 6 & 1 & 2 & 3 & 4 & 5 & 6 & 7 & 8 \\
\hline & Acroporidae & & & & & & & & & & & & & & & & & & & & \\
\hline 1 & Acropora abrolhosensis ${ }^{\mathrm{b}}$ & & & & & & & & & & & & & $\mathrm{x}$ & & & & & & & \\
\hline 2 & Acropora anthocersis & $\mathbf{x}$ & & & & $\mathrm{x}$ & $\mathrm{x}$ & $\mathrm{x}$ & & & & $\mathrm{x}$ & & & & & & & & & \\
\hline 3 & Acropora austera $^{\mathrm{b}}$ & & & & & $\mathrm{x}$ & & $\mathrm{x}$ & & & & & & & $\mathrm{x}$ & & & & & & \\
\hline 4 & Acropora carduus ${ }^{\mathrm{b}}$ & & & & & $\mathrm{x}$ & & $\mathrm{x}$ & & & & & & & & & & & & & \\
\hline 5 & Acropora cerealis & $\mathbf{x}$ & $\mathbf{x}$ & $\mathbf{x}$ & & $\mathrm{x}$ & $\mathrm{x}$ & $\mathrm{x}$ & & & & & & & & $\mathrm{x}$ & & & $\mathrm{x}$ & & $\mathbf{x}$ \\
\hline 6 & Acropora clathrata & $\mathbf{x}$ & & $\mathrm{x}$ & & $\mathrm{x}$ & & $\mathrm{x}$ & $\mathrm{x}$ & $\mathrm{x}$ & & & & & & & $\mathrm{x}$ & & & & \\
\hline 7 & Acropora cytherea ${ }^{\text {a }}$ & $\mathbf{x}$ & $\mathbf{x}$ & $\mathbf{x}$ & $\mathbf{x}$ & $\mathbf{x}$ & $\mathbf{x}$ & $\mathbf{x}$ & $\mathbf{x}$ & $\mathbf{x}$ & $\mathbf{x}$ & $\mathrm{x}$ & $\mathrm{x}$ & $\mathrm{x}$ & $\mathrm{x}$ & $\mathrm{x}$ & $\mathrm{x}$ & $\mathrm{x}$ & $\mathrm{x}$ & & $\mathrm{x}$ \\
\hline 8 & Acropora digitifera & $\mathbf{x}$ & $\mathbf{x}$ & $\mathbf{x}$ & & $\mathrm{x}$ & $\mathrm{x}$ & $\mathrm{x}$ & & $\mathrm{x}$ & & $\mathrm{x}$ & & & & & & & & & \\
\hline 9 & Acropora divaricata & & & & & $\mathrm{x}$ & & $\mathrm{x}$ & & & & & & $\mathrm{x}$ & $\mathrm{x}$ & & & $\mathrm{x}$ & & & \\
\hline 10 & Acropora donei $^{\mathrm{b}}$ & & & & & & & & & & & & & $\mathrm{x}$ & & & & & & & \\
\hline 11 & Acropora florida & $\mathbf{x}$ & & $\mathrm{x}$ & $\mathrm{x}$ & $\mathrm{x}$ & $\mathrm{x}$ & $\mathrm{x}$ & $\mathrm{x}$ & $\mathrm{x}$ & & & & $\mathrm{x}$ & & $\mathrm{x}$ & $\mathrm{x}$ & $\mathrm{x}$ & & $\mathrm{x}$ & $\mathbf{x}$ \\
\hline 12 & Acropora gemmifera & $\mathbf{x}$ & $\mathbf{x}$ & $\mathbf{x}$ & $\mathbf{x}$ & $\mathbf{x}$ & $\mathbf{x}$ & $\mathbf{x}$ & $\mathbf{x}$ & & $\mathrm{x}$ & $\mathrm{x}$ & $\mathrm{x}$ & & & & & $\mathrm{x}$ & & & \\
\hline 13 & Acropora grandis ${ }^{\mathrm{b}}$ & $\mathrm{x}$ & & & & & & & & & & & & $\mathrm{x}$ & & & & $\mathrm{x}$ & & & \\
\hline 14 & Acropora hoeksemai ${ }^{\mathrm{b}}$ & & & & & & & & $\mathrm{x}$ & & $\mathrm{x}$ & & & & & & & & & & \\
\hline 15 & Acropora horrida ${ }^{\mathrm{b}}$ & & & & & & $\mathrm{x}$ & & & & & $\mathrm{x}$ & & & & & & & & $\mathrm{x}$ & \\
\hline 16 & Acropora humilis ${ }^{\mathrm{b}}$ & & & $\mathrm{x}$ & & & & & & & & & & & & & & & & & \\
\hline 17 & Acropora hyacinthus & $\mathbf{x}$ & $\mathbf{x}$ & $\mathbf{x}$ & $\mathbf{x}$ & $\mathbf{x}$ & $\mathbf{x}$ & $\mathbf{x}$ & $\mathbf{x}$ & $\mathbf{x}$ & $\mathbf{x}$ & $\mathbf{x}$ & & $\mathrm{x}$ & & $\mathrm{x}$ & $\mathrm{x}$ & $\mathrm{x}$ & $\mathrm{x}$ & & \\
\hline 18 & Acropora Indonesia ${ }^{\mathrm{b}}$ & & & & & & & & & & & & $\mathrm{x}$ & & & & & & & & \\
\hline 19 & Acropora insignis ${ }^{\mathrm{b}}$ & & & & & & & & & & & & & & & $\mathrm{x}$ & & & & & \\
\hline 20 & Acropora intermedia ${ }^{\text {a }}$ & $\mathrm{x}$ & $\mathrm{x}$ & $\mathrm{x}$ & $\mathrm{x}$ & $\mathrm{x}$ & $\mathrm{x}$ & $\mathrm{x}$ & $\mathrm{x}$ & $\mathrm{x}$ & $\mathrm{x}$ & & $\mathrm{x}$ & $\mathrm{x}$ & $\mathrm{x}$ & $\mathrm{x}$ & $\mathrm{x}$ & $\mathrm{x}$ & $\mathrm{x}$ & $\mathrm{x}$ & $\mathrm{x}$ \\
\hline 21 & Acropora latistella & $\mathbf{x}$ & & $\mathrm{x}$ & & $\mathrm{x}$ & $\mathrm{x}$ & $\mathrm{x}$ & & & & & & & & $\mathrm{x}$ & & & & & \\
\hline 22 & Acropora loripes & & $\mathrm{x}$ & $\mathrm{x}$ & $\mathrm{x}$ & & $\mathrm{x}$ & & $\mathrm{x}$ & & & & $\mathrm{x}$ & & & & & & & & \\
\hline 23 & Acropora microphthalma & $\mathbf{x}$ & & $\mathrm{x}$ & & $\mathrm{x}$ & $\mathrm{x}$ & $\mathrm{x}$ & $\mathrm{x}$ & $\mathrm{x}$ & & & & $\mathrm{x}$ & $\mathrm{x}$ & $\mathrm{x}$ & $\mathbf{x}$ & $\mathbf{x}$ & $\mathbf{x}$ & $\mathbf{x}$ & $\mathbf{x}$ \\
\hline 24 & Acropora millepora & $\mathbf{x}$ & $\mathbf{x}$ & $\mathbf{x}$ & $\mathbf{x}$ & $\mathbf{x}$ & $\mathbf{x}$ & $\mathbf{x}$ & $\mathbf{x}$ & $\mathbf{x}$ & $\mathbf{x}$ & $\mathbf{x}$ & $\mathbf{x}$ & $\mathbf{x}$ & $\mathrm{x}$ & $\mathrm{x}$ & & & & & \\
\hline 25 & Acropora monticulosa ${ }^{\mathrm{b}}$ & & & & & $\mathrm{x}$ & & & & & & & & & & & & & & & \\
\hline 26 & Acropora muricata ${ }^{\mathrm{a}}$ & $\mathbf{x}$ & $\mathbf{x}$ & $\mathbf{x}$ & $\mathbf{x}$ & $\mathbf{x}$ & $\mathbf{x}$ & $\mathbf{x}$ & $\mathbf{x}$ & $\mathbf{x}$ & $\mathbf{x}$ & $\mathbf{x}$ & $\mathbf{x}$ & $\mathbf{x}$ & $\mathbf{x}$ & $\mathbf{x}$ & $\mathbf{x}$ & $\mathbf{x}$ & $\mathbf{x}$ & $\mathbf{x}$ & $\mathbf{x}$ \\
\hline 27 & Acropora nasuta & $\mathbf{x}$ & $\mathbf{x}$ & $\mathbf{x}$ & $\mathbf{x}$ & $\mathbf{x}$ & $\mathbf{x}$ & $\mathbf{x}$ & $\mathbf{x}$ & $\mathrm{x}$ & $\mathrm{x}$ & $\mathrm{x}$ & $\mathrm{x}$ & $\mathrm{x}$ & & $\mathrm{x}$ & & & $\mathrm{x}$ & & \\
\hline 28 & Acropora plana $^{\mathrm{b}}$ & $\mathbf{x}$ & & & & & & & & & & & & $\mathrm{x}$ & $\mathrm{x}$ & & & & & & \\
\hline 29 & Acropora robusta ${ }^{\mathrm{b}}$ & & & & $\mathrm{x}$ & $\mathrm{x}$ & $\mathrm{x}$ & & & & & & & & & & & & & & \\
\hline 30 & Acropora secale ${ }^{\mathrm{b}}$ & & & $\mathrm{x}$ & & $\mathrm{x}$ & & & & & & & & & & & & & & & \\
\hline 31 & Acropora selago & $\mathbf{x}$ & $\mathbf{x}$ & $\mathbf{x}$ & & $\mathrm{x}$ & $\mathrm{x}$ & $\mathrm{x}$ & $\mathrm{x}$ & $\mathrm{x}$ & $\mathrm{x}$ & $\mathrm{x}$ & $\mathrm{x}$ & $\mathrm{x}$ & & $\mathrm{x}$ & & $\mathrm{x}$ & $\mathrm{x}$ & & \\
\hline 32 & Acropora solitaryensis ${ }^{\mathrm{b}}$ & & & & & & & & & & $\mathrm{x}$ & & & & & & & & & & \\
\hline 33 & Acropora spicifera & $\mathrm{x}$ & & & & $\mathrm{x}$ & & $\mathrm{x}$ & & & & & & & & & $\mathrm{x}$ & & & & \\
\hline 34 & Acropora tenuis & $\mathbf{x}$ & $\mathbf{x}$ & $\mathbf{x}$ & & $\mathrm{x}$ & $\mathrm{x}$ & $\mathrm{x}$ & $\mathrm{x}$ & $\mathrm{x}$ & $\mathrm{x}$ & $\mathrm{x}$ & $\mathrm{x}$ & $\mathrm{x}$ & & $\mathrm{x}$ & & $\mathrm{x}$ & $\mathrm{x}$ & $\mathrm{x}$ & \\
\hline 35 & Acropora valenciennesi & & & & & $\mathrm{x}$ & & $\mathrm{x}$ & & $\mathrm{x}$ & & & & & & & & $\mathrm{x}$ & & & \\
\hline 36 & Alveopora spongiosa ${ }^{\mathrm{b}}$ & $\mathbf{x}$ & & & & $\mathrm{x}$ & & & & & & & & & & & & & & & \\
\hline 37 & Anacropora matthai ${ }^{\mathrm{b}}$ & & & & & & & & & & & & & $\mathrm{x}$ & & & & & & & \\
\hline 38 & Anacropora forbesi ${ }^{\mathrm{b}}$ & & & & & $\mathrm{x}$ & & & & & & & & & $\mathrm{x}$ & & & & & & \\
\hline 39 & Anacropora puertogalerae ${ }^{\mathrm{b}}$ & & & & & & & $\mathrm{x}$ & & & & & & & $\mathrm{x}$ & & & & & & \\
\hline 40 & Astreopora gracilis & $\mathbf{x}$ & $\mathbf{x}$ & $\mathbf{x}$ & & $\mathrm{x}$ & $\mathrm{x}$ & $\mathrm{x}$ & $\mathrm{x}$ & & & & & & $\mathrm{x}$ & & & & & & \\
\hline 41 & Astreopora myriophthalma & $\mathbf{x}$ & $\mathbf{x}$ & $\mathbf{x}$ & $\mathbf{x}$ & $\mathbf{x}$ & $\mathbf{x}$ & $\mathbf{x}$ & $\mathbf{x}$ & $\mathbf{x}$ & & & & & $\mathrm{x}$ & $\mathrm{x}$ & $\mathrm{x}$ & & & & \\
\hline 42 & Astreopora ocellata $^{\mathrm{b}}$ & & & & & & & $\mathrm{x}$ & & & $\mathrm{x}$ & & & & & & & & & & \\
\hline 43 & Isopora bruggemanni & & & & & $\mathrm{x}$ & & $\mathrm{x}$ & $\mathrm{x}$ & $\mathrm{x}$ & $\mathrm{x}$ & $\mathrm{x}$ & $\mathrm{x}$ & & $\mathrm{x}$ & $\mathrm{x}$ & & & & & \\
\hline 44 & Isopora cuneata $^{\mathrm{b}}$ & & & & & $\mathrm{x}$ & & & & & & & & & & & & & & & \\
\hline 45 & Isopora palifera & & & & $\mathrm{x}$ & $\mathrm{x}$ & $\mathrm{x}$ & & & & & & & & $\mathrm{x}$ & & & & & & \\
\hline 46 & Montipora aequituberculata ${ }^{\text {a }}$ & $\mathbf{x}$ & $\mathbf{x}$ & $\mathbf{x}$ & $\mathbf{x}$ & $\mathbf{x}$ & $\mathbf{x}$ & $\mathbf{x}$ & $\mathbf{x}$ & $\mathbf{x}$ & $\mathbf{x}$ & $\mathbf{x}$ & $\mathbf{x}$ & $\mathbf{x}$ & $\mathbf{x}$ & $\mathbf{x}$ & $\mathbf{x}$ & $\mathbf{x}$ & $\mathbf{x}$ & $\mathbf{x}$ & $\mathbf{x}$ \\
\hline 47 & Montipora altasepta ${ }^{\mathrm{b}}$ & & & & & & & & & & & & & & & $\mathrm{x}$ & & & & & \\
\hline 48 & Montipora cebuensis ${ }^{\mathrm{b}}$ & & $\mathrm{x}$ & & & & $\mathrm{x}$ & & & & & & & & $\mathrm{x}$ & & & & & & \\
\hline 49 & Montipora confusa ${ }^{\mathrm{b}}$ & $\mathbf{x}$ & & & & & & & & & & & & & & & & & & & \\
\hline 50 & Montipora crassituberculata $^{\mathrm{b}}$ & & & & & $\mathrm{x}$ & & & & & & & & $\mathrm{x}$ & & & & & & & \\
\hline
\end{tabular}




\begin{tabular}{|c|c|c|c|c|c|c|c|c|c|c|c|c|c|c|c|c|c|c|c|c|c|}
\hline \multirow{2}{*}{ No. } & \multirow{2}{*}{ Scleractinian coral species } & \multicolumn{6}{|c|}{ East coast zone (TE) } & \multicolumn{6}{|c|}{ West coast zone (TW) } & \multicolumn{8}{|c|}{ Isolated zone (TI) } \\
\hline & & 1 & 2 & 3 & 4 & 5 & 6 & 1 & 2 & 3 & 4 & 5 & 6 & 1 & 2 & 3 & 4 & 5 & 6 & 7 & 8 \\
\hline 51 & Montipora danae & & & & & $\mathrm{x}$ & $\mathrm{x}$ & $\mathrm{x}$ & & & & & & & $\mathrm{x}$ & & & $\mathrm{x}$ & & & \\
\hline 52 & Montipora delicatula ${ }^{\mathrm{b}}$ & & & & & $\mathrm{x}$ & & & & $\mathrm{x}$ & & & & $\mathrm{x}$ & & & & & & & \\
\hline 53 & Montipora efflorescens & $\mathbf{x}$ & $\mathbf{x}$ & $\mathbf{x}$ & $\mathbf{x}$ & & $\mathrm{x}$ & & & & $\mathrm{x}$ & & & $\mathrm{x}$ & $\mathrm{x}$ & $\mathrm{x}$ & & $\mathrm{x}$ & & & $\mathbf{x}$ \\
\hline 54 & Montipora foliosa ${ }^{a}$ & $\mathbf{x}$ & $\mathbf{x}$ & $\mathbf{x}$ & $\mathbf{x}$ & $\mathbf{x}$ & $\mathbf{x}$ & $\mathbf{x}$ & $\mathbf{x}$ & $\mathbf{x}$ & $\mathbf{x}$ & $\mathbf{x}$ & & $\mathrm{x}$ & $\mathrm{x}$ & $\mathrm{x}$ & $\mathrm{x}$ & & $\mathrm{x}$ & & $\mathbf{x}$ \\
\hline 55 & Montipora friabilis & & & & & $\mathrm{x}$ & & $\mathrm{x}$ & & $\mathrm{x}$ & & & & $\mathrm{x}$ & & & & & & & \\
\hline 56 & Montipora grisea & $\mathbf{x}$ & $\mathbf{x}$ & $\mathbf{x}$ & & $\mathrm{x}$ & & & & & & & & $\mathrm{x}$ & $\mathrm{x}$ & & & & & & \\
\hline 57 & Montipora hispida ${ }^{\mathrm{b}}$ & & & & & $\mathrm{x}$ & & & $\mathrm{x}$ & & & & & $\mathrm{x}$ & & & & & & & \\
\hline 58 & Montipora informis a & $\mathbf{x}$ & $\mathbf{x}$ & $\mathbf{x}$ & $\mathbf{x}$ & $\mathbf{x}$ & $\mathbf{x}$ & $\mathrm{x}$ & $\mathrm{x}$ & $\mathrm{x}$ & $\mathrm{x}$ & & $\mathrm{x}$ & $\mathrm{x}$ & $\mathrm{x}$ & $\mathrm{x}$ & & $\mathrm{x}$ & $\mathrm{x}$ & & $\mathbf{x}$ \\
\hline 59 & Montipora millepora & & $\mathrm{x}$ & $\mathrm{x}$ & $\mathrm{x}$ & $\mathrm{x}$ & & $\mathrm{x}$ & & & & & & & $\mathrm{x}$ & & & & & & \\
\hline 60 & Montipora monasteriata $^{\mathrm{b}}$ & $\mathbf{x}$ & $\mathbf{x}$ & & & $\mathrm{x}$ & & & & & & & & & & & & & & & \\
\hline 61 & Montipora stellata ${ }^{\mathrm{b}}$ & & & & & $\mathrm{x}$ & & & & & & & & & & & & & & $\mathrm{x}$ & \\
\hline 62 & Montipora tuberculosa & $\mathbf{x}$ & $\mathbf{x}$ & $\mathbf{x}$ & & $\mathrm{x}$ & & $\mathrm{x}$ & $\mathrm{x}$ & & $\mathrm{x}$ & & & $\mathrm{x}$ & $\mathrm{x}$ & & & $\mathrm{x}$ & & & \\
\hline 63 & Montipora turgescens & $\mathbf{x}$ & & $\mathrm{x}$ & $\mathrm{x}$ & $\mathrm{x}$ & $\mathrm{x}$ & & & & & & $\mathrm{x}$ & & $\mathrm{x}$ & & & & & & \\
\hline 64 & Montipora undata & $\mathbf{x}$ & & $\mathrm{x}$ & $\mathrm{x}$ & & & $\mathrm{x}$ & $\mathrm{x}$ & $\mathrm{x}$ & & $\mathrm{x}$ & & & & $\mathrm{x}$ & & & & & $\mathbf{x}$ \\
\hline 65 & Montipora venosa ${ }^{b}$ & & & & & & & & & $\mathrm{x}$ & & & & & & & & & & & \\
\hline 66 & Montipora verrucolosus ${ }^{b}$ & $\mathbf{x}$ & & & & & & & & & & & & & & & & & & & \\
\hline 67 & Montipora verrucosa & $\mathrm{x}$ & & $\mathrm{x}$ & & $\mathrm{x}$ & & $\mathrm{x}$ & & & & & & & $\mathrm{x}$ & & & & & & $\mathbf{x}$ \\
\hline \multirow[t]{2}{*}{68} & Montipora vietnamensis & & & $\mathrm{x}$ & & $\mathrm{x}$ & & $\mathrm{x}$ & & & & & & $\mathrm{x}$ & & & & & & & \\
\hline & Agariciidae & & & & & & & & & & & & & & & & & & & & \\
\hline 69 & Coeloseris mayeri ${ }^{\mathrm{b}}$ & & & & & $\mathrm{x}$ & $\mathrm{x}$ & & & & & & & $\mathrm{x}$ & & & & & & & \\
\hline 70 & Gardineroseris planulata & $\mathbf{x}$ & & & & $\mathrm{x}$ & $\mathrm{x}$ & & & $\mathrm{x}$ & & & & $\mathrm{x}$ & $\mathrm{x}$ & $\mathrm{x}$ & & $\mathrm{x}$ & & & \\
\hline 71 & Leptoseris mycetoseroides ${ }^{b}$ & & & & & & & & & & & & & & & & & $\mathrm{x}$ & & & \\
\hline 72 & Leptoseris scabra ${ }^{b}$ & & & & & $\mathrm{x}$ & & & & & & & & & & & & & & & \\
\hline 73 & Pavona cactus & & & $\mathrm{x}$ & & & $\mathrm{x}$ & & $\mathrm{x}$ & $\mathrm{x}$ & $\mathrm{x}$ & $\mathrm{x}$ & & & & $\mathrm{x}$ & $\mathrm{x}$ & $\mathrm{x}$ & $\mathrm{x}$ & & \\
\hline 74 & Pavona clavus & & & & $\mathrm{x}$ & & & $\mathrm{x}$ & & & & & & & & $\mathrm{x}$ & $\mathrm{x}$ & & & $\mathrm{x}$ & \\
\hline 75 & Pavona danai & $\mathbf{x}$ & $\mathbf{x}$ & $\mathbf{x}$ & & & $\mathrm{x}$ & & & & & & & $\mathrm{x}$ & & $\mathrm{x}$ & & & & & \\
\hline 76 & Pavona decussata ${ }^{a}$ & $\mathbf{x}$ & $\mathbf{x}$ & $\mathbf{x}$ & $\mathbf{x}$ & $\mathbf{x}$ & $\mathbf{x}$ & $\mathbf{x}$ & $\mathbf{x}$ & $\mathbf{x}$ & $\mathbf{x}$ & $\mathbf{x}$ & & $\mathrm{x}$ & $\mathrm{x}$ & $\mathrm{x}$ & $\mathrm{x}$ & $\mathrm{x}$ & $\mathrm{x}$ & & \\
\hline 77 & Pavona explanulata & & & & & & & & & & & & & $\mathrm{x}$ & $\mathrm{x}$ & & & $\mathrm{x}$ & $\mathrm{x}$ & & \\
\hline 78 & Pavona frondifera & $\mathbf{x}$ & $\mathbf{x}$ & $\mathbf{x}$ & & $\mathrm{x}$ & $\mathrm{x}$ & & & $\mathrm{x}$ & & $\mathrm{x}$ & & & & $\mathrm{x}$ & $\mathrm{x}$ & & & & $\mathbf{x}$ \\
\hline 79 & Pavona venosa & $\mathbf{x}$ & & $\mathrm{x}$ & & & $\mathrm{x}$ & & & & & & & & & & $\mathrm{x}$ & & & & \\
\hline \multirow[t]{2}{*}{80} & Pavona varians & $\mathbf{x}$ & & & $\mathrm{x}$ & & & & $\mathrm{x}$ & $\mathrm{x}$ & & & & $\mathrm{x}$ & & & & $\mathrm{x}$ & & & $\mathrm{x}$ \\
\hline & \multicolumn{21}{|l|}{ Astrocoeniidae } \\
\hline \multirow[t]{2}{*}{81} & Stylocoeniella guentheri ${ }^{\mathrm{b}}$ & & & & $\mathrm{x}$ & $\mathrm{x}$ & & & & & & & & & & & & & & & \\
\hline & \multicolumn{21}{|l|}{ Coscinaraeidae } \\
\hline 82 & Coscinaraea columna & & $\mathrm{x}$ & $\mathrm{x}$ & & & & & & & & $\mathrm{x}$ & & & & & & $\mathrm{x}$ & & & \\
\hline 83 & Coscinaraea exesa ${ }^{\mathrm{b}}$ & & & & & & & & $\mathrm{x}$ & & & & & & & & & & & & \\
\hline & Dendrophylliidae & & & & & & & & & & & & & & & & & & & & \\
\hline 84 & Turbinaria frondens ${ }^{\mathrm{b}}$ & & & & & $\mathrm{x}$ & & $\mathrm{x}$ & & & & & & & $\mathrm{x}$ & & & & & & \\
\hline 85 & Turbinaria irregularis ${ }^{\mathrm{b}}$ & & & & & & $\mathrm{x}$ & & & & & & & & & & & & & & \\
\hline 86 & Turbinaria mesenterina $^{b}$ & & & & & $\mathrm{x}$ & & & & & & & & & $\mathrm{x}$ & $\mathrm{x}$ & & & & & \\
\hline 87 & Turbinaria peltata & & & & & & & $\mathrm{x}$ & $\mathrm{x}$ & $\mathrm{x}$ & & & & & & & $\mathrm{x}$ & $\mathrm{x}$ & $\mathrm{x}$ & & \\
\hline 88 & Turbinaria reniformis ${ }^{\mathrm{b}}$ & & $x$ & & & & & & & & & & & & & & & & & & \\
\hline 89 & Turbinaria stellulata $^{\mathrm{b}}$ & & $\mathrm{x}$ & & $\mathrm{x}$ & $\mathrm{x}$ & & & & & & & & & & & & & & & \\
\hline & Diploastraeidae & & & & & & & & & & & & & & & & & & & & \\
\hline 90 & Diploastrea heliopora & $\mathbf{x}$ & $\mathbf{x}$ & $\mathbf{x}$ & $\mathbf{x}$ & $\mathbf{x}$ & $\mathbf{x}$ & $\mathbf{x}$ & $\mathbf{x}$ & & $\mathrm{x}$ & & & $\mathrm{x}$ & $\mathrm{x}$ & & & $\mathrm{x}$ & & & $\mathrm{x}$ \\
\hline & Euphylliidae & & & & & & & & & & & & & & & & & & & & \\
\hline 91 & Euphyllia ancora & & $\mathrm{x}$ & & & $\mathrm{x}$ & $\mathrm{x}$ & $\mathrm{x}$ & & & & & & $\mathrm{x}$ & & & & & & $\mathbf{x}$ & $\mathbf{x}$ \\
\hline 92 & Euphyllia cristata ${ }^{b}$ & & & & & & $\mathrm{x}$ & & & & & & & & & & & $\mathrm{x}$ & & & \\
\hline 93 & Euphyllia divisa & $\mathbf{x}$ & $\mathbf{x}$ & $\mathbf{x}$ & $\mathbf{x}$ & $\mathbf{x}$ & $\mathrm{x}$ & & & & $\mathrm{x}$ & & & $\mathrm{x}$ & & & & & & & \\
\hline 94 & Euphyllia glabrescens & $\mathbf{x}$ & & & & & $\mathrm{x}$ & & & $\mathrm{x}$ & & $\mathrm{x}$ & & $\mathrm{x}$ & & $\mathrm{x}$ & $\mathrm{x}$ & $\mathrm{x}$ & & $\mathrm{x}$ & \\
\hline 95 & Euphyllia yaeyamensis ${ }^{\mathrm{b}}$ & $\mathbf{x}$ & & $\mathrm{x}$ & & & & & & & & & & & & & & & & & \\
\hline 96 & Galaxea astreata & $\mathbf{x}$ & & $\mathrm{x}$ & & $\mathrm{x}$ & & & $\mathrm{x}$ & & $\mathrm{x}$ & & & $\mathrm{x}$ & & & & $\mathrm{x}$ & & $\mathrm{x}$ & \\
\hline 97 & 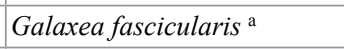 & $\mathbf{x}$ & $\mathbf{x}$ & $\mathbf{x}$ & $\mathbf{x}$ & $\mathbf{x}$ & $\mathbf{x}$ & $\mathbf{x}$ & $\mathbf{x}$ & $\mathbf{x}$ & $\mathbf{x}$ & $\mathbf{x}$ & $\mathbf{x}$ & $\mathbf{x}$ & $\mathbf{x}$ & $\mathbf{x}$ & $\mathbf{x}$ & $\mathbf{x}$ & $\mathbf{x}$ & $\mathbf{x}$ & $\mathbf{x}$ \\
\hline 98 & Pachyseris foliosa ${ }^{\mathrm{b}}$ & & & & & $\mathrm{x}$ & & & & & & & & & & & & $\mathrm{x}$ & & & \\
\hline 99 & Pachyseris gemmae & $\mathbf{x}$ & & & & $\mathrm{x}$ & & $\mathrm{x}$ & & & & & & & $\mathrm{x}$ & & & & & & \\
\hline
\end{tabular}




\begin{tabular}{|c|c|c|c|c|c|c|c|c|c|c|c|c|c|c|c|c|c|c|c|c|c|}
\hline \multirow{2}{*}{ No. } & \multirow{2}{*}{ Scleractinian coral species } & \multicolumn{6}{|c|}{ East coast zone (TE) } & \multicolumn{6}{|c|}{ West coast zone (TW) } & \multicolumn{8}{|c|}{ Isolated zone (TI) } \\
\hline & & 1 & 2 & 3 & 4 & 5 & 6 & 1 & 2 & 3 & 4 & 5 & 6 & 1 & 2 & 3 & 4 & 5 & 6 & 7 & 8 \\
\hline 100 & Pachyseris rugosa & $\mathbf{x}$ & $\mathbf{x}$ & $\mathbf{x}$ & $\mathbf{x}$ & $\mathbf{x}$ & $\mathbf{x}$ & $\mathbf{x}$ & $\mathbf{x}$ & $\mathbf{x}$ & $\mathbf{x}$ & & & $\mathrm{x}$ & $\mathrm{x}$ & & $\mathrm{x}$ & $\mathrm{x}$ & $\mathrm{x}$ & & \\
\hline \multirow[t]{2}{*}{101} & Pachyseris speciosa & $\mathbf{x}$ & $\mathbf{x}$ & $\mathbf{x}$ & $\mathbf{x}$ & $\mathbf{x}$ & $\mathbf{x}$ & $\mathbf{x}$ & & $x$ & & $x$ & $\mathrm{x}$ & $\mathrm{x}$ & $\mathrm{x}$ & $\mathrm{x}$ & & $\mathrm{x}$ & $\mathrm{x}$ & & $\mathrm{x}$ \\
\hline & Fungiidae & & & & & & & & & & & & & & & & & & & & \\
\hline 102 & Ctenactis albitentaculata $^{\mathrm{b}}$ & & & & & & & & & $\mathrm{x}$ & & & & & & $\mathrm{x}$ & & & & & \\
\hline 103 & Ctenactis crassa & & $\mathrm{x}$ & & & & & & & $\mathrm{x}$ & & & & & & & $\mathrm{x}$ & & & & $\mathbf{x}$ \\
\hline 104 & Ctenactis echinata & & & & & $\mathrm{x}$ & $\mathrm{x}$ & $\mathrm{x}$ & & $\mathrm{x}$ & $\mathrm{x}$ & $\mathrm{x}$ & & $\mathrm{x}$ & $\mathrm{x}$ & $\mathrm{x}$ & $\mathrm{x}$ & & & & \\
\hline 105 & Cycloseris costulata ${ }^{\mathrm{b}}$ & & & & & & & $\mathrm{x}$ & & & & & & & & $\mathrm{x}$ & $\mathrm{x}$ & & & & \\
\hline 106 & Cycloseris somervillei ${ }^{\mathrm{b}}$ & & & & & $\mathrm{x}$ & & & & & & & & & & & $\mathrm{x}$ & & & & \\
\hline 107 & Danafungia horrida ${ }^{\mathrm{b}}$ & & & & & & & & & & & & & & & $\mathrm{x}$ & & & & & $\mathbf{x}$ \\
\hline 108 & Fungia fungites ${ }^{\mathrm{a}}$ & $\mathbf{x}$ & $\mathbf{x}$ & $\mathbf{x}$ & $\mathbf{x}$ & $\mathbf{x}$ & $\mathbf{x}$ & $\mathbf{x}$ & $\mathbf{x}$ & $\mathbf{x}$ & $\mathbf{x}$ & $\mathbf{x}$ & $\mathrm{x}$ & $\mathrm{x}$ & $\mathrm{x}$ & $\mathrm{x}$ & $\mathrm{x}$ & & $\mathbf{x}$ & $\mathbf{x}$ & $\mathbf{x}$ \\
\hline 109 & Heliofungia actiniformis ${ }^{\mathrm{b}}$ & & & & & & & & & & & & & & & & & & $\mathbf{x}$ & $\mathbf{x}$ & $\mathbf{x}$ \\
\hline 110 & Herpolitha limax & & & $\mathrm{x}$ & & & & & $\mathrm{x}$ & $\mathrm{x}$ & & $\mathrm{x}$ & & & $\mathrm{x}$ & $\mathrm{x}$ & $\mathrm{x}$ & $\mathrm{x}$ & & & \\
\hline 111 & Lithophyllon concinna & & $\mathrm{x}$ & $\mathrm{x}$ & & $\mathrm{x}$ & $\mathrm{x}$ & $\mathrm{x}$ & $\mathrm{x}$ & $\mathrm{x}$ & $\mathrm{x}$ & $\mathrm{x}$ & & $\mathrm{x}$ & $\mathrm{x}$ & $\mathrm{x}$ & $\mathrm{x}$ & & $\mathrm{x}$ & & \\
\hline 112 & Lithophyllon repanda & $\mathbf{x}$ & $\mathbf{x}$ & $\mathbf{x}$ & & & $\mathrm{x}$ & & $\mathrm{x}$ & $\mathrm{x}$ & & & & & $\mathrm{x}$ & $\mathrm{x}$ & $\mathrm{x}$ & & & $\mathbf{x}$ & $\mathbf{x}$ \\
\hline 113 & Lithophyllon scabra ${ }^{\mathrm{b}}$ & & & & & & $\mathrm{x}$ & & & & & & & $\mathrm{x}$ & & $\mathrm{x}$ & & & & & \\
\hline 114 & Lithophyllon undulatum ${ }^{\mathrm{b}}$ & & & $\mathrm{x}$ & & $\mathrm{x}$ & & & & & & $\mathrm{x}$ & & & & & & & & & \\
\hline 115 & Lobactis scutaria $^{\text {b }}$ & & & $\mathrm{x}$ & & & & & & $\mathrm{x}$ & & & & & & & & & & & \\
\hline 116 & Pleuractis granulosa & $\mathbf{x}$ & & & & $\mathrm{x}$ & $\mathrm{x}$ & $\mathrm{x}$ & & $\mathrm{x}$ & & $\mathrm{x}$ & & $\mathrm{x}$ & $\mathrm{x}$ & $\mathrm{x}$ & $\mathrm{x}$ & & & $\mathrm{x}$ & \\
\hline 117 & Pleuractis gravis ${ }^{\mathrm{b}}$ & & & & & & & & & & & & & & & $\mathrm{x}$ & & & & & \\
\hline 118 & Pleuractis moluccensis & & & & & & & & & $\mathrm{x}$ & & $\mathrm{x}$ & & & & & $\mathrm{x}$ & & & & $\mathbf{x}$ \\
\hline 119 & Pleuractis paumotensis & & & & & & & & & $\mathrm{x}$ & & $\mathrm{x}$ & & & $\mathrm{x}$ & $\mathrm{x}$ & $\mathrm{x}$ & & & $\mathrm{x}$ & $\mathrm{x}$ \\
\hline 120 & Pleuractis seychellensis ${ }^{\mathrm{b}}$ & & & & & & & & & & & & & & & $\mathrm{x}$ & & & & & \\
\hline 121 & Podabacia crustacea ${ }^{\text {b }}$ & $\mathbf{x}$ & & & & & & & & & & & & & & & & & & & \\
\hline 122 & Podabacia motuporensis ${ }^{\mathrm{b}}$ & $\mathbf{x}$ & & & & & & & $\mathrm{x}$ & & & & & & & & & & & & \\
\hline 123 & Polyphyllia talpina & $\mathbf{x}$ & & $\mathrm{x}$ & & $\mathrm{x}$ & $\mathrm{x}$ & $\mathrm{x}$ & $\mathrm{x}$ & $\mathrm{x}$ & & $\mathrm{x}$ & & $\mathrm{x}$ & $\mathrm{x}$ & $\mathrm{x}$ & $\mathrm{x}$ & $\mathrm{x}$ & & & \\
\hline 124 & Sandalolitha dentata & $\mathbf{x}$ & & & $\mathrm{x}$ & $\mathrm{x}$ & $\mathrm{x}$ & $\mathrm{x}$ & & & & & & & $\mathrm{x}$ & $\mathrm{x}$ & $\mathrm{x}$ & & & & \\
\hline \multirow[t]{2}{*}{125} & Sandalolitha robusta & $\mathbf{x}$ & $\mathbf{x}$ & $\mathbf{x}$ & $\mathbf{x}$ & $\mathbf{x}$ & $\mathbf{x}$ & & & $\mathrm{x}$ & & $\mathrm{x}$ & $\mathrm{x}$ & & $\mathrm{x}$ & $\mathrm{x}$ & $\mathrm{x}$ & $\mathrm{x}$ & & & \\
\hline & Lobophylliidae & & & & & & & & & & & & & & & & & & & & \\
\hline 126 & Acanthastrea brevis & $\mathbf{x}$ & & & & $\mathrm{x}$ & & & & & $\mathrm{x}$ & & & & & $\mathrm{x}$ & & & & & \\
\hline 127 & Acanthastrea echinata & $\mathbf{x}$ & $\mathbf{x}$ & $\mathbf{x}$ & & $\mathrm{x}$ & $\mathrm{x}$ & $\mathrm{x}$ & & & $\mathrm{x}$ & & & & $\mathrm{x}$ & $\mathrm{x}$ & & & $\mathrm{x}$ & & \\
\hline 128 & Acanthastrea hemprichi & $\mathbf{x}$ & $\mathrm{x}$ & $\mathrm{x}$ & $\mathrm{x}$ & & & $\mathrm{x}$ & & $\mathrm{x}$ & & & $x$ & $\mathrm{x}$ & $\mathrm{x}$ & & & $\mathrm{x}$ & & & \\
\hline 129 & Acanthastrea pachysepta ${ }^{\mathrm{b}}$ & $\mathbf{x}$ & & & & & & & & & & & & & & & & & & & \\
\hline 130 & Acanthastrea rotundoflora ${ }^{\mathrm{b}}$ & & $\mathrm{x}$ & & & & & & & & & & & & & & & & & & \\
\hline 131 & Acanthastrea subechinata ${ }^{b}$ & & & $\mathrm{x}$ & & & & & & & & & & & & & & & & & \\
\hline 132 & Echinophyllia aspera ${ }^{\mathrm{b}}$ & & & & & & & $\mathrm{x}$ & & & & & & & $\mathrm{x}$ & & & & & & $\mathbf{x}$ \\
\hline 133 & Echinophyllia orpheensis & $\mathbf{x}$ & $\mathrm{x}$ & $\mathrm{x}$ & $\mathrm{x}$ & $\mathrm{x}$ & $\mathrm{x}$ & & & & & $\mathrm{x}$ & $\mathrm{x}$ & $\mathrm{x}$ & & & & & & & \\
\hline 134 & Homophyllia australis ${ }^{\mathrm{b}}$ & & & & & & & & & & & & & & & & & $\mathrm{x}$ & & & \\
\hline 135 & Lobophyllia agaricia $^{\text {a }}$ & $\mathbf{x}$ & $\mathbf{x}$ & $\mathbf{x}$ & $\mathrm{x}$ & $\mathrm{x}$ & $\mathrm{x}$ & $\mathrm{x}$ & $\mathrm{x}$ & $\mathrm{x}$ & $\mathrm{x}$ & $\mathrm{x}$ & $\mathrm{x}$ & $\mathrm{x}$ & $\mathrm{x}$ & $\mathrm{x}$ & $\mathrm{x}$ & $\mathrm{x}$ & & & $\mathbf{x}$ \\
\hline 136 & Lobophyllia corymbosa & $\mathbf{x}$ & & & & & $\mathrm{x}$ & $\mathrm{x}$ & & & & & & $\mathrm{x}$ & & & $\mathrm{x}$ & & & & \\
\hline 137 & Lobophyllia flabelliformis & & & & & & $\mathrm{x}$ & & & & & $\mathrm{x}$ & & & $\mathrm{x}$ & & & $\mathrm{x}$ & & & $\mathbf{x}$ \\
\hline 138 & Lobophyllia hassi & $\mathbf{x}$ & $\mathbf{x}$ & $\mathbf{x}$ & & $\mathrm{x}$ & $\mathrm{x}$ & $\mathrm{x}$ & & $\mathrm{x}$ & & & & $\mathrm{x}$ & & & & & & & \\
\hline 139 & Lobophyllia hataii & $\mathbf{x}$ & $\mathbf{x}$ & $\mathbf{x}$ & $\mathbf{x}$ & $\mathbf{x}$ & $\mathrm{x}$ & $\mathrm{x}$ & $\mathrm{x}$ & & & & & $\mathrm{x}$ & $\mathrm{x}$ & & & $\mathrm{x}$ & & & \\
\hline 140 & Lobophyllia hemprichii & $\mathbf{x}$ & $\mathbf{x}$ & $\mathbf{x}$ & $\mathbf{x}$ & $\mathbf{x}$ & $\mathbf{x}$ & $\mathbf{x}$ & $\mathbf{x}$ & & $\mathrm{x}$ & $\mathrm{x}$ & & $\mathrm{x}$ & $\mathrm{x}$ & $\mathrm{x}$ & $\mathrm{x}$ & $\mathrm{x}$ & & & $\mathbf{x}$ \\
\hline 141 & Lobophyllia radians ${ }^{\text {a }}$ & $\mathbf{x}$ & $\mathbf{x}$ & $\mathbf{x}$ & $\mathbf{x}$ & $\mathbf{x}$ & $\mathbf{x}$ & $\mathbf{x}$ & $\mathbf{x}$ & $\mathrm{x}$ & & & $\mathrm{x}$ & $\mathrm{x}$ & $\mathrm{x}$ & $\mathrm{x}$ & $\mathrm{x}$ & $\mathrm{x}$ & & $\mathbf{x}$ & $\mathbf{x}$ \\
\hline 142 & Lobophyllia recta & $\mathbf{x}$ & $\mathbf{x}$ & $\mathbf{x}$ & $\mathbf{x}$ & $\mathbf{x}$ & $\mathbf{x}$ & $\mathbf{x}$ & $\mathrm{x}$ & & $\mathrm{x}$ & & & $\mathrm{x}$ & $\mathrm{x}$ & & & $\mathrm{x}$ & $\mathrm{x}$ & & $\mathbf{x}$ \\
\hline 143 & Lobophyllia robusta & $\mathbf{x}$ & $\mathbf{x}$ & $\mathbf{x}$ & $\mathbf{x}$ & $\mathbf{x}$ & $\mathbf{x}$ & $\mathbf{x}$ & & & $\mathrm{x}$ & $\mathrm{x}$ & & $\mathrm{x}$ & $\mathrm{x}$ & & & $\mathrm{x}$ & & & \\
\hline 144 & Lobophyllia valenciennesii ${ }^{\mathrm{b}}$ & & & & & $\mathrm{x}$ & & & & & & & & & $\mathrm{x}$ & & & $\mathrm{x}$ & & & \\
\hline 145 & Lobophyllia vitiensis ${ }^{\mathrm{b}}$ & & & & & $\mathrm{x}$ & & & & & & & & & & & & & & & \\
\hline 146 & Micromussa diminuta ${ }^{\mathrm{b}}$ & & & & & $\mathrm{x}$ & & & & & & & & & & & & & & & \\
\hline 147 & Micromussa lordhowensis ${ }^{\mathrm{b}}$ & $\mathbf{x}$ & & $\mathrm{x}$ & & & & & & & & & & & & & & & & & \\
\hline 148 & Micromussa multipunctata $^{\mathrm{b}}$ & & $\mathrm{x}$ & & & & & & & & & & & & & & & & & & \\
\hline \multirow[t]{2}{*}{149} & Oxypora lacera ${ }^{\text {b }}$ & & & & & $\mathrm{x}$ & & & & & & & & & & & & & & & \\
\hline & \multicolumn{21}{|l|}{ Merulinidae } \\
\hline 150 & Astrea curta & $\mathbf{x}$ & $\mathbf{x}$ & $\mathbf{x}$ & & $\mathrm{x}$ & & $\mathrm{x}$ & $\mathrm{x}$ & & $\mathrm{x}$ & & & $\mathrm{x}$ & $\mathrm{x}$ & $\mathrm{x}$ & & $\mathrm{x}$ & & $\mathbf{x}$ & $\mathbf{x}$ \\
\hline 151 & Coelastrea aspera & $\mathbf{x}$ & $\mathbf{x}$ & $\mathbf{x}$ & $\mathbf{x}$ & $\mathbf{x}$ & $\mathbf{x}$ & $\mathbf{x}$ & $\mathbf{x}$ & $\mathrm{x}$ & $\mathrm{x}$ & & X & $\mathrm{x}$ & $\mathrm{x}$ & $\mathrm{x}$ & & $\mathrm{x}$ & & & \\
\hline
\end{tabular}




\begin{tabular}{|c|c|c|c|c|c|c|c|c|c|c|c|c|c|c|c|c|c|c|c|c|c|}
\hline \multirow{2}{*}{ No. } & \multirow{2}{*}{ Scleractinian coral species } & \multicolumn{6}{|c|}{ East coast zone (TE) } & \multicolumn{6}{|c|}{ West coast zone (TW) } & \multicolumn{8}{|c|}{ Isolated zone (TI) } \\
\hline & & 1 & 2 & 3 & 4 & 5 & 6 & 1 & 2 & 3 & 4 & 5 & 6 & 1 & 2 & 3 & 4 & 5 & 6 & 7 & 8 \\
\hline 152 & Coelastrea palauensis & $\mathbf{x}$ & $\mathbf{x}$ & $\mathbf{x}$ & & $\mathrm{x}$ & & $\mathrm{x}$ & & & & & $\mathrm{x}$ & $\mathrm{x}$ & $\mathrm{x}$ & $\mathrm{x}$ & & $\mathrm{x}$ & & & \\
\hline 153 & Cyphastrea chalcidicum & $\mathbf{x}$ & $\mathbf{x}$ & $\mathbf{x}$ & & $\mathrm{x}$ & $\mathrm{x}$ & $\mathrm{x}$ & $\mathrm{x}$ & & & & & $\mathrm{x}$ & $\mathrm{x}$ & $\mathrm{x}$ & & & & & \\
\hline 154 & Cyphastrea microphthalma & $\mathbf{x}$ & $\mathbf{x}$ & $\mathbf{x}$ & $\mathbf{x}$ & $\mathbf{x}$ & $\mathbf{x}$ & & $\mathrm{x}$ & & $\mathrm{x}$ & & & $\mathrm{x}$ & $\mathrm{x}$ & $\mathrm{x}$ & $\mathrm{x}$ & $\mathrm{x}$ & & & $\mathbf{x}$ \\
\hline 155 & Cyphastrea serailia & $\mathbf{x}$ & $\mathbf{x}$ & $\mathbf{x}$ & $\mathbf{x}$ & $\mathbf{x}$ & $\mathbf{x}$ & & $\mathrm{x}$ & & & & & $\mathrm{x}$ & $\mathrm{x}$ & $\mathrm{x}$ & $\mathrm{x}$ & $\mathrm{x}$ & & & $\mathrm{x}$ \\
\hline 156 & Dipsastraea amicorum & $\mathbf{x}$ & $\mathbf{x}$ & & $\mathrm{x}$ & $\mathrm{x}$ & $\mathrm{x}$ & $\mathrm{x}$ & & & & $\mathrm{x}$ & $\mathrm{x}$ & & $\mathrm{x}$ & $\mathrm{x}$ & & $\mathrm{x}$ & & & \\
\hline 157 & Dipsastraea camrasensis ${ }^{\mathrm{b}}$ & & & & & & & $\mathrm{x}$ & & & & & & $\mathrm{x}$ & & & & & & & \\
\hline 158 & Dipsastraea favus & $\mathbf{x}$ & $\mathbf{x}$ & $\mathbf{x}$ & $\mathbf{x}$ & $\mathbf{x}$ & $\mathbf{x}$ & $\mathbf{x}$ & & & $\mathrm{x}$ & $\mathrm{x}$ & & $\mathrm{x}$ & $\mathrm{x}$ & $\mathrm{x}$ & & $\mathrm{x}$ & $\mathrm{x}$ & & \\
\hline 159 & Dipsastraea helianthoides & $\mathbf{x}$ & $\mathbf{x}$ & $\mathbf{x}$ & $\mathbf{x}$ & $\mathbf{x}$ & & $\mathrm{x}$ & $\mathrm{x}$ & & & & & & $\mathrm{x}$ & & & & & & \\
\hline 160 & Dipsastraea lizardensis & $\mathrm{x}$ & $\mathrm{x}$ & $\mathrm{x}$ & & $\mathrm{x}$ & $\mathrm{x}$ & & $\mathrm{x}$ & & $\mathrm{x}$ & & & & $\mathrm{x}$ & & $\mathrm{x}$ & & & & \\
\hline 161 & Dipsastraea maritima & & $\mathrm{x}$ & & & & $\mathrm{x}$ & $\mathrm{x}$ & & & & & & & $\mathrm{x}$ & $\mathrm{x}$ & $\mathrm{x}$ & & & & $\mathbf{x}$ \\
\hline 162 & Dipsastraea matthaii & $\mathbf{x}$ & $\mathbf{x}$ & $\mathbf{x}$ & $\mathbf{x}$ & & $\mathrm{x}$ & & $\mathrm{x}$ & & & $\mathrm{x}$ & $\mathrm{x}$ & & & & & & & & \\
\hline 163 & Dipsastraea maxima & $\mathbf{x}$ & $\mathbf{x}$ & $\mathbf{x}$ & & $\mathrm{x}$ & & & & & & & & & $\mathrm{x}$ & $\mathrm{x}$ & & & & & \\
\hline 164 & Dipsastraea pallida & $\mathbf{x}$ & & $\mathrm{x}$ & & & $\mathrm{x}$ & $\mathrm{x}$ & & & & & & & $\mathrm{x}$ & & & & & & \\
\hline 165 & Dipsastraea rosaria & & $\mathrm{x}$ & $\mathrm{x}$ & & $\mathrm{x}$ & & $\mathrm{x}$ & & & & & & & & & & & & & \\
\hline 166 & Dipsastraea rotundata & & $\mathrm{x}$ & & & $\mathrm{x}$ & $\mathrm{x}$ & & & & & & & & $\mathrm{x}$ & & & & & & \\
\hline 167 & Dipsastraea speciosa ${ }^{\text {a }}$ & $\mathbf{x}$ & $\mathbf{x}$ & $\mathbf{x}$ & $\mathbf{x}$ & $\mathbf{x}$ & $\mathbf{x}$ & $\mathbf{x}$ & $\mathbf{x}$ & $\mathbf{x}$ & $\mathbf{x}$ & $\mathbf{x}$ & $\mathbf{x}$ & $\mathbf{x}$ & $\mathrm{x}$ & $\mathrm{x}$ & $\mathrm{x}$ & $\mathrm{x}$ & & $\mathbf{x}$ & $\mathbf{x}$ \\
\hline 168 & Dipsastraea truncatus & $\mathbf{x}$ & & $\mathrm{x}$ & & & & & $\mathrm{x}$ & & & & & & & & & $\mathrm{x}$ & $\mathrm{x}$ & & \\
\hline 169 & Dipsastraea vietnamensis & $\mathrm{x}$ & & $\mathrm{x}$ & & & & & & & & & & & & $\mathrm{x}$ & & $\mathrm{x}$ & & & \\
\hline 170 & Dipsastraea veroni & $\mathbf{x}$ & & $\mathrm{x}$ & & $\mathrm{x}$ & & $\mathrm{x}$ & & $\mathrm{x}$ & $\mathrm{x}$ & & & $\mathrm{x}$ & $\mathrm{x}$ & & $\mathrm{x}$ & & & & \\
\hline 171 & Echinopora gemmacea ${ }^{\mathrm{b}}$ & & & & & $\mathrm{x}$ & & & & & & & & & & & & & & & \\
\hline 172 & Echinopora horrida ${ }^{\mathrm{b}}$ & & & & & & & & & $\mathrm{x}$ & & & & & & & $\mathrm{x}$ & & & & \\
\hline 173 & Echinopora lamellosa & $\mathrm{x}$ & $\mathrm{x}$ & $\mathrm{x}$ & & & $\mathrm{x}$ & $\mathrm{x}$ & & $\mathrm{x}$ & $\mathrm{x}$ & & & $\mathrm{x}$ & $\mathrm{x}$ & & $\mathrm{x}$ & $\mathrm{x}$ & $\mathrm{x}$ & & \\
\hline 174 & Echinopora pacificus & $\mathbf{x}$ & & & & & $\mathrm{x}$ & & & $\mathrm{x}$ & & & & $\mathrm{x}$ & & $\mathrm{x}$ & & & $\mathrm{x}$ & & \\
\hline 175 & Favites abdita $^{\text {a }}$ & $\mathbf{x}$ & $\mathbf{x}$ & $\mathbf{x}$ & $\mathbf{x}$ & $\mathbf{x}$ & $\mathbf{x}$ & $\mathbf{x}$ & $\mathrm{x}$ & $\mathrm{x}$ & $\mathrm{x}$ & $\mathrm{x}$ & & $\mathrm{x}$ & $\mathrm{x}$ & $\mathrm{x}$ & $\mathrm{x}$ & $\mathrm{x}$ & $\mathrm{x}$ & & $\mathbf{x}$ \\
\hline 176 & Favites acuticollis & & $\mathrm{x}$ & $\mathrm{x}$ & $\mathrm{x}$ & $\mathrm{x}$ & & & & & & & & $\mathrm{x}$ & & & $\mathrm{x}$ & & & & \\
\hline 177 & Favites chinensis ${ }^{b}$ & $\mathbf{x}$ & & $\mathrm{x}$ & & & & & & & & & & $\mathrm{x}$ & & & & & & & \\
\hline 178 & Favites colemani $^{\text {b }}$ & & $\mathrm{x}$ & & & & & & & & & & & & & & & & & & \\
\hline 179 & Favites complanata & $\mathrm{x}$ & $\mathrm{x}$ & $\mathrm{x}$ & & $\mathrm{x}$ & $\mathrm{x}$ & $\mathrm{x}$ & $\mathrm{x}$ & & & & & $\mathrm{x}$ & $\mathrm{x}$ & & $\mathrm{x}$ & & $\mathrm{x}$ & & $\mathbf{x}$ \\
\hline 180 & Favites flexuosa & $\mathbf{x}$ & $\mathrm{x}$ & $\mathrm{x}$ & & & & & $\mathrm{x}$ & & & $\mathrm{x}$ & & & & $\mathrm{x}$ & & $\mathrm{x}$ & & & \\
\hline 181 & Favites halicora & $\mathbf{x}$ & $\mathbf{x}$ & $\mathbf{x}$ & & $\mathrm{x}$ & $\mathrm{x}$ & $\mathrm{x}$ & $\mathrm{x}$ & $\mathrm{x}$ & $\mathrm{x}$ & $\mathrm{x}$ & $\mathrm{x}$ & $\mathrm{x}$ & $\mathrm{x}$ & $\mathrm{x}$ & $\mathrm{x}$ & $\mathrm{x}$ & & & $\mathbf{x}$ \\
\hline 182 & Favites magnistellata & & & $\mathrm{x}$ & & $\mathrm{x}$ & & $\mathrm{x}$ & & & & & & $\mathrm{x}$ & $\mathrm{x}$ & $\mathrm{x}$ & $\mathrm{x}$ & & & & \\
\hline 183 & Favites melicerum & $\mathbf{x}$ & $\mathbf{x}$ & $\mathbf{x}$ & & $\mathrm{x}$ & $\mathrm{x}$ & & & & & & & & & & & & & & \\
\hline 184 & Favites micropentagonus & $\mathbf{x}$ & $\mathbf{x}$ & & & & & $\mathrm{x}$ & & & & & & $\mathrm{x}$ & & & & & & & \\
\hline 185 & Favites paraflexuosus & $\mathbf{x}$ & $\mathbf{x}$ & & & $\mathrm{x}$ & $\mathrm{x}$ & $\mathrm{x}$ & & & & & & & & & & & & & \\
\hline 186 & Favites pentagona & $\mathbf{x}$ & $\mathbf{x}$ & $\mathbf{x}$ & & & $\mathrm{x}$ & $\mathrm{x}$ & & & & & & & $\mathrm{x}$ & & $\mathrm{x}$ & & & & $\mathbf{x}$ \\
\hline 187 & Favites valenciennes $i^{\mathrm{b}}$ & & & & & $\mathrm{x}$ & & $\mathrm{x}$ & & & & & & & & & & $\mathrm{x}$ & & & \\
\hline 188 & Goniastrea edwardsi ${ }^{\text {a }}$ & $\mathrm{x}$ & $\mathrm{x}$ & $\mathrm{x}$ & $\mathrm{x}$ & $\mathrm{x}$ & $\mathrm{x}$ & $\mathrm{x}$ & $\mathrm{x}$ & $\mathrm{x}$ & $\mathrm{x}$ & $\mathrm{x}$ & $\mathrm{x}$ & $\mathrm{x}$ & $\mathrm{x}$ & $\mathrm{x}$ & $\mathrm{x}$ & $\mathrm{x}$ & $\mathrm{x}$ & & $\mathrm{x}$ \\
\hline 189 & Goniastrea favulus & & $\mathrm{x}$ & & $\mathrm{x}$ & $\mathrm{x}$ & & & & & & & & $\mathrm{x}$ & & & $\mathrm{x}$ & & & $\mathrm{x}$ & \\
\hline 190 & Goniastrea minuta $^{\mathrm{b}}$ & & & & & $\mathrm{x}$ & $\mathrm{x}$ & $\mathrm{x}$ & & & & & & & & & & & & & \\
\hline 191 & Goniastrea pectinata $^{\text {a }}$ & $\mathbf{x}$ & $\mathbf{x}$ & $\mathbf{x}$ & $\mathbf{x}$ & $\mathbf{x}$ & $\mathbf{x}$ & $\mathbf{x}$ & $\mathbf{x}$ & $\mathbf{x}$ & $\mathbf{x}$ & $\mathbf{x}$ & $\mathbf{x}$ & $\mathbf{x}$ & $\mathbf{x}$ & $\mathbf{x}$ & $\mathbf{x}$ & $\mathbf{x}$ & $\mathrm{x}$ & & \\
\hline 192 & Goniastrea retiformis a & $\mathbf{x}$ & $\mathbf{x}$ & $\mathbf{x}$ & $\mathbf{x}$ & $\mathbf{x}$ & $\mathbf{x}$ & $\mathbf{x}$ & $\mathbf{x}$ & $\mathbf{x}$ & $\mathbf{x}$ & $\mathbf{x}$ & & $\mathrm{x}$ & $\mathrm{x}$ & $\mathrm{x}$ & $\mathrm{x}$ & $\mathrm{x}$ & $\mathrm{x}$ & & $\mathbf{x}$ \\
\hline 193 & Goniastrea stelligera & $\mathbf{x}$ & & $\mathrm{x}$ & & $\mathrm{x}$ & $\mathrm{x}$ & & & & & & & & & & & & $\mathrm{x}$ & & \\
\hline 194 & Hydnophora exesa & $\mathbf{x}$ & $\mathbf{x}$ & $\mathbf{x}$ & $\mathrm{x}$ & $\mathrm{x}$ & $\mathrm{x}$ & $\mathrm{x}$ & & & & $\mathrm{x}$ & & $\mathrm{x}$ & $\mathrm{x}$ & & & $\mathrm{x}$ & $\mathrm{x}$ & & \\
\hline 195 & Hydnophora microconos & $\mathbf{x}$ & $\mathbf{x}$ & & & $\mathrm{x}$ & $\mathrm{x}$ & $\mathrm{x}$ & $\mathrm{x}$ & $\mathrm{x}$ & $\mathrm{x}$ & & & $\mathrm{x}$ & & & & & & & \\
\hline 196 & Hydnophora pilosa ${ }^{\mathrm{b}}$ & $\mathbf{x}$ & & & & & & & & & & & & & & & & & & & $\mathbf{x}$ \\
\hline 197 & Hydnophora rigida & $\mathbf{x}$ & & & & & $\mathrm{x}$ & & $\mathrm{x}$ & $\mathrm{x}$ & & $\mathrm{x}$ & & $\mathrm{x}$ & $\mathrm{x}$ & $\mathrm{x}$ & & $\mathrm{x}$ & & $\mathbf{x}$ & $\mathbf{x}$ \\
\hline 198 & Leptoria phrygia & $\mathbf{x}$ & $\mathbf{x}$ & $\mathbf{x}$ & $\mathbf{x}$ & $\mathbf{x}$ & $\mathbf{x}$ & $\mathbf{x}$ & $\mathrm{x}$ & & & & & $\mathrm{x}$ & & & & & $\mathrm{x}$ & & \\
\hline 199 & Merulina ampliata & $\mathbf{x}$ & $\mathbf{x}$ & $\mathbf{x}$ & $\mathbf{x}$ & $\mathbf{x}$ & $\mathbf{x}$ & $\mathbf{x}$ & $\mathbf{x}$ & & & & & $\mathrm{x}$ & $\mathrm{x}$ & & $\mathrm{x}$ & & $\mathrm{x}$ & & \\
\hline 200 & Merulina scabricula & $\mathbf{x}$ & $\mathbf{x}$ & $\mathbf{x}$ & & $\mathrm{x}$ & $\mathrm{x}$ & $\mathrm{x}$ & & $\mathrm{x}$ & & $\mathrm{x}$ & & $\mathrm{x}$ & $\mathrm{x}$ & & & & & & $\mathbf{x}$ \\
\hline 201 & Oulophyllia bennettae ${ }^{\text {b }}$ & & & $\mathrm{x}$ & & & & & & & & & & & & & & $\mathrm{x}$ & & & \\
\hline 202 & Oulophyllia crispa & $\mathbf{x}$ & $\mathbf{x}$ & $\mathbf{x}$ & & $\mathrm{x}$ & $\mathrm{x}$ & & $\mathrm{x}$ & & & & & & & & & $\mathrm{x}$ & $\mathrm{x}$ & & $\mathbf{x}$ \\
\hline 203 & Paragoniastrea australensis & $\mathbf{x}$ & & & & $\mathrm{x}$ & & & & & & & & $\mathrm{x}$ & $\mathrm{x}$ & & & & & & \\
\hline 204 & Paragoniastrea russelli & $\mathbf{x}$ & $\mathbf{x}$ & $\mathbf{x}$ & & $\mathrm{x}$ & $\mathrm{x}$ & & & & & & & & $\mathrm{x}$ & & & & & & \\
\hline 205 & Pectinia alcicornis ${ }^{\mathrm{b}}$ & & $\mathrm{x}$ & & & & & & & & & & & & $\mathrm{x}$ & & & & & & \\
\hline 206 & Pectinia lactuca ${ }^{\mathrm{b}}$ & & & $\mathrm{x}$ & & $\mathrm{x}$ & $\mathrm{x}$ & & & & & & & & & & & & & & \\
\hline
\end{tabular}




\begin{tabular}{|c|c|c|c|c|c|c|c|c|c|c|c|c|c|c|c|c|c|c|c|c|c|}
\hline \multirow{2}{*}{ No. } & \multirow{2}{*}{ Scleractinian coral species } & \multicolumn{6}{|c|}{ East coast zone (TE) } & \multicolumn{6}{|c|}{ West coast zone (TW) } & \multicolumn{8}{|c|}{ Isolated zone (TI) } \\
\hline & & 1 & 2 & 3 & 4 & 5 & 6 & 1 & 2 & 3 & 4 & 5 & 6 & 1 & 2 & 3 & 4 & 5 & 6 & 7 & 8 \\
\hline 207 & Pectinia paeonia $^{\mathrm{b}}$ & & & & & & & & & & & & & & $\mathrm{x}$ & & & & & & \\
\hline 208 & Platygyra acuta & $\mathbf{x}$ & $\mathbf{x}$ & $\mathbf{x}$ & & $\mathrm{x}$ & $\mathrm{x}$ & $\mathrm{x}$ & & & $\mathrm{x}$ & & & $\mathrm{x}$ & $\mathrm{x}$ & & $\mathrm{x}$ & $\mathrm{x}$ & & & $\mathbf{x}$ \\
\hline 209 & Platygyra carnosus & $\mathbf{x}$ & $\mathbf{x}$ & $\mathbf{x}$ & & & $\mathrm{x}$ & & $\mathrm{x}$ & & $\mathrm{x}$ & & & & & & & $\mathrm{x}$ & & & \\
\hline 210 & Platygyra contorta & & $\mathrm{x}$ & & & & $\mathrm{x}$ & & & & & & & & $\mathrm{x}$ & & $\mathrm{x}$ & $\mathrm{x}$ & & & \\
\hline 211 & Platygyra crosslandi & $\mathbf{x}$ & & & & & & $\mathrm{x}$ & & & $\mathrm{x}$ & & & $\mathrm{x}$ & $\mathrm{x}$ & $\mathrm{x}$ & $\mathrm{x}$ & & & & \\
\hline 212 & Platygyra daedalea & $\mathbf{x}$ & $\mathbf{x}$ & $\mathbf{x}$ & $\mathbf{x}$ & $\mathbf{x}$ & $\mathbf{x}$ & $\mathbf{x}$ & $\mathbf{x}$ & $\mathbf{x}$ & $\mathbf{x}$ & & & $\mathrm{x}$ & $\mathrm{x}$ & & $\mathrm{x}$ & $\mathrm{x}$ & $\mathrm{x}$ & & $\mathbf{x}$ \\
\hline 213 & Platygyra lamellina & $\mathbf{x}$ & $\mathbf{x}$ & $\mathbf{x}$ & & $\mathrm{x}$ & $\mathrm{x}$ & $\mathrm{x}$ & $\mathrm{x}$ & $\mathrm{x}$ & $\mathrm{x}$ & & & $\mathrm{x}$ & $\mathrm{x}$ & $\mathrm{x}$ & $\mathrm{x}$ & $\mathrm{x}$ & $\mathrm{x}$ & $\mathrm{x}$ & \\
\hline 214 & Platygyra pini ${ }^{\text {a }}$ & $\mathbf{x}$ & $\mathbf{x}$ & $\mathbf{x}$ & $\mathbf{x}$ & $\mathbf{x}$ & $\mathbf{x}$ & $\mathbf{x}$ & $\mathbf{x}$ & $\mathbf{x}$ & $\mathbf{x}$ & $\mathbf{x}$ & & $\mathrm{x}$ & $\mathrm{x}$ & $\mathrm{x}$ & $\mathrm{x}$ & $\mathrm{x}$ & $\mathrm{x}$ & & $\mathbf{x}$ \\
\hline 215 & Platygyra ryukyuensis & $\mathbf{x}$ & $\mathbf{x}$ & $\mathbf{x}$ & & $\mathrm{x}$ & $\mathrm{x}$ & $\mathrm{x}$ & $\mathrm{x}$ & $\mathrm{x}$ & & & & $\mathrm{x}$ & & $\mathrm{x}$ & $\mathrm{x}$ & & & & \\
\hline 216 & Platygyra sinensis a & $\mathbf{x}$ & $\mathbf{x}$ & $\mathbf{x}$ & $\mathbf{x}$ & $\mathbf{x}$ & $\mathbf{x}$ & $\mathbf{x}$ & $\mathbf{x}$ & $\mathbf{x}$ & $\mathbf{x}$ & & & $\mathrm{x}$ & $\mathrm{x}$ & $\mathrm{x}$ & $\mathrm{x}$ & $\mathrm{x}$ & $\mathrm{x}$ & & $\mathbf{x}$ \\
\hline 217 & Platygyra verweyi ${ }^{\mathrm{a}}$ & $\mathbf{x}$ & $\mathbf{x}$ & $\mathbf{x}$ & $\mathbf{x}$ & $\mathbf{x}$ & $\mathbf{x}$ & $\mathbf{x}$ & $\mathbf{x}$ & & $\mathrm{x}$ & $\mathrm{x}$ & $\mathrm{x}$ & $\mathrm{x}$ & $\mathbf{x}$ & $\mathbf{x}$ & $\mathbf{x}$ & $\mathbf{x}$ & $\mathbf{x}$ & $\mathbf{x}$ & $\mathbf{x}$ \\
\hline 218 & Platygyra yaeyamaensis ${ }^{\mathrm{b}}$ & & & & & $\mathrm{x}$ & $\mathrm{x}$ & & & & & & & & & & & & & & \\
\hline 219 & Scapophyllia cylindrica ${ }^{\mathrm{b}}$ & $\mathbf{x}$ & & & & & & & & & & & & & & & & & & & \\
\hline \multirow[t]{2}{*}{220} & Trachyphyllia geoffroyi $^{\mathrm{b}}$ & & & & & & $\mathrm{x}$ & & & & & & & & & & & & & & \\
\hline & \multicolumn{21}{|l|}{ Pocilloporidae } \\
\hline 221 & Pocillopora acuta & & $\mathrm{x}$ & & & & $\mathrm{x}$ & & & & & & $\mathrm{x}$ & & & $\mathrm{x}$ & $\mathrm{x}$ & $\mathrm{x}$ & $\mathrm{x}$ & $\mathrm{x}$ & $\mathbf{x}$ \\
\hline 222 & Pocillopora damicornis ${ }^{\text {a }}$ & $\mathbf{x}$ & $\mathbf{x}$ & $\mathbf{x}$ & $\mathbf{x}$ & $\mathbf{x}$ & $\mathbf{x}$ & $\mathbf{x}$ & $\mathbf{x}$ & $\mathbf{x}$ & $\mathbf{x}$ & $\mathbf{x}$ & $\mathbf{x}$ & $\mathbf{x}$ & $\mathbf{x}$ & $\mathbf{x}$ & $\mathbf{x}$ & $\mathbf{x}$ & $\mathbf{x}$ & $\mathbf{x}$ & $\mathbf{x}$ \\
\hline 223 & Pocillopora meandrina ${ }^{\mathrm{b}}$ & & & & & $\mathrm{x}$ & & & & & & & & & & & & $\mathrm{x}$ & $\mathrm{x}$ & & \\
\hline 224 & Pocillopora verrucosa & $\mathbf{x}$ & $\mathbf{x}$ & $\mathbf{x}$ & $\mathbf{x}$ & & $\mathrm{x}$ & & $\mathrm{x}$ & $\mathrm{x}$ & & & & & & & & $\mathrm{x}$ & $\mathrm{x}$ & $\mathrm{x}$ & \\
\hline 225 & Stylophora pistillata ${ }^{\mathrm{b}}$ & & & & & & & & & $\mathrm{x}$ & & $\mathrm{x}$ & & & & & & & & & \\
\hline \multirow[t]{2}{*}{226} & Stylophora subseriata ${ }^{\mathrm{b}}$ & & & & & & & & & $\mathrm{x}$ & & $\mathrm{x}$ & & & & & & & & & \\
\hline & \multicolumn{21}{|l|}{ Poritidae } \\
\hline 227 & Goniopora columna & & $\mathrm{x}$ & $\mathrm{x}$ & & $\mathrm{x}$ & $\mathrm{x}$ & & & $\mathrm{x}$ & & & & $\mathrm{x}$ & $\mathrm{x}$ & $\mathrm{x}$ & & & & & \\
\hline 228 & Goniopora djiboutiensis $^{\mathrm{b}}$ & & & & & & & & & & & $\mathrm{x}$ & & & & & & & & & \\
\hline 229 & Goniopora lobata & & $\mathrm{x}$ & $\mathrm{x}$ & & & & & & & & & & & & $\mathrm{x}$ & & & & $\mathbf{x}$ & $\mathbf{x}$ \\
\hline 230 & Porites annae & $\mathbf{x}$ & & & & $\mathrm{x}$ & & $\mathrm{x}$ & & & & & & & $\mathrm{x}$ & & $\mathrm{x}$ & $\mathrm{x}$ & & & \\
\hline 231 & Porites australiensis & $\mathbf{x}$ & & $\mathrm{x}$ & & $\mathrm{x}$ & & $\mathrm{x}$ & $\mathrm{x}$ & $\mathrm{x}$ & $\mathrm{x}$ & $\mathrm{x}$ & & $\mathrm{x}$ & $\mathrm{x}$ & & $\mathrm{x}$ & & $\mathrm{x}$ & & \\
\hline 232 & Porites cylindrica & $\mathbf{x}$ & & $\mathrm{x}$ & & $\mathrm{x}$ & $\mathrm{x}$ & $\mathrm{x}$ & $\mathrm{x}$ & $\mathrm{x}$ & $\mathrm{x}$ & $\mathrm{x}$ & & $\mathrm{x}$ & $\mathrm{x}$ & $\mathrm{x}$ & $\mathrm{x}$ & $\mathrm{x}$ & & & \\
\hline 233 & Porites densa ${ }^{\mathrm{b}}$ & & & $\mathrm{x}$ & & $\mathrm{x}$ & $\mathrm{x}$ & & & & & & & & & & & & & & \\
\hline 234 & Porites horizontalata & $\mathbf{x}$ & & & $\mathrm{x}$ & $\mathrm{x}$ & $\mathrm{x}$ & $\mathrm{x}$ & $\mathrm{x}$ & $\mathrm{x}$ & & & & $\mathrm{x}$ & $\mathrm{x}$ & & $\mathrm{x}$ & & & & \\
\hline 235 & Porites lichen & $\mathbf{x}$ & & $\mathrm{x}$ & & $\mathrm{x}$ & $\mathrm{x}$ & $\mathrm{x}$ & $\mathrm{x}$ & $\mathrm{x}$ & & & & & & & & $\mathrm{x}$ & & & \\
\hline 236 & Porites lobata $^{\text {a }}$ & $\mathbf{x}$ & $\mathbf{x}$ & $\mathbf{x}$ & $\mathbf{x}$ & $\mathbf{x}$ & $\mathbf{x}$ & $\mathbf{x}$ & $\mathbf{x}$ & $\mathbf{x}$ & $\mathbf{x}$ & $\mathbf{x}$ & & $\mathrm{x}$ & $\mathrm{x}$ & $\mathrm{x}$ & $\mathrm{x}$ & $\mathrm{x}$ & $\mathrm{x}$ & & $\mathbf{x}$ \\
\hline 237 & Porites lutea ${ }^{\text {a }}$ & $\mathbf{x}$ & $\mathbf{x}$ & $\mathbf{x}$ & $\mathbf{x}$ & $\mathbf{x}$ & $\mathbf{x}$ & $\mathbf{x}$ & $\mathbf{x}$ & $\mathbf{x}$ & $\mathbf{x}$ & $\mathrm{x}$ & & $\mathbf{x}$ & $\mathbf{x}$ & $\mathbf{x}$ & $\mathbf{x}$ & $\mathbf{x}$ & $\mathbf{x}$ & $\mathbf{x}$ & $\mathbf{x}$ \\
\hline 238 & Porites mayeri ${ }^{\mathrm{b}}$ & & & & & & & & & & & & & $\mathrm{x}$ & & & & & & & \\
\hline 239 & Porites monticulosa & $\mathbf{x}$ & & & & $\mathrm{x}$ & & $\mathrm{x}$ & & & & & & $\mathrm{x}$ & $\mathrm{x}$ & & $\mathrm{x}$ & & & & \\
\hline 240 & Porites murrayensis ${ }^{\mathrm{b}}$ & & & & & $\mathrm{x}$ & & $\mathrm{x}$ & & & & & & & $\mathrm{x}$ & & & & & & \\
\hline 241 & Porites nigrescens ${ }^{\mathrm{b}}$ & & & & & & & & & $\mathrm{x}$ & & & & & & & $\mathrm{x}$ & & & & \\
\hline 242 & Porites rus ${ }^{\text {a }}$ & $\mathbf{x}$ & $\mathbf{x}$ & $\mathbf{x}$ & $\mathbf{x}$ & $\mathbf{x}$ & $\mathbf{x}$ & $\mathbf{x}$ & $\mathbf{x}$ & $\mathbf{x}$ & $\mathbf{x}$ & $\mathbf{x}$ & $\mathbf{x}$ & $\mathbf{x}$ & $\mathbf{x}$ & & $\mathbf{x}$ & $\mathbf{x}$ & $\mathbf{x}$ & $\mathbf{x}$ & $\mathbf{x}$ \\
\hline \multirow[t]{2}{*}{243} & Porites solida & $\mathbf{x}$ & $\mathbf{x}$ & $\mathbf{x}$ & $\mathbf{x}$ & $\mathbf{x}$ & & $\mathrm{x}$ & $\mathrm{x}$ & & & & & $\mathrm{x}$ & $\mathrm{x}$ & & & $\mathrm{x}$ & & $\mathrm{x}$ & $\mathrm{x}$ \\
\hline & Psammocoridae & & & & & & & & & & & & & & & & & & & & \\
\hline 244 & Psammocora contigua & & & $\mathrm{x}$ & & $\mathrm{x}$ & $\mathrm{x}$ & $\mathrm{x}$ & $\mathrm{x}$ & $\mathrm{x}$ & $\mathrm{x}$ & & & $\mathrm{x}$ & $\mathrm{x}$ & $\mathrm{x}$ & $\mathrm{x}$ & $\mathrm{x}$ & & & \\
\hline 245 & Psammocora digitata & $\mathbf{x}$ & & $\mathrm{x}$ & $\mathrm{x}$ & $\mathrm{x}$ & $\mathrm{x}$ & $\mathrm{x}$ & $\mathrm{x}$ & & & & & $\mathrm{x}$ & $\mathrm{x}$ & & & & $\mathrm{x}$ & & $\mathbf{x}$ \\
\hline 246 & Psammocora haimiana ${ }^{\mathrm{b}}$ & & & & & & & & & & & & & & & $\mathrm{x}$ & & & $\mathrm{x}$ & & \\
\hline 247 & Psammocora profundacella ${ }^{\mathrm{b}}$ & & & $\mathrm{x}$ & & & & & & & & & & & & & & & & & \\
\hline & Siderastreidae & & & & & & & & & & & & & & & & & & & & \\
\hline 248 & Pseudosiderastrea tayam $i^{\text {b }}$ & & & $\mathrm{x}$ & & & & & & & & & & & & & & & & & \\
\hline & Scleractinia Incertae sedis & & & & & & & & & & & & & & & & & & & & \\
\hline 249 & Leptastrea pruinosa & & & & & & & $\mathrm{x}$ & $\mathrm{x}$ & $\mathrm{x}$ & & $\mathrm{x}$ & & $\mathrm{x}$ & & & & $\mathrm{x}$ & & & \\
\hline 250 & Leptastrea purpurea & $\mathrm{x}$ & $\mathrm{x}$ & & & $\mathrm{x}$ & & $\mathrm{x}$ & $\mathrm{x}$ & $\mathrm{x}$ & $\mathrm{x}$ & & & $\mathrm{x}$ & $\mathrm{x}$ & $\mathrm{x}$ & $\mathrm{x}$ & $\mathrm{x}$ & & & $\mathbf{x}$ \\
\hline 251 & Leptastrea transversa & $\mathbf{x}$ & & $\mathrm{x}$ & & & & $\mathrm{x}$ & & $\mathrm{x}$ & & & & $\mathrm{x}$ & & & $\mathrm{x}$ & & & & \\
\hline 252 & Physogyra lichtenstein ${ }^{\mathrm{b}}$ & & & & & & & & & $\mathrm{x}$ & & & & & & $\mathrm{x}$ & & & $\mathrm{x}$ & & \\
\hline 253 & Plerogyra sinuosa & & & & $\mathrm{x}$ & $\mathrm{x}$ & $\mathrm{x}$ & $\mathrm{x}$ & $\mathrm{x}$ & $\mathrm{x}$ & $\mathrm{x}$ & & $\mathrm{x}$ & $\mathrm{x}$ & & $\mathrm{x}$ & $\mathrm{x}$ & $\mathrm{x}$ & $\mathrm{x}$ & $\mathrm{x}$ & $\mathrm{x}$ \\
\hline 254 & Plesiastrea versipora & & & $\mathrm{x}$ & & $\mathrm{x}$ & & $\mathrm{x}$ & & & & & & & & & & $\mathrm{x}$ & $\mathrm{x}$ & & $\mathrm{x}$ \\
\hline & $\begin{array}{l}254 \text { species, } 61 \text { genera and } \\
14 \text { families }\end{array}$ & 138 & 110 & 129 & 70 & 155 & 123 & 122 & 87 & 87 & 65 & 62 & 35 & 111 & 112 & 91 & 81 & 92 & 56 & 33 & 62 \\
\hline
\end{tabular}


Supplementary Table 2. List of scleractinian coral species in TIMP. Symbol x indicates species occurrence. Species that were not previously recorded are highlighted. Previous records were obtained from Harborne et al. (2000), Affendi et al. (2005) and Affendi et al. (2007) and updated according to the World Register of Marine Species (WoRMS). The abundance and conservation status for each species were referred based on the websites of Corals of the World (COTW) and IUCN Red List of Threatened Species.

\begin{tabular}{|c|c|c|c|c|c|c|c|}
\hline No. & Scleractinian hard coral species & $\begin{array}{l}\text { Harborne } \\
\text { et al. } 2000\end{array}$ & $\begin{array}{l}\text { Affendi et } \\
\text { al. } 2005\end{array}$ & $\begin{array}{l}\text { Affendi et } \\
\text { al. } 2007\end{array}$ & $\begin{array}{l}\text { Present } \\
\text { Record }\end{array}$ & $\begin{array}{c}\text { Abundance } \\
\text { (COTW) }\end{array}$ & $\begin{array}{l}\text { IUCN Red } \\
\text { List }\end{array}$ \\
\hline & Acroporidae Verrill, 1902 & & & & & & \\
\hline 1 & Acropora abrolhosensis Veron, 1985 & & $\mathrm{x}$ & $\mathrm{x}$ & $\mathrm{x}$ & $\mathrm{C}$ & VU \\
\hline 2 & Acropora aculeus (Dana, 1846) & & $\mathrm{x}$ & & & $\mathbf{C}$ & $\mathbf{V U}$ \\
\hline 3 & Acropora anthocersis (Brook, 1893) & & & $\mathbf{x}$ & $\mathbf{x}$ & $\mathbf{C}$ & VU \\
\hline 4 & Acropora appressa (Ehrenberg, 1834) & & & $\mathrm{x}$ & & UC & NT \\
\hline 5 & Acropora aspera (Dana, 1846) & $\mathrm{x}$ & $\mathrm{x}$ & $\mathrm{x}$ & & $\mathbf{C}$ & $\mathbf{V U}$ \\
\hline 6 & Acropora austera (Dana, 1846) & $\mathrm{x}$ & $\mathrm{x}$ & $\mathbf{x}$ & $\mathbf{x}$ & $\mathbf{U C}$ & NT \\
\hline 7 & Acropora awi allace \& Wolstenholme, 1998 & & $\mathrm{x}$ & & & $\mathbf{C}$ & VU \\
\hline 8 & Acropora carduus (Dana, 1846) & & & & $\mathrm{x}$ & $\mathrm{C}$ & NT \\
\hline 9 & Acropora cerealis (Dana, 1846) & & $\mathbf{x}$ & $\mathbf{x}$ & $\mathbf{x}$ & $\mathbf{C}$ & LC \\
\hline 10 & Acropora clathrata (Brook, 1891) & & & $\mathrm{x}$ & $\mathrm{x}$ & $\mathrm{C}$ & LC \\
\hline 11 & Acropora cytherea (Dana, 1846) & $\mathbf{x}$ & $\mathbf{x}$ & $\mathbf{x}$ & $\mathbf{x}$ & $\mathbf{C}$ & LC \\
\hline 12 & Acropora dendrum (Bassett-Smith, 1890) & & & $\mathrm{x}$ & & $\mathbf{R}$ & $\mathbf{V U}$ \\
\hline 13 & Acropora digitifera (Dana, 1846) & $\mathbf{x}$ & $\mathbf{x}$ & $\mathbf{x}$ & $\mathbf{x}$ & $\mathbf{C}$ & NT \\
\hline 14 & Acropora divaricata (Dana, 1846) & & & & $\mathbf{x}$ & $\mathbf{C}$ & NT \\
\hline 15 & Acropora donei Veron \& Wallace, 1984 & & $\mathbf{x}$ & $\mathbf{x}$ & $\mathbf{x}$ & UC & $\mathbf{V U}$ \\
\hline 16 & Acropora elseyi (Brook, 1892) & & $\mathrm{x}$ & $\mathrm{x}$ & & $\mathrm{C}$ & LC \\
\hline 17 & Acropora florida (Dana, 1846) & $\mathbf{x}$ & $\mathbf{x}$ & $\mathbf{x}$ & $\mathbf{x}$ & C & NT \\
\hline 18 & Acropora gemmifera (Brook, 1892) & $\mathrm{x}$ & $\mathrm{x}$ & & $\mathrm{x}$ & $\mathrm{C}$ & LC \\
\hline 19 & Acropora grandis (Brook, 1892) & & $\mathbf{x}$ & $\mathbf{x}$ & $\mathbf{x}$ & $\mathbf{C}$ & LC \\
\hline 20 & Acropora hemprichii (Ehrenberg, 1834) & & & $\mathrm{x}$ & & C & $\mathbf{V U}$ \\
\hline 21 & Acropora hoeksemai Wallace, 1997 & & & $\mathbf{x}$ & $\mathbf{x}$ & $\mathrm{C}$ & $\mathbf{V U}$ \\
\hline 22 & Acropora horrida (Dana, 1846) & $\mathbf{x}$ & $\mathbf{x}$ & $\mathbf{x}$ & $\mathbf{x}$ & UC & $\mathbf{V U}$ \\
\hline 23 & Acropora humilis (Dana, 1846) & $\mathbf{x}$ & $\mathbf{x}$ & $\mathbf{x}$ & $\mathbf{x}$ & $\mathbf{C}$ & NT \\
\hline 24 & Acropora hyacinthus (Dana, 1846) & $\mathrm{x}$ & $\mathrm{x}$ & $\mathrm{x}$ & $\mathrm{x}$ & $\mathbf{C}$ & NT \\
\hline 25 & Acropora indonesia Wallace, 1997* & & & & $\mathbf{x}$ & $\mathbf{C}$ & $\mathbf{V U}$ \\
\hline 26 & Acropora insignis Nemenzo, 1967 & & & & $\mathbf{x}$ & UC & DD \\
\hline 27 & Acropora intermedia (Brook, 1891) & $\mathrm{x}$ & $\mathbf{x}$ & $\mathbf{x}$ & $\mathbf{x}$ & $\mathbf{C}$ & - \\
\hline 28 & Acropora kirstyae Veron \& Wallace, 1984 & & $\mathrm{x}$ & & & UC & VU \\
\hline 29 & Acropora latistella (Brook, 1892) & $\mathrm{x}$ & $\mathbf{x}$ & $\mathbf{x}$ & $\mathbf{x}$ & $\mathbf{C}$ & LC \\
\hline 30 & Acropora listeri (Brook, 1893) & & $\mathrm{x}$ & & & $\mathbf{U C}$ & $\mathbf{V U}$ \\
\hline 31 & Acropora loripes (Brook, 1892) & $\mathrm{x}$ & $\mathrm{x}$ & $\mathbf{x}$ & $\mathbf{x}$ & $\mathbf{C}$ & NT \\
\hline 32 & Acropora lutkeni Crossland, 1952 & & $\mathrm{x}$ & & & $\mathbf{U C}$ & NT \\
\hline 33 & Acropora microclados (Ehrenberg, 1834) & & $\mathrm{x}$ & $\mathrm{x}$ & & UC & VU \\
\hline 34 & Acropora microphthalma (Verrill, 1869) & $\mathbf{x}$ & $\mathbf{x}$ & $\mathbf{x}$ & $\mathbf{x}$ & $\mathbf{C}$ & LC \\
\hline 35 & Acropora millepora (Ehrenberg, 1834) & $\mathrm{x}$ & $\mathrm{x}$ & $\mathbf{x}$ & $\mathbf{x}$ & $\mathbf{C}$ & NT \\
\hline 36 & Acropora monticulosa (Brüggemman, 1879) & $\mathrm{x}$ & & & $\mathbf{x}$ & $\mathbf{U C}$ & NT \\
\hline 37 & Acropora muricata (Linnaeus, 1758) & $\mathrm{x}$ & $\mathrm{x}$ & $\mathbf{x}$ & $\mathbf{x}$ & $\mathbf{C}$ & - \\
\hline 38 & Acropora nana (Studer, 1878) & & & $\mathrm{x}$ & & $\mathbf{C}$ & NT \\
\hline 39 & Acropora nasuta (Dana, 1846) & $\mathrm{x}$ & $\mathrm{x}$ & $\mathbf{x}$ & $\mathbf{x}$ & $\mathbf{C}$ & NT \\
\hline 40 & Acropora papillare Latypov, 1992 & & & $\mathrm{x}$ & & UC & $\mathbf{V U}$ \\
\hline 41 & Acropora plana Nemenzo, 1967* & & & & $\mathrm{x}$ & UC & DD \\
\hline 42 & Acropora pruinosa (Brook, 1893) & & & $\mathrm{x}$ & & UC & DD \\
\hline 43 & Acropora pulchra (Brook, 1891) & & & $\mathrm{x}$ & & UC & $\mathbf{L C}$ \\
\hline 44 & Acropora retusa (Dana, 1846) & & $\mathrm{x}$ & & & $\mathrm{UC}$ & $\mathbf{V U}$ \\
\hline 45 & Acropora robusta (Dana, 1846) & $\mathbf{x}$ & $\mathbf{x}$ & $\mathbf{x}$ & $\mathbf{x}$ & $\mathbf{C}$ & LC \\
\hline 46 & Acropora samoensis (Brook, 1891) & $\mathrm{x}$ & $\mathrm{x}$ & $\mathrm{x}$ & & UC & LC \\
\hline 47 & Acropora secale (Studer, 1878) & $\mathbf{x}$ & $\mathbf{x}$ & $\mathbf{x}$ & $\mathbf{x}$ & $\mathbf{C}$ & NT \\
\hline 48 & Acropora selago (Studer, 1878) & $\mathrm{x}$ & $\mathrm{x}$ & $\mathbf{x}$ & $\mathbf{x}$ & $\mathbf{C}$ & NT \\
\hline
\end{tabular}




\begin{tabular}{|c|c|c|c|c|c|c|c|}
\hline No. & Scleractinian hard coral species & $\begin{array}{l}\text { Harborne } \\
\text { et al. } 2000\end{array}$ & $\begin{array}{l}\text { Affendi et } \\
\text { al. } 2005\end{array}$ & $\begin{array}{c}\text { Affendi et } \\
\text { al. } 2007\end{array}$ & $\begin{array}{l}\text { Present } \\
\text { Record }\end{array}$ & $\begin{array}{c}\text { Abundance } \\
\text { (COTW) }\end{array}$ & $\begin{array}{l}\text { IUCN Red } \\
\text { List }\end{array}$ \\
\hline 49 & Acropora solitaryensis Veron \& Wallace, 1984 & $\mathbf{x}$ & $\mathbf{x}$ & $\mathbf{x}$ & $\mathbf{x}$ & $\mathbf{R}$ & VU \\
\hline 50 & Acropora spicifera (Dana, 1846) & & & & $\mathbf{x}$ & UC & VU \\
\hline 51 & Acropora tenuis (Dana, 1846) & $\mathbf{x}$ & $\mathbf{x}$ & $\mathbf{x}$ & $\mathbf{x}$ & $\mathbf{C}$ & NT \\
\hline 52 & Acropora valida (Dana, 1846) & $\mathrm{x}$ & & $\mathrm{x}$ & & $\mathbf{C}$ & $\mathbf{L C}$ \\
\hline 53 & Acropora valenciennesi (Milne Edwards \& Haime, 1860) & & $\mathrm{x}$ & & $\mathbf{x}$ & $\mathbf{C}$ & LC \\
\hline 54 & Acropora vaughani Wells, 1954 & & $\mathrm{x}$ & $\mathrm{x}$ & & $\mathbf{U C}$ & $\mathbf{V U}$ \\
\hline 55 & Acropora yongei Veron \& Wallace, 1984 & & $\mathrm{x}$ & & & $\mathbf{C}$ & $\mathbf{L C}$ \\
\hline 56 & Alveopora minuta Veron, 2000 & & $\mathrm{x}$ & & & $\mathbf{R}$ & EN \\
\hline 57 & Alveopora spongiosa Dana, 1846 & & & $\mathbf{x}$ & $\mathbf{x}$ & UC & NT \\
\hline 58 & Anacropora matthai Pillai, 1973 & $\mathrm{x}$ & & & $\mathbf{x}$ & $\mathbf{R}$ & VU \\
\hline 59 & Anacropora forbesi Ridley, 1884 & & & & $\mathrm{x}$ & UC & LC \\
\hline 60 & Anacropora puertogalerae Nemenzo, 1964* & & & & $\mathbf{x}$ & UC & VU \\
\hline 61 & Anacropora reticulata Veron \& Wallace, 1984 & & $\mathrm{x}$ & & & $\mathbf{R}$ & VU \\
\hline 62 & Astreopora gracilis Bernard, 1896 & & $\mathrm{x}$ & $\mathbf{x}$ & $\mathbf{x}$ & $\mathbf{C}$ & $\mathbf{L C}$ \\
\hline 63 & Astreopora listeri Bernard, 1896 & & $\mathrm{x}$ & & & UC & LC \\
\hline 64 & Astreopora myriophthalma (Lamarck, 1816) & $\mathrm{x}$ & $\mathrm{x}$ & $\mathbf{x}$ & $\mathbf{x}$ & $\mathbf{C}$ & $\mathbf{L C}$ \\
\hline 65 & Astreopora ocellata Bernard, 1896 & $\mathbf{x}$ & $\mathbf{x}$ & $\mathbf{x}$ & $\mathbf{x}$ & $\mathbf{R}$ & LC \\
\hline 66 & Isopora bruggemanni (Brook, 1893) & $\mathbf{x}$ & $\mathbf{x}$ & $\mathbf{x}$ & $\mathbf{x}$ & $\mathbf{C}$ & VU \\
\hline 67 & Isopora cuneata (Dana, 1846) & & & & $\mathbf{x}$ & $\mathbf{C}$ & VU \\
\hline 68 & Isopora palifera (Lamarck, 1816) & $\mathrm{x}$ & & & $\mathbf{x}$ & UC & NT \\
\hline 69 & Isopora togianensis (Wallace, 1997) & & & $\mathrm{x}$ & & $\mathbf{C}$ & EN \\
\hline 70 & Montipora aequituberculata Bernard, 1897 & $\mathrm{x}$ & & $\mathrm{x}$ & $\mathrm{x}$ & $\mathbf{C}$ & $\mathbf{L C}$ \\
\hline 71 & Montipora altasepta Nemenzo, 1967 & $\mathrm{x}$ & & & $\mathbf{x}$ & $\mathrm{C}$ & VU \\
\hline 72 & Montipora calcarea Bernard, 1897 & & & $\mathrm{x}$ & & - & VU \\
\hline 73 & Montipora caliculata (Dana, 1846) & & & $\mathrm{x}$ & & $\mathbf{U C}$ & VU \\
\hline 74 & Montipora capricornis Veron, 1985 & & & $\mathrm{x}$ & & $\mathbf{C}$ & VU \\
\hline 75 & Montipora cebuensis Nemenzo, 1976 & & & & $\mathbf{x}$ & UC & VU \\
\hline 76 & Montipora cocosensis Vaughan, 1918 & & & $\mathrm{x}$ & & - & VU \\
\hline 77 & Montipora confusa Nemenzo, 1967 & $\mathbf{x}$ & $\mathbf{x}$ & $\mathbf{x}$ & $\mathbf{x}$ & $\mathbf{U C}$ & NT \\
\hline 78 & Montipora crassituberculata Bernard, 1897 & & $\mathbf{x}$ & $\mathbf{x}$ & $\mathbf{x}$ & UC & VU \\
\hline 79 & Montipora danae (Milne Edwards \& Haime, 1851) & & $\mathbf{x}$ & $\mathbf{x}$ & $\mathbf{x}$ & $\mathbf{C}$ & $\mathbf{L C}$ \\
\hline 80 & Montipora delicatula Veron, 2000 & & $\mathbf{x}$ & $\mathbf{x}$ & $\mathbf{x}$ & UC & $\mathbf{V U}$ \\
\hline 81 & Montipora digitata (Dana, 1846) & & $\mathrm{x}$ & $\mathrm{x}$ & & $\mathbf{C}$ & $\mathbf{L C}$ \\
\hline 82 & Montipora effusa Dana, 1846 & & & $\mathrm{x}$ & & UC & NT \\
\hline 83 & Montipora efflorescens Bernard, 1897 * & & & & $\mathbf{x}$ & $\mathbf{C}$ & NT \\
\hline 84 & Montipora florida Nemenzo, 1967 & & $\mathrm{x}$ & & & $\mathrm{C}$ & VU \\
\hline 85 & Montipora foliosa (Pallas, 1766) & $\mathbf{x}$ & $\mathbf{x}$ & $\mathbf{x}$ & $\mathbf{x}$ & $\mathbf{C}$ & NT \\
\hline 86 & Montipora foveolata (Dana, 1846) & & & $\mathrm{x}$ & & UC & NT \\
\hline 87 & Montipora friabilis Bernard, 1897 & & & $\mathbf{x}$ & $\mathbf{x}$ & UC & $\mathbf{V U}$ \\
\hline 88 & Montipora gaimardi Bernard, 1897 & $\mathrm{x}$ & & & & $\mathbf{C}$ & VU \\
\hline 89 & Montipora grisea Bernard, 1897 & & & & $\mathrm{x}$ & $\mathrm{C}$ & LC \\
\hline 90 & Montipora hirsuta Nemenzo, 1967 & & & $\mathrm{x}$ & & - & NT \\
\hline 91 & Montipora hispida (Dana, 1846) & $\mathrm{x}$ & $\mathrm{x}$ & $\mathrm{x}$ & $\mathrm{x}$ & $\mathrm{UC}$ & $\mathrm{LC}$ \\
\hline 92 & Montipora informis Bernard, 1897 & $\mathrm{x}$ & & & $\mathbf{x}$ & $\mathbf{C}$ & $\mathbf{L C}$ \\
\hline 93 & Montipora malampaya Nemenzo, 1967 & $\mathrm{x}$ & & & & $\mathbf{C}$ & VU \\
\hline 94 & Montipora meandrina (Ehrenberg, 1834) & & $\mathrm{x}$ & & & UC & VU \\
\hline 95 & Montipora millepora Crossland, 1952 & & $\mathbf{x}$ & $\mathbf{x}$ & $\mathbf{x}$ & $\mathbf{C}$ & LC \\
\hline 96 & Montipora monasteriata (Forskål, 1775) & & $\mathrm{x}$ & $\mathrm{x}$ & $\mathrm{x}$ & $\mathbf{C}$ & LC \\
\hline 97 & Montipora nodosa (Dana, 1846) & & & $\mathrm{x}$ & & UC & NT \\
\hline 98 & Montipora palawanensis Veron, 2000 & & & $\mathrm{x}$ & & UC & NT \\
\hline 99 & Montipora peltiformis Bernard, 1897 & & & $\mathrm{x}$ & & UC & NT \\
\hline 100 & Montipora spumosa (Lamarck, 1816) & & & $\mathrm{x}$ & & $\mathbf{C}$ & LC \\
\hline 101 & Montipora stellata Bernard, 1897 & & & $\mathrm{x}$ & $\mathrm{x}$ & $\mathrm{C}$ & $\mathrm{LC}$ \\
\hline 102 & Montipora tuberculosa (Lamarck, 1816) & $\mathrm{x}$ & & $\mathbf{x}$ & $\mathbf{x}$ & $\mathbf{C}$ & LC \\
\hline
\end{tabular}




\begin{tabular}{|c|c|c|c|c|c|c|c|}
\hline No. & Scleractinian hard coral species & $\begin{array}{l}\text { Harborne } \\
\text { et al. } 2000\end{array}$ & $\begin{array}{l}\text { Affendi et } \\
\text { al. } 2005\end{array}$ & $\begin{array}{c}\text { Affendi et } \\
\text { al. } 2007\end{array}$ & $\begin{array}{l}\text { Present } \\
\text { Record }\end{array}$ & $\begin{array}{c}\text { Abundance } \\
\text { (COTW) }\end{array}$ & $\begin{array}{l}\text { IUCN Red } \\
\text { List }\end{array}$ \\
\hline 103 & Montipora turgescens Bernard, 1897* & & & & $\mathbf{x}$ & $\mathbf{C}$ & LC \\
\hline 104 & Montipora undata Bernard, 1897 & & & $\mathbf{x}$ & $\mathbf{x}$ & $\mathrm{C}$ & NT \\
\hline 105 & Montipora venosa (Ehrenberg, 1834) & & & $\mathbf{x}$ & $\mathbf{x}$ & UC & NT \\
\hline 106 & Montipora verrucolosus Veron, 2000 & & & $\mathrm{x}$ & $\mathbf{x}$ & UC & VU \\
\hline 107 & Montipora verrucosa (Lamarck, 1816) & & $\mathbf{x}$ & $\mathbf{x}$ & $\mathbf{x}$ & $\mathbf{C}$ & LC \\
\hline \multirow[t]{2}{*}{108} & Montipora vietnamensis Veron, 2000 & & & & $\mathrm{x}$ & UC & VU \\
\hline & \multicolumn{7}{|l|}{ Agariciidae Gray, 1847} \\
\hline 109 & Coeloseris mayeri Vaughan, $1918 *$ & & & & $\mathbf{x}$ & UC & $\mathbf{L C}$ \\
\hline 110 & Gardineroseris planulata (Dana, 1846) & $\mathrm{x}$ & $\mathrm{x}$ & $\mathrm{x}$ & $\mathbf{x}$ & UC & LC \\
\hline 111 & Leptoseris explanata Yabe \& Sugiyama, 1941 & $\mathrm{x}$ & & $\mathrm{x}$ & & UC & LC \\
\hline 112 & Leptoseris foliosa Dinesen, 1980 & & $\mathrm{x}$ & $\mathrm{x}$ & & UC & LC \\
\hline 113 & Leptoseris gardineri Van der Horst, 1921 & & $\mathrm{x}$ & & & UC & LC \\
\hline 114 & Leptoseris hawaiiensis Vaughan, 1907 & & $\mathrm{x}$ & & & $\mathbf{U C}$ & LC \\
\hline 115 & Leptoseris mycetoseroides Wells, 1954 & $\mathrm{x}$ & $\mathrm{x}$ & & $\mathbf{x}$ & $\mathbf{C}$ & $\mathbf{L C}$ \\
\hline 116 & Leptoseris papyracea (Dana, 1846) & $\mathrm{x}$ & $\mathrm{x}$ & & & $\mathbf{U C}$ & $\mathbf{L C}$ \\
\hline 117 & Leptoseris scabra Vaughan, 1907 & $\mathrm{x}$ & $\mathrm{x}$ & $\mathbf{x}$ & $\mathbf{x}$ & UC & LC \\
\hline 118 & Leptoseris tubulifera Vaughan, 1907 & & $\mathrm{x}$ & & & $\mathbf{U C}$ & LC \\
\hline 119 & Leptoseris yabei (Pillai \& Scheer, 1976) & & $\mathrm{x}$ & & & $\mathrm{UC}$ & VU \\
\hline 120 & Pavona bipartite Nemenzo, 1979 & $\mathrm{x}$ & & $\mathrm{x}$ & & UC & VU \\
\hline 121 & Pavona cactus (Forskål, 1775) & $\mathrm{x}$ & $\mathrm{x}$ & $\mathrm{x}$ & $\mathrm{x}$ & $\mathrm{C}$ & VU \\
\hline 122 & Pavona clavus (Dana, 1846) & $\mathbf{x}$ & $\mathbf{x}$ & $\mathbf{x}$ & $\mathbf{x}$ & $\mathbf{C}$ & LC \\
\hline 123 & Pavona danai Milne Edwards \& Haime, 1860 & & & $\mathrm{x}$ & $\mathrm{x}$ & $\mathrm{UC}$ & VU \\
\hline 124 & Pavona decussata (Dana, 1846) & $\mathbf{x}$ & $\mathbf{x}$ & $\mathbf{x}$ & $\mathbf{x}$ & $\mathbf{C}$ & VU \\
\hline 125 & Pavona duerdeni Vaughan, 1907 & & $\mathrm{x}$ & & & $\mathrm{UC}$ & $\mathrm{LC}$ \\
\hline 126 & Pavona explanulata (Lamarck, 1816) & $\mathbf{x}$ & $\mathbf{x}$ & $\mathbf{x}$ & $\mathbf{x}$ & $\mathbf{C}$ & $\mathbf{L C}$ \\
\hline 127 & Pavona frondifera (Lamarck, 1816) & & $\mathrm{x}$ & $\mathrm{x}$ & $\mathrm{x}$ & $\mathbf{C}$ & LC \\
\hline 128 & Pavona gigantea Verrill, 1869 & & & $\mathrm{x}$ & & UC & LC \\
\hline 129 & Pavona maldivensis (Gardiner, 1905) & & $\mathrm{x}$ & & & $\mathbf{C}$ & LC \\
\hline 130 & Pavona venosa (Ehrenberg, 1834) & & $\mathrm{x}$ & & $\mathbf{x}$ & $\mathbf{U C}$ & VU \\
\hline \multirow[t]{2}{*}{131} & Pavona varians Verrill, 1864 & $\mathrm{x}$ & & $\mathrm{x}$ & $\mathrm{x}$ & $\mathrm{C}$ & $\mathrm{LC}$ \\
\hline & \multicolumn{7}{|l|}{ Astrocoeniidae Koby, 1890} \\
\hline 132 & Palauastrea ramosa Yabe \& Sugiyama, 1941 & & $\mathrm{x}$ & & & $\mathbf{C}$ & NT \\
\hline 133 & Stylocoeniella armata (Ehrenberg, 1834) & & & $\mathrm{x}$ & & $\mathbf{R}$ & $\mathbf{L C}$ \\
\hline 134 & Stylocoeniella cocosensis Veron, 1990 & & & $\mathrm{x}$ & & $\mathbf{R}$ & $\mathbf{V U}$ \\
\hline \multirow[t]{2}{*}{135} & Stylocoeniella guentheri (Bassett-Smith, 1890) & $\mathrm{x}$ & & & $\mathrm{x}$ & $\mathrm{UC}$ & $\mathrm{LC}$ \\
\hline & Coscinaraeidae Benzoni, Arrigoni, Stefani \& Stolarski, 2012 & & & & & & \\
\hline 136 & Coscinaraea columna (Dana, 1846) & $\mathrm{x}$ & & & $\mathbf{x}$ & $\mathbf{C}$ & LC \\
\hline 137 & Coscinaraea exesa (Dana, 1846) & $\mathrm{x}$ & & $\mathbf{x}$ & $\mathbf{x}$ & $\mathbf{C}$ & LC \\
\hline \multirow[t]{2}{*}{138} & Coscinaraea hahazimaensis Yabe \& Sugiyama, 1936 & $\mathrm{x}$ & & & & $\mathrm{R}$ & VU \\
\hline & \multicolumn{7}{|l|}{ Dendrophylliidae Gray, 1847} \\
\hline 139 & Turbinaria frondens (Dana, 1846) & & & & $\mathbf{x}$ & $\mathbf{C}$ & LC \\
\hline 140 & Turbinaria irregularis Bernard, 1896 & $\mathrm{x}$ & & & $\mathbf{x}$ & $\mathbf{C}$ & LC \\
\hline 141 & Turbinaria mesenterina (Lamarck, 1816) & $\mathrm{x}$ & & $\mathrm{x}$ & $\mathbf{x}$ & $\mathbf{C}$ & $\mathbf{V U}$ \\
\hline 142 & Turbinaria peltata (Esper, 1794) & $\mathrm{x}$ & & & $\mathbf{x}$ & $\mathbf{C}$ & VU \\
\hline 143 & Turbinaria reniformis Bernard, 1896 & & & $\mathrm{x}$ & $\mathrm{x}$ & $\mathrm{C}$ & VU \\
\hline \multirow[t]{2}{*}{144} & Turbinaria stellulata (Lamarck, 1816) & $\mathrm{x}$ & $\mathrm{x}$ & $\mathrm{x}$ & $\mathrm{x}$ & UC & VU \\
\hline & \multicolumn{7}{|l|}{ Diploastraeidae Chevalier \& Beauvais, 1987} \\
\hline \multirow[t]{2}{*}{145} & Diploastrea heliopora (Lamarck, 1816) & $\mathrm{x}$ & $\mathrm{x}$ & $\mathrm{x}$ & $\mathrm{x}$ & $\mathrm{C}$ & NT \\
\hline & \multicolumn{7}{|l|}{ Euphylliidae Alloiteau, 1952} \\
\hline 146 & Euphyllia ancora Veron \& Pichon, 1980 & $\mathrm{x}$ & $\mathrm{x}$ & $\mathrm{x}$ & $\mathrm{x}$ & UC & VU \\
\hline 147 & Euphyllia cristata Chevalier, 1971* & & & & $\mathbf{x}$ & UC & VU \\
\hline 148 & Euphyllia divisa Veron \& Pichon, 1980 & $\mathrm{x}$ & $\mathrm{x}$ & $\mathrm{x}$ & $\mathrm{x}$ & $\mathrm{UC}$ & NT \\
\hline 149 & Euphyllia glabrescens (Chamisso \& Eysenhardt, 1821) & $\mathrm{x}$ & & $\mathbf{x}$ & $\mathbf{x}$ & $\mathbf{U C}$ & NT \\
\hline 150 & Euphyllia paradivisa Veron, 1990 & & $\mathrm{x}$ & $\mathrm{x}$ & & UC & VU \\
\hline
\end{tabular}




\begin{tabular}{|c|c|c|c|c|c|c|c|}
\hline No. & Scleractinian hard coral species & $\begin{array}{l}\text { Harborne } \\
\text { et al. } 2000\end{array}$ & $\begin{array}{l}\text { Affendi et } \\
\text { al. } 2005\end{array}$ & $\begin{array}{c}\text { Affendi et } \\
\text { al. } 2007\end{array}$ & $\begin{array}{l}\text { Present } \\
\text { Record }\end{array}$ & $\begin{array}{c}\text { Abundance } \\
\text { (COTW) }\end{array}$ & $\begin{array}{c}\text { IUCN Red } \\
\text { List }\end{array}$ \\
\hline 151 & Euphyllia paraglabrescens Veron, 1990 & & $\mathrm{x}$ & & & $\mathbf{R}$ & $\mathbf{V U}$ \\
\hline 152 & Euphyllia yaeyamensis (Shirai, 1980) & $\mathrm{x}$ & & & $\mathbf{x}$ & UC & - \\
\hline 153 & Galaxea astreata (Lamarck, 1816) & $\mathrm{x}$ & $\mathrm{x}$ & $\mathbf{x}$ & $\mathbf{x}$ & $\mathbf{C}$ & $\mathbf{V U}$ \\
\hline 154 & Galaxea fascicularis (Linnaeus, 1767) & $\mathbf{x}$ & $\mathbf{x}$ & $\mathbf{x}$ & $\mathbf{x}$ & $\mathbf{C}$ & NT \\
\hline 155 & Galaxea horrescens (Dana, 1846) & & & $\mathrm{x}$ & & UC & LC \\
\hline 156 & Pachyseris foliosa Veron, 1990 & $\mathbf{x}$ & $\mathbf{x}$ & $\mathbf{x}$ & $\mathbf{x}$ & UC & $\mathbf{L C}$ \\
\hline 157 & Pachyseris gemmae Nemenzo, 1955 & & $\mathbf{x}$ & $\mathbf{x}$ & $\mathbf{x}$ & $\mathbf{R}$ & NT \\
\hline 158 & Pachyseris rugosa (Lamarck, 1801) & $\mathbf{x}$ & $\mathbf{x}$ & $\mathbf{x}$ & $\mathbf{x}$ & $\mathbf{C}$ & $\mathbf{V U}$ \\
\hline \multirow[t]{2}{*}{159} & Pachyseris speciosa (Dana, 1846) & $\mathrm{x}$ & $\mathrm{x}$ & $\mathrm{x}$ & $\mathrm{x}$ & $\mathrm{C}$ & $\mathrm{LC}$ \\
\hline & \multicolumn{7}{|l|}{ Fungiidae Dana, 1846} \\
\hline 160 & Ctenactis albitentaculata Hoeksema, 1989 & $\mathrm{x}$ & $\mathrm{x}$ & & $\mathbf{x}$ & $\mathbf{C}$ & NT \\
\hline 161 & Ctenactis crassa (Dana, 1846) & $\mathbf{x}$ & $\mathbf{x}$ & $\mathbf{x}$ & $\mathbf{x}$ & $\mathbf{U C}$ & $\mathbf{L C}$ \\
\hline 162 & Ctenactis echinata (Pallas, 1766) & $\mathbf{x}$ & $\mathbf{x}$ & $\mathbf{x}$ & $\mathbf{x}$ & $\mathbf{C}$ & LC \\
\hline 163 & Cycloseris costulata (Ortmann, 1889) & & $\mathbf{x}$ & $\mathbf{x}$ & $\mathbf{x}$ & $\mathbf{R}$ & $\mathbf{L C}$ \\
\hline 164 & Cycloseris distorta (Michelin, 1842) & $\mathrm{x}$ & $\mathrm{x}$ & & & UC & LC \\
\hline 165 & Cycloseris fragilis (Alcock, 1893) & $\mathrm{x}$ & & $\mathrm{x}$ & & UC & $\mathbf{L C}$ \\
\hline 166 & Cycloseris somervillei (Gardiner, 1909) & & & $\mathbf{x}$ & $\mathbf{x}$ & $\mathbf{U C}$ & $\mathbf{L C}$ \\
\hline 167 & Cycloseris tenuis (Dana, 1846) & & $\mathrm{x}$ & $\mathrm{x}$ & & $\mathbf{R}$ & LC \\
\hline 168 & Cycloseris vaughani (Boschma, 1923) & & $\mathrm{x}$ & $\mathrm{x}$ & & $\mathbf{R}$ & LC \\
\hline 169 & Danafungia horrida (Dana, 1846) & & $\mathbf{x}$ & $\mathbf{x}$ & $\mathbf{x}$ & $\mathbf{C}$ & LC \\
\hline 170 & Danafungia scruposa (Klunzinger, 1879) & & & $\mathrm{x}$ & & UC & LC \\
\hline 171 & Fungia fungites (Linnaeus, 1758) & $\mathbf{x}$ & $\mathbf{x}$ & $\mathbf{x}$ & $\mathbf{x}$ & $\mathbf{C}$ & NT \\
\hline 172 & Heliofungia actiniformis (Quoy \& Gaimard, 1833) & $\mathrm{x}$ & $\mathrm{x}$ & $\mathrm{x}$ & $\mathbf{x}$ & $\mathbf{C}$ & VU \\
\hline 173 & Heliofungia fralinae (Nemenzo, 1955) & & $\mathrm{x}$ & & & UC & LC \\
\hline 174 & Herpolitha limax (Esper, 1797) & $\mathrm{x}$ & $\mathrm{x}$ & $\mathrm{x}$ & $\mathbf{x}$ & $\mathbf{C}$ & $\mathbf{L C}$ \\
\hline 175 & Lithophyllon concinna (Verrill, 1864) & $\mathrm{x}$ & & $\mathbf{x}$ & $\mathbf{x}$ & $\mathbf{C}$ & LC \\
\hline 176 & Lithophyllon repanda (Dana, 1846) & $\mathrm{x}$ & $\mathrm{x}$ & $\mathbf{x}$ & $\mathbf{x}$ & $\mathbf{C}$ & LC \\
\hline 177 & Lithophyllon scabra (Döderlein, 1901) & & $\mathbf{x}$ & $\mathbf{x}$ & $\mathbf{x}$ & $\mathbf{R}$ & LC \\
\hline 178 & Lithophyllon spinifer (Claereboudt \& Hoeksema, 1987) & & $\mathrm{x}$ & $\mathrm{x}$ & & $\mathbf{R}$ & $\mathbf{L C}$ \\
\hline 179 & Lithophyllon undulatum Rehberg, 1892 & $\mathbf{x}$ & $\mathbf{x}$ & $\mathbf{x}$ & $\mathbf{x}$ & $\mathbf{U C}$ & NT \\
\hline 180 & Lobactis scutaria (Lamarck, 1801) & & $\mathrm{x}$ & & $\mathbf{x}$ & $\mathbf{C}$ & $\mathbf{L C}$ \\
\hline 181 & Pleuractis granulosa (Klunzinger, 1879) & $\mathbf{x}$ & $\mathbf{x}$ & $\mathbf{x}$ & $\mathbf{x}$ & UC & LC \\
\hline 182 & Pleuractis gravis (Nemenzo, 1955) & & & & $\mathrm{x}$ & UC & - \\
\hline 183 & Pleuractis moluccensis (Van der Horst, 1919) & $\mathbf{x}$ & $\mathbf{x}$ & $\mathbf{x}$ & $\mathbf{x}$ & UC & LC \\
\hline 184 & Pleuractis paumotensis (Stutchbury, 1833) & $\mathrm{x}$ & $\mathrm{x}$ & $\mathbf{x}$ & $\mathbf{x}$ & $\mathbf{C}$ & $\mathbf{L C}$ \\
\hline 185 & Pleuractis seychellensis (Hoeksema, 1993)* & & & & $\mathbf{x}$ & UC & VU \\
\hline 186 & Podabacia crustacea (Pallas, 1766) & $\mathrm{x}$ & $\mathrm{x}$ & $\mathrm{x}$ & $\mathbf{x}$ & UC & LC \\
\hline 187 & Podabacia motuporensis Veron, 1990 & & $\mathrm{x}$ & & $\mathbf{x}$ & UC & NT \\
\hline 188 & Polyphyllia talpina (Lamarck, 1801) & $\mathrm{x}$ & $\mathrm{x}$ & $\mathrm{x}$ & $\mathbf{x}$ & $\mathbf{C}$ & LC \\
\hline 189 & Sandalolitha dentata Quelch, 1884 & & $\mathrm{x}$ & & $\mathbf{x}$ & UC & LC \\
\hline \multirow[t]{2}{*}{190} & Sandalolitha robusta (Quelch, 1886) & $\mathrm{x}$ & $\mathrm{x}$ & $\mathrm{x}$ & $\mathrm{x}$ & $\mathrm{C}$ & $\mathrm{LC}$ \\
\hline & \multicolumn{7}{|l|}{ Lobophylliidae Dai \& Horng, 2009} \\
\hline 191 & Acanthastrea brevis Milne Edwards and Haime, $1849^{*}$ & & & & $\mathbf{x}$ & UC & VU \\
\hline 192 & Acanthastrea echinata (Dana, 1846) & & & & $\mathrm{x}$ & $\mathrm{UC}$ & $\mathrm{LC}$ \\
\hline 193 & Acanthastrea hemprichi (Ehrenberg, 1834) & $\mathrm{x}$ & & & $\mathbf{x}$ & UC & VU \\
\hline 194 & Acanthastrea pachysepta Chevalier, 1975 & & $\mathbf{x}$ & $\mathbf{x}$ & $\mathbf{x}$ & UC & NT \\
\hline 195 & Acanthastrea rotundoflora Chevalier, 1975 & & & & $\mathbf{x}$ & UC & NT \\
\hline 196 & Acanthastrea subechinata Veron, 2000* & & & & $\mathbf{x}$ & UC & NT \\
\hline 197 & Echinophyllia aspera (Eillis \& Solander, 1786) & $\mathrm{x}$ & $\mathrm{x}$ & & $\mathrm{x}$ & $\mathrm{C}$ & $\mathrm{LC}$ \\
\hline 198 & Echinophyllia orpheensis Veron \& Pichon, 1980 & & $\mathrm{x}$ & & $\mathbf{x}$ & UC & $\mathbf{L C}$ \\
\hline 199 & Homophyllia australis (Milne Edwards \& Haime, 1849) & $\mathrm{x}$ & & $\mathbf{x}$ & $\mathbf{x}$ & UC & LC \\
\hline 200 & Lobophyllia agaricia Milne Edwards \& Haime, 1849 & $\mathbf{x}$ & $\mathbf{x}$ & $\mathbf{x}$ & $\mathbf{x}$ & UC & LC \\
\hline 201 & Lobophyllia corymbosa (Forskål, 1775) & & $\mathrm{x}$ & $\mathrm{x}$ & $\mathrm{x}$ & $\mathrm{C}$ & LC \\
\hline 202 & Lobophyllia diminuta Veron, 1985 & & & $\mathrm{x}$ & & UC & $\mathbf{V U}$ \\
\hline
\end{tabular}




\begin{tabular}{|c|c|c|c|c|c|c|c|}
\hline No. & Scleractinian hard coral species & $\begin{array}{l}\text { Harborne } \\
\text { et al. } 2000\end{array}$ & $\begin{array}{l}\text { Affendi et } \\
\text { al. } 2005\end{array}$ & $\begin{array}{c}\text { Affendi et } \\
\text { al. } 2007\end{array}$ & $\begin{array}{l}\text { Present } \\
\text { Record }\end{array}$ & \begin{tabular}{|c|}
$\begin{array}{c}\text { Abundance } \\
\text { (COTW) }\end{array}$ \\
\end{tabular} & \begin{tabular}{|c} 
IUCN Red \\
List
\end{tabular} \\
\hline 203 & Lobophyllia flabelliformis Veron, 2000 & & $\mathbf{x}$ & $\mathbf{x}$ & $\mathbf{x}$ & $\mathbf{U C}$ & $\mathbf{V U}$ \\
\hline 204 & Lobophyllia hassi Pillai \& Scheer, 1976 & & $\mathbf{x}$ & $\mathbf{x}$ & $\mathbf{x}$ & UC & $\mathbf{V U}$ \\
\hline 205 & Lobophyllia hataii Yabe, Sugiyama \& Eguchi, 1936 & $\mathbf{x}$ & $\mathbf{x}$ & $\mathbf{x}$ & $\mathbf{x}$ & UC & LC \\
\hline 206 & Lobophyllia hemprichii (Ehrenberg, 1834) & $\mathbf{x}$ & $\mathbf{x}$ & $\mathbf{x}$ & $\mathbf{x}$ & $\mathbf{C}$ & $\mathbf{L C}$ \\
\hline 207 & Lobophyllia radians Milne Edwards \& Haime, 1849 & $\mathrm{x}$ & $\mathrm{x}$ & $\mathrm{x}$ & $\mathbf{x}$ & $\mathbf{C}$ & LC \\
\hline 208 & Lobophyllia recta (Dana, 1846) & $\mathbf{x}$ & $\mathbf{x}$ & $\mathbf{x}$ & $\mathbf{x}$ & $\mathbf{C}$ & LC \\
\hline 209 & Lobophyllia robusta Yabe \& Sugiyama, 1936 & & $\mathrm{x}$ & $\mathbf{x}$ & $\mathbf{x}$ & $\mathbf{U C}$ & LC \\
\hline 210 & Lobophyllia valenciennesii Milne Edwards \& Haime, 1849 & & & $\mathbf{x}$ & $\mathbf{x}$ & $\mathbf{U C}$ & LC \\
\hline 211 & Lobophyllia vitiensis (Brüggemann, 1877) & $\mathrm{x}$ & $\mathrm{x}$ & $\mathbf{x}$ & $\mathbf{x}$ & UC & NT \\
\hline 212 & Micromussa diminuta Veron, 2000 * & & & & $\mathbf{x}$ & $\mathbf{C}$ & NT \\
\hline 213 & Micromussa lordhowensis Veron and Pichon, 1982 & $\mathrm{x}$ & & & $\mathbf{x}$ & $\mathbf{R}$ & $\mathbf{V U}$ \\
\hline 214 & Micromussa multipunctata Hodgson, 1985 & & & $\mathbf{x}$ & $\mathbf{x}$ & UC & $\mathbf{V U}$ \\
\hline 215 & Micromussa regularis Veron, 2000 & & & $\mathrm{x}$ & & UC & LC \\
\hline 216 & Oxypora crassispinosa Nemenzo, 1979 & $\mathrm{x}$ & & & & $\mathrm{C}$ & $\mathbf{L C}$ \\
\hline 217 & Oxypora glabra Nemenzo, 1959 & & & $\mathrm{x}$ & & $\mathbf{C}$ & LC \\
\hline \multirow[t]{2}{*}{218} & Oxypora lacera (Verrill, 1864) & $\mathrm{x}$ & & $\mathrm{x}$ & $\mathrm{x}$ & UC & VU \\
\hline & \multicolumn{7}{|l|}{ Merulinidae Verrill, 1865} \\
\hline 219 & Australogyra zelli (Veron, Pichon \& Wijsman-Best, 1977) & & & $\mathrm{x}$ & & UC & NT \\
\hline 220 & Astrea annuligera Milne Edwards \& Haime, 1849 & & & $\mathrm{x}$ & & $\mathbf{C}$ & LC \\
\hline 221 & Astrea curta Dana, 1846 & $\mathrm{x}$ & $\mathbf{x}$ & $\mathbf{x}$ & $\mathbf{x}$ & C & LC \\
\hline 222 & Coelastrea aspera (Verrill, 1866) & & $\mathbf{x}$ & $\mathbf{x}$ & $\mathbf{x}$ & $\mathbf{U C}$ & NT \\
\hline 223 & Coelastrea palauensis (Yabe \& Sugiyama, 1936) & & $\mathbf{x}$ & $\mathbf{x}$ & $\mathbf{x}$ & UC & VU \\
\hline 224 & Cyphastrea agassizi (Vaughan, 1907) & & $\mathrm{x}$ & $\mathrm{x}$ & & $\mathbf{C}$ & LC \\
\hline 225 & Cyphastrea chalcidicum (Forskål, 1775) & & $\mathrm{x}$ & $\mathbf{x}$ & $\mathbf{x}$ & UC & LC \\
\hline 226 & Cyphastrea japonica Yabe \& Sugiyama, 1932 & & & $\mathrm{x}$ & & $\mathbf{C}$ & LC \\
\hline 227 & Cyphastrea microphthalma (Lamarck, 1816) & & & $\mathrm{x}$ & $\mathrm{x}$ & $\mathbf{R}$ & $\mathbf{V U}$ \\
\hline 228 & Cyphastrea ocellina (Dana, 1846) & & $\mathrm{x}$ & & & $\mathbf{C}$ & LC \\
\hline 229 & Cyphastrea serailia (Forskål, 1775) & & $\mathrm{x}$ & & $\mathbf{x}$ & UC & NT \\
\hline 230 & Dipsastraea albida (Veron, 2000) & & & $\mathrm{x}$ & & UC & $\mathbf{L C}$ \\
\hline 231 & Dipsastraea amicorum (Milne Edwards \& Haime, 1849) & $\mathbf{x}$ & $\mathbf{x}$ & $\mathbf{x}$ & $\mathbf{x}$ & - & - \\
\hline 232 & Dipsastraea camrasensis (Latypov, 2013)* & & & & $\mathbf{x}$ & UC & VU \\
\hline 233 & Dipsastraea faviaformis Veron, 2000 & & $\mathrm{x}$ & & & $\mathbf{C}$ & LC \\
\hline 234 & Dipsastraea favus (Forskål, 1775) & & $\mathrm{x}$ & $\mathrm{x}$ & $\mathbf{x}$ & $\mathbf{C}$ & NT \\
\hline 235 & Dipsastraea helianthoides (Wells, 1954) & & $\mathbf{x}$ & $\mathbf{x}$ & $\mathbf{x}$ & UC & NT \\
\hline 236 & Dipsastraea lizardensis (Veron, Pichon \& Wijsman, 1977) & & & $\mathrm{x}$ & $\mathbf{x}$ & UC & NT \\
\hline 237 & Dipsastraea maritima (Nemenzo, 1971) & $\mathbf{x}$ & $\mathbf{x}$ & $\mathbf{x}$ & $\mathbf{x}$ & UC & NT \\
\hline 238 & Dipsastraea marshae (Veron, 2000) & & & $\mathrm{x}$ & & $\mathbf{C}$ & NT \\
\hline 239 & Dipsastraea matthaii (Vaughan, 1918) & & & $\mathbf{x}$ & $\mathbf{x}$ & UC & NT \\
\hline 240 & Dipsastraea maxima (Veron, Pichon \& Wijsman, 1977) & $\mathrm{x}$ & & $\mathrm{x}$ & $\mathbf{x}$ & UC & LC \\
\hline 241 & Dipsastraea pallida (Dana, 1846) & $\mathbf{x}$ & $\mathbf{x}$ & $\mathbf{x}$ & $\mathbf{x}$ & $\mathbf{R}$ & $\mathbf{V U}$ \\
\hline 242 & Dipsastraea rosaria (Veron, 2000) & & $\mathrm{x}$ & & $\mathbf{x}$ & $\mathbf{U C}$ & LC \\
\hline 243 & Dipsastraea rotumana (Gardiner, 1899) & & $\mathrm{x}$ & $\mathrm{x}$ & & $\mathbf{C}$ & NT \\
\hline 244 & Dipsastraea rotundata (Veron and Pichon, 1977) & & $\mathrm{x}$ & $\mathbf{x}$ & $\mathbf{x}$ & $\mathbf{C}$ & LC \\
\hline 245 & Dipsastraea speciosa (Dana, 1846) & & $\mathbf{x}$ & $\mathbf{x}$ & $\mathbf{x}$ & $\mathbf{C}$ & LC \\
\hline 246 & Dipsastraea truncatus (Veron, 2000) & & $\mathbf{x}$ & $\mathbf{x}$ & $\mathbf{x}$ & $\mathbf{R}$ & NT \\
\hline 247 & Dipsastraea vietnamensis (Veron, 2000) & & & $\mathbf{x}$ & $\mathbf{x}$ & $\mathbf{R}$ & NT \\
\hline 248 & Dipsastraea veroni (Moll \& Best, 1984) & $\mathrm{x}$ & & & $\mathbf{x}$ & UC & LC \\
\hline 249 & Echinopora gemmacea (Lamarck, 1816) & $\mathrm{x}$ & $\mathrm{x}$ & & $\mathbf{x}$ & UC & NT \\
\hline 250 & Echinopora horrida Dana, 1846 & $\mathrm{x}$ & $\mathrm{x}$ & & $\mathbf{x}$ & $\mathbf{C}$ & LC \\
\hline 251 & Echinopora lamellosa (Esper, 1795) & $\mathrm{x}$ & & $\mathbf{x}$ & $\mathbf{x}$ & $\mathbf{C}$ & NT \\
\hline 252 & Echinopora mammiformis (Nemenzo, 1959) & & $\mathrm{x}$ & $\mathrm{x}$ & & UC & NT \\
\hline 253 & Echinopora pacificus Veron, 1990 & $\mathrm{x}$ & $\mathrm{x}$ & & $\mathbf{x}$ & $\mathbf{C}$ & NT \\
\hline 254 & Favites abdita (Ellis \& Solander, 1786) & $\mathbf{x}$ & $\mathbf{x}$ & $\mathbf{x}$ & $\mathbf{x}$ & $\mathbf{R}$ & NT \\
\hline 255 & Favites acuticollis (Ortmann, 1889) & $\mathrm{x}$ & & $\mathrm{x}$ & $\mathrm{x}$ & UC & NT \\
\hline
\end{tabular}




\begin{tabular}{|c|c|c|c|c|c|c|c|}
\hline No. & Scleractinian hard coral species & $\begin{array}{l}\text { Harborne } \\
\text { et al. } 2000\end{array}$ & $\begin{array}{l}\text { Affendi et } \\
\text { al. } 2005\end{array}$ & $\begin{array}{c}\text { Affendi et } \\
\text { al. } 2007\end{array}$ & $\begin{array}{l}\text { Present } \\
\text { Record }\end{array}$ & $\begin{array}{c}\text { Abundance } \\
\text { (COTW) }\end{array}$ & $\begin{array}{c}\text { IUCN Red } \\
\text { List }\end{array}$ \\
\hline 256 & Favites chinensis (Verrill, 1866) & & $\mathbf{x}$ & $\mathbf{x}$ & $\mathbf{x}$ & $\mathbf{C}$ & NT \\
\hline 257 & Favites colemani (Veron, 2000) & & & $\mathrm{x}$ & $\mathrm{x}$ & $\mathbf{C}$ & NT \\
\hline 258 & Favites complanata (Ehrenberg, 1834) & & $\mathbf{x}$ & $\mathbf{x}$ & $\mathbf{x}$ & $\mathbf{C}$ & NT \\
\hline 259 & Favites flexuosa (Dana, 1846) & & $\mathrm{x}$ & $\mathrm{x}$ & $\mathbf{x}$ & $\mathbf{U C}$ & NT \\
\hline 260 & Favites halicora (Ehrenberg, 1834) & $\mathbf{x}$ & $\mathbf{x}$ & $\mathbf{x}$ & $\mathbf{x}$ & UC & NT \\
\hline 261 & Favites magnistellata (Chevalier, 1971) & $\mathrm{x}$ & & $\mathbf{x}$ & $\mathbf{x}$ & $\mathbf{R}$ & NT \\
\hline 262 & Favites melicerum (Ehrenberg, 1834) & & $\mathrm{x}$ & $\mathrm{x}$ & $\mathrm{x}$ & $\mathrm{UC}$ & NT \\
\hline 263 & Favites micropentagonus Veron, 2000 & & $\mathrm{x}$ & & $\mathbf{x}$ & UC & NT \\
\hline 264 & Favites paraflexuosus Veron, 2000 & & & $\mathbf{x}$ & $\mathbf{x}$ & $\mathbf{C}$ & LC \\
\hline 265 & Favites pentagona (Esper, 1794) & & $\mathbf{x}$ & $\mathbf{x}$ & $\mathbf{x}$ & UC & VU \\
\hline 266 & Favites spinosa (Klunzinger, 1879) & & & $\mathrm{x}$ & & $\mathbf{R}$ & NT \\
\hline 267 & Favites stylifera (Yabe \& Sugiyama, 1937) & & $\mathrm{x}$ & $\mathrm{x}$ & & UC & NT \\
\hline 268 & Favites valenciennesi (Milne Edwards \& Haime, 1849) & & $\mathbf{x}$ & $\mathbf{x}$ & $\mathbf{x}$ & $\mathbf{C}$ & LC \\
\hline 269 & Goniastrea edwardsi Chevalier, 1971 & $\mathrm{x}$ & $\mathbf{x}$ & $\mathbf{x}$ & $\mathbf{x}$ & UC & NT \\
\hline 270 & Goniastrea favulus (Dana, 1846) & $\mathrm{x}$ & & $\mathrm{x}$ & $\mathrm{x}$ & $\mathrm{UC}$ & NT \\
\hline 271 & Goniastrea minuta Veron, 2000 & & & $\mathbf{x}$ & $\mathbf{x}$ & $\mathbf{C}$ & $\mathbf{L C}$ \\
\hline 272 & Goniastrea pectinata (Ehrenberg, 1834) & $\mathrm{x}$ & $\mathrm{x}$ & $\mathrm{x}$ & $\mathrm{x}$ & $\mathbf{C}$ & $\mathbf{L C}$ \\
\hline 273 & Goniastrea retiformis (Lamarck, 1816) & $\mathbf{x}$ & $\mathbf{x}$ & $\mathbf{x}$ & $\mathbf{x}$ & $\mathbf{C}$ & NT \\
\hline 274 & Goniastrea stelligera (Dana, 1846) & $\mathrm{x}$ & & $\mathbf{x}$ & $\mathbf{x}$ & $\mathbf{C}$ & NT \\
\hline 275 & Hydnophora exesa (Pallas, 1766) & $\mathbf{x}$ & $\mathbf{x}$ & $\mathbf{x}$ & $\mathbf{x}$ & UC & NT \\
\hline 276 & Hydnophora microconos (Lamarck, 1816) & $\mathbf{x}$ & $\mathbf{x}$ & $\mathbf{x}$ & $\mathbf{x}$ & UC & LC \\
\hline 277 & Hydnophora pilosa Veron, $1985 *$ & & & & $\mathbf{x}$ & $\mathbf{C}$ & $\mathbf{L C}$ \\
\hline 278 & Hydnophora rigida (Dana, 1846) & $\mathbf{x}$ & $\mathbf{x}$ & $\mathbf{x}$ & $\mathbf{x}$ & $\mathbf{C}$ & NT \\
\hline 279 & Leptoria phrygia (Ellis \& Solander, 1786) & $\mathrm{x}$ & & $\mathrm{x}$ & $\mathrm{x}$ & UC & LC \\
\hline 280 & Merulina ampliata (Ellis \& Solander, 1786) & $\mathbf{x}$ & $\mathbf{x}$ & $\mathbf{x}$ & $\mathbf{x}$ & $\mathbf{C}$ & $\mathbf{L C}$ \\
\hline 281 & Merulina scabricula Dana, 1846 & $\mathrm{x}$ & & $\mathbf{x}$ & $\mathbf{x}$ & $\mathbf{C}$ & LC \\
\hline 282 & Mycedium elephantotus (Pallas, 1766) & $\mathrm{x}$ & $\mathrm{x}$ & $\mathrm{x}$ & & $\mathbf{U C}$ & NT \\
\hline 283 & Oulophyllia bennettae (Veron, Pichon \& Wijsman, 1977) & $\mathrm{x}$ & & $\mathbf{x}$ & $\mathbf{x}$ & UC & NT \\
\hline 284 & Oulophyllia crispa (Lamarck, 1816) & $\mathrm{x}$ & & $\mathrm{x}$ & $\mathrm{x}$ & $\mathrm{C}$ & LC \\
\hline 285 & Paragoniastrea australensis (Milne Edwards, 1857) & & & $\mathbf{x}$ & $\mathbf{x}$ & UC & NT \\
\hline 286 & Paragoniastrea russelli (Wells, 1954) & & $\mathrm{x}$ & $\mathrm{x}$ & $\mathrm{x}$ & $\mathrm{R}$ & VU \\
\hline 287 & Paramontastraea salebrosa (Nemenzo, 1959) & & $\mathrm{x}$ & $\mathrm{x}$ & & UC & VU \\
\hline 288 & Pectinia alcicornis (Saville-Kent, 1871) & $\mathrm{x}$ & $\mathrm{x}$ & $\mathrm{x}$ & $\mathrm{x}$ & $\mathbf{C}$ & VU \\
\hline 289 & Pectinia lactuca (Pallas, 1766) & $\mathbf{x}$ & $\mathbf{x}$ & $\mathbf{x}$ & $\mathbf{x}$ & UC & EN \\
\hline 290 & Pectinia maxima (Moll \& Best, 1984) & $\mathrm{x}$ & & & & $\mathbf{C}$ & NT \\
\hline 291 & Pectinia paeonia (Dana, 1846) & & $\mathbf{x}$ & $\mathbf{x}$ & $\mathbf{x}$ & $\mathbf{C}$ & NT \\
\hline 292 & Platygyra acuta Veron, 2000 & & $\mathrm{x}$ & $\mathrm{x}$ & $\mathbf{x}$ & UC & NT \\
\hline 293 & Platygyra carnosus Veron, 2000 & & $\mathrm{x}$ & & $\mathbf{x}$ & UC & LC \\
\hline 294 & Platygyra contorta Veron, $1990^{*}$ & & & & $\mathrm{x}$ & $\mathrm{C}$ & NT \\
\hline 295 & Platygyra crosslandi Matthai, 1928 & & $\mathbf{x}$ & $\mathbf{x}$ & $\mathbf{x}$ & $\mathbf{C}$ & LC \\
\hline 296 & Platygyra daedalea (Ellis \& Solander, 1786) & $\mathrm{x}$ & & $\mathrm{x}$ & $\mathrm{x}$ & UC & NT \\
\hline 297 & Platygyra lamellina (Ehrenberg, 1834) & $\mathbf{x}$ & $\mathbf{x}$ & $\mathbf{x}$ & $\mathbf{x}$ & UC & LC \\
\hline 298 & Platygyra pini Chevalier, 1975 & & $\mathrm{x}$ & $\mathbf{x}$ & $\mathbf{x}$ & UC & NT \\
\hline 299 & Platygyra ryukyuensis Yabe \& Sugiyama, 1936 & & & & $\mathbf{x}$ & $\mathbf{U C}$ & $\mathbf{L C}$ \\
\hline 300 & Platygyra sinensis (Milne Edwards \& Haime, 1849) & $\mathrm{x}$ & $\mathrm{x}$ & $\mathbf{x}$ & $\mathbf{x}$ & UC & NT \\
\hline 301 & Platygyra verweyi Wijsman-Best, 1976 & $\mathrm{x}$ & $\mathrm{x}$ & & $\mathbf{x}$ & $\mathbf{R}$ & VU \\
\hline 302 & Platygyra yaeyamaensis Eguchi \& Shirai, 1977 & & & $\mathbf{x}$ & $\mathbf{x}$ & UC & LC \\
\hline 303 & Scapophyllia cylindrica Milne Edwards \& Haime, 1849 & $\mathrm{x}$ & & & $\mathbf{x}$ & $\mathbf{R}$ & NT \\
\hline \multirow[t]{2}{*}{304} & Trachyphyllia geoffroyi (Audouin, 1826) & $\mathrm{x}$ & & $\mathrm{x}$ & $\mathrm{x}$ & $\mathrm{C}$ & - \\
\hline & \multicolumn{7}{|l|}{ Pocilloporidae Gray, 1842} \\
\hline 305 & Pocillopora acuta Lamarck, 1816* & & & & $\mathbf{x}$ & $\mathbf{C}$ & LC \\
\hline 306 & Pocillopora damicornis (Linnaeus, 1758) & $\mathbf{x}$ & $\mathbf{x}$ & $\mathbf{x}$ & $\mathbf{x}$ & - & - \\
\hline 307 & Pocillopora grandis Dana, 1846 & $\mathrm{x}$ & & $\mathrm{x}$ & & $\mathbf{C}$ & LC \\
\hline 308 & Pocillopora meandrina Dana, 1846 & $\mathrm{x}$ & & & $\mathbf{x}$ & $\mathbf{C}$ & LC \\
\hline
\end{tabular}




\begin{tabular}{|c|c|c|c|c|c|c|c|}
\hline No. & Scleractinian hard coral species & $\begin{array}{l}\text { Harborne } \\
\text { et al. } 2000\end{array}$ & $\begin{array}{l}\text { Affendi et } \\
\text { al. } 2005\end{array}$ & $\begin{array}{c}\text { Affendi et } \\
\text { al. } 2007\end{array}$ & $\begin{array}{l}\text { Present } \\
\text { Record }\end{array}$ & $\begin{array}{c}\text { Abundance } \\
\text { (COTW) }\end{array}$ & $\begin{array}{l}\text { IUCN Red } \\
\text { List }\end{array}$ \\
\hline 309 & Pocillopora verrucosa (Ellis \& Solander, 1786) & $\mathrm{x}$ & $\mathrm{x}$ & $\mathrm{x}$ & $\mathrm{x}$ & $\mathrm{C}$ & NT \\
\hline 310 & Stylophora pistillata Esper, 1797 & $\mathbf{x}$ & $\mathbf{x}$ & $\mathbf{x}$ & $\mathbf{x}$ & $\mathbf{C}$ & $\mathbf{L C}$ \\
\hline \multirow[t]{2}{*}{311} & Stylophora subseriata (Ehrenberg, 1834) & $\mathrm{x}$ & $\mathrm{x}$ & & $\mathrm{x}$ & $\mathrm{C}$ & NT \\
\hline & \multicolumn{7}{|l|}{ Poritidae Gray, 1842} \\
\hline 312 & Goniopora columna Dana, 1846 & & $\mathrm{x}$ & & $\mathbf{x}$ & $\mathbf{C}$ & $\mathbf{L C}$ \\
\hline 313 & Goniopora djiboutiensis Vaughan, 1907 & & $\mathbf{x}$ & $\mathbf{x}$ & $\mathbf{x}$ & UC & $\mathbf{L C}$ \\
\hline 314 & Goniopora fruticosa Saville-Kent, 1893 & & & $\mathrm{x}$ & & $\mathbf{C}$ & NT \\
\hline 315 & Goniopora lobata Milne Edwards \& Haime, 1860 & & $\mathrm{x}$ & $\mathbf{x}$ & $\mathbf{x}$ & UC & LC \\
\hline 316 & Goniopora norfolkensis Veron \& Pichon, 1982 & & $\mathrm{x}$ & & & UC & VU \\
\hline 317 & Goniopora planulata (Ehrenberg, 1834) & $\mathrm{x}$ & & & & $\mathrm{UC}$ & LC \\
\hline 318 & Goniopora somaliensis Vaughan, 1907 & & $\mathrm{x}$ & $\mathrm{x}$ & & $\mathbf{U C}$ & NT \\
\hline 319 & Goniopora stokesi Milne Edwards \& Haime, 1851 & & $\mathrm{x}$ & $\mathrm{x}$ & & $\mathbf{C}$ & LC \\
\hline 320 & Goniopora tenuidens (Quelch, 1886) & & $\mathrm{x}$ & & & $\mathbf{C}$ & NT \\
\hline 321 & Porites annae Crossland, 1952 & $\mathrm{x}$ & & $\mathbf{x}$ & $\mathbf{x}$ & $\mathbf{C}$ & VU \\
\hline 322 & Porites aranetai Nemenzo, 1955 & & & $\mathrm{x}$ & & $\mathbf{C}$ & VU \\
\hline 323 & Porites attenuata Nemenzo, 1955 & & $\mathrm{x}$ & $\mathrm{x}$ & & $\mathbf{C}$ & $\mathbf{L C}$ \\
\hline 324 & Porites australiensis Vaughan, 1918 & & & $\mathrm{x}$ & $\mathrm{x}$ & $\mathbf{C}$ & VU \\
\hline 325 & Porites cocosensis Wells, 1950 & & & $\mathrm{x}$ & & UC & VU \\
\hline 326 & Porites cumulatus Nemenzo, 1955 & & $\mathrm{x}$ & & & $\mathbf{C}$ & NT \\
\hline 327 & Porites cylindrica Dana, 1846 & $\mathrm{x}$ & $\mathbf{x}$ & $\mathbf{x}$ & $\mathbf{x}$ & $\mathbf{C}$ & NT \\
\hline 328 & Porites densa Vaughan, 1918 & & & $\mathbf{x}$ & $\mathbf{x}$ & $\mathbf{C}$ & NT \\
\hline 329 & Porites echinulata Klunzinger, 1879 & & & $\mathrm{x}$ & & UC & DD \\
\hline 330 & Porites evermanni Vaughan, 1907 & $\mathrm{x}$ & $\mathrm{x}$ & & & $\mathbf{C}$ & VU \\
\hline 331 & Porites horizontalata Hoffmeister, 1925 & $\mathrm{x}$ & $\mathrm{x}$ & & $\mathbf{x}$ & $\mathbf{C}$ & $\mathbf{L C}$ \\
\hline 332 & Porites lichen Dana, 1846 & & & & $\mathbf{x}$ & $\mathbf{C}$ & NT \\
\hline 333 & Porites lobata Dana, 1846 & & $\mathrm{x}$ & $\mathrm{x}$ & $\mathrm{x}$ & $\mathbf{C}$ & LC \\
\hline 334 & Porites lutea Milne Edwards \& Haime, 1851 & & $\mathbf{x}$ & $\mathbf{x}$ & $\mathbf{x}$ & UC & $\mathbf{L C}$ \\
\hline 335 & Porites mayeri Vaughan, 1918 & & & $\mathrm{x}$ & $\mathrm{x}$ & UC & LC \\
\hline 336 & Porites monticulosa Dana, 1846 & $\mathbf{x}$ & $\mathbf{x}$ & $\mathbf{x}$ & $\mathbf{x}$ & $\mathbf{C}$ & NT \\
\hline 337 & Porites murrayensis Vaughan, 1918 & & $\mathrm{x}$ & & $\mathbf{x}$ & UC & NT \\
\hline 338 & Porites negrosensis Veron, 1990 & & & $\mathrm{x}$ & & $\mathbf{C}$ & VU \\
\hline 339 & Porites nigrescens Dana, 1846 & $\mathrm{x}$ & $\mathrm{x}$ & $\mathrm{x}$ & $\mathbf{x}$ & $\mathbf{C}$ & $\mathbf{L C}$ \\
\hline 340 & Porites rus (Forskål, 1775) & $\mathbf{x}$ & $\mathbf{x}$ & $\mathbf{x}$ & $\mathbf{x}$ & $\mathbf{C}$ & LC \\
\hline 341 & Porites solida (Forskål, 1775) & $\mathrm{x}$ & & $\mathbf{x}$ & $\mathbf{x}$ & $\mathbf{R}$ & DD \\
\hline \multirow[t]{2}{*}{342} & Stylaraea punctata (Linnaeus, 1758) & & & $\mathrm{x}$ & & $\mathrm{C}$ & NT \\
\hline & \multicolumn{7}{|l|}{ Psammocoridae Chevalier \& Beauvais, 1987} \\
\hline 343 & Psammocora contigua (Esper, 1797) & $\mathrm{x}$ & & $\mathbf{x}$ & $\mathbf{x}$ & UC & NT \\
\hline 344 & Psammocora digitata Milne Edwards \& Haime, 1851 & $\mathrm{x}$ & $\mathrm{x}$ & $\mathrm{x}$ & $\mathbf{x}$ & UC & - \\
\hline 345 & Psammocora haimiana Edwards \& Haime, 1851 & & $\mathrm{x}$ & & $\mathbf{x}$ & UC & LC \\
\hline \multirow[t]{2}{*}{346} & Psammocora profundacella Gardiner, 1898 & $\mathrm{x}$ & & & $\mathrm{x}$ & $\mathrm{UC}$ & NT \\
\hline & \multicolumn{7}{|l|}{ Siderastreidae Vaughan \& Wells, 1943} \\
\hline \multirow[t]{2}{*}{347} & Pseudosiderastrea tayami Yabe \& Sugiyama, 1935 & $\mathrm{x}$ & & & $\mathrm{x}$ & $\mathrm{UC}$ & NT \\
\hline & \multicolumn{7}{|l|}{ Scleractinia Incertae sedis } \\
\hline 348 & Blastomussa wellsi Wijsman-Best, 1973 & $\mathrm{x}$ & & & & $\mathbf{R}$ & $\mathbf{V U}$ \\
\hline 349 & Leptastrea aequalis Veron, 2000 & & & & & $\mathbf{U C}$ & LC \\
\hline 350 & Leptastrea pruinosa Crossland, 1952 & $\mathrm{x}$ & $\mathrm{x}$ & & $\mathbf{x}$ & $\mathbf{C}$ & $\mathbf{L C}$ \\
\hline 351 & Leptastrea purpurea (Dana, 1846) & $\mathbf{x}$ & $\mathbf{x}$ & & $\mathbf{x}$ & UC & LC \\
\hline 352 & Leptastrea transversa Klunzinger, 1879 & & $\mathbf{x}$ & & $\mathbf{x}$ & $\mathbf{C}$ & VU \\
\hline 353 & Physogyra lichtensteini (Milne Edwards \& Haime, 1851) & & & & $\mathbf{x}$ & UC & NT \\
\hline 354 & Plerogyra sinuosa (Dana, 1846) & $\mathbf{x}$ & $\mathbf{x}$ & & $\mathbf{x}$ & UC & LC \\
\hline \multirow[t]{2}{*}{355} & Plesiastrea versipora (Lamarck, 1816) & $\mathrm{x}$ & & & $\mathrm{x}$ & $\mathrm{C}$ & VU \\
\hline & 355 species, 67 genera and 15 families & 157 & 204 & 248 & 254 & & \\
\hline
\end{tabular}

Note: * new scleractinian species records for the east coast of Peninsular Malaysia; COTW: 29 rare species; IUCN Red List: 86 vulnerable and 3 endangered species. 